\title{
DE SOEMBANEEZEN,
}

\author{
DOOR
}

DR. ALB. C. KRUYT.

Op Soemba bracht ik de maand September en de eerste dagen van October 1920 door. De tijd was te beperkt om Oost-Soemba te bezoeken, zoodat ik mijn onderzoek moest beperken tot Middenen West-Soemba. Het nadeel hiervan is niet zoo heel groot, omdat de menschen en hunne gewoonten in Oost-Soemba vrijwel overeenkomen met die van het Oostelijk deel van Midden-Soemba. Na het verschijnen van het bekende werk van den toenmaligen Controleur S. Roos ( $\ltimes$ Bijdrage tot de kennis van taal, land en volk op het eiland Soemba», Verh. Bat. Gen. deel 36), is het eenige dat van wezenlijk belang is voor de ethnografie van dit eiland, de opstellen, die de missionaire predikant D. K. Wielenga in het Zendingstijdschrift "De Macedoniër», en in het Tijdschrift van het Bataviaasch Genootschap en de Bijdragen van het Koninklijk Instituut heeft gepubliceerd.

De anteekeningen, die ik gedurende mijn verblijf op Soemba gemaakt heb, geef ik hier, zonder daarbij in eenige vergelijking te treden met een en ander dat vroeger reeds gepubliceerd is. Van het werk van anderen zal gebruik gemaakt worden, wanneer ik later zal spreken over de resultaten, waartoe mijn onderzoek mij heeft geleid. Dat ik nog zooveel bijeen heb kunnen vergaderen, heb ik te danken aan de hulp, die ik bij dit werk heb mogen ondervinden, in de eerste en voornaamste plaats van Ds. D. K. Wielenga, die mij op mijn tocht vergezelde, die meermalen mijn tolk was, en die mij met zijn groote kennis van het volk heeft gediend. Ten overvloede is hij zoo vriendelijk geweest, dit opstel door te lezen, en waar noodig de schrijfwijze en de beteekenis van de benamingen te verbeteren. Ik behoef niet te zeggen, dat hierdoor de waarde van het onderstaande zeer verhoogd wordt.

Een opgave te doen van al de bewoners van dit eiland, die 
mij hebben voorgelicht, is niet mogelijk. Het zijn er te veel, Onder hen treden enkelen naar voren, die zich in dit opzicht hebben onderscheiden. Ik noem hier den jongen vorst van Taboendoeng, en Oemboe Dong, het oudste, nu blinde hoofd van Anakala, de vriend van Ds. Wielenga.

Het eiland Soemba is in vele landschapjes ingedeeld, waaruit de oorspronkelijk democratische maatschappij der Soembaneezen nog blijkt. In het Westen is van deze democratie nog het meest overgebleven; in het Midden en Oosten heeft zij plaats gemaakt voor een vorstenregeering; die a priori gesproken niet uit het volk zelf kan zijn voortgesproten. Dit blijkt o.m. uit de omstandigheid, dat er in de rijkjes van Midden- en Oost-Soemba gewoonlijk twee machthebbenden zijn, van wie de een de bewaarder is van de relikwieën van den stamvader, den Marapoe, terwijl het andere vorstengeslacht de wereldlijke macht in handen heeft. Wielenga geeft hiervan een voorbeeld in het radjahuis van Melolo (de Mac. 1916, bl. 10-11). Daar is de radja van Watoe Pelitoe (een onderdeel van het landschap Melolo) de mindere of jongere, die van Palai Malamba (een ander onderdeel) de meerdere of oudere. Dit blijkt ook uit de keuze, die de hoofden van die twee geslachten moeten doen, wanneer zij zich eene hoofdgemalin nemen. Watoe Pelitoe moet haar nemen uit Palai Malamba, maar een telg uit dit laatste geslacht zoekt zijne hoofdvrouw uit het vorstengeslacht van Taboendoeng, dat zeker een van de oudste stamhuizen op Soemba is. Daaruit kunnen we weer besluiten, dat Melolo van uit Taboendoeng bevolkt is. Voor de troonsopvolging komt alleen in aanmerking de zoon geboren uit het huwelijk met de vrouw uit het oorspronkelijk stamland. Behalve de radja van Melolo, zijn het alleen nog die van Kanatang en Rende, die zich op deze wijze met het huis van Taboendoeng verbinden.

Maar ook in dit oude land wordt de onderscheiding in twee deelen gevonden, die zoo goed als geheel onafhankelijk van elkaar zijn. Een van die twee wordt erkend de oudste, de voornaamste te zijn, "de hoogste geestelijke macht, de vasthouder van den stam-marapoe». Wielenga maakt te recht de opmerking, dat dit verschijnsel waarschijnlijk moet worden verklaard uit de omstandigheid, "dat de een de oorspronkelijke bezetter, en dus bezitter van den grond is geworden, terwijl de ander als later aangekomen, met toestemming van den oudste, een gedeelte 
van het land ter woning kreeg, of wel zonder toestemming door de sterke hand zich een plaats veroverde. In beide gevallen bleef echter de oudste de bezitter van de geestelijke macht» (de Mac. 1916, bl. 34).

Als derde mogelijkheid noemt Wielenga "dat de oorspronkelijke bewoners geheel verdreven werden, zoodat er slechts flauwe sporen van overgebleven zijn». Als voorbeeld (misschien wel het eenige) noemt Wielenga het landschap Laura. Een afdeeling van Laura (dat vroeger niet aan zee maar in de bergen lag) Lètèna geheeten, verdreef de lieden van Loemboeng of Lombo, de oorspronkelijke bezitters des lands. Na dien tijd riep Lètèna zijn jongeren broeder Maradana en deelde met hem het veroverde land. Maar ik meen dat we hier eenvoudig met het gevolg van een binnenlandschen oorlog te doen hẹben, en dat een onderscheiding in een jonger en ouder hoofdengeslacht tot den tijd moet worden teruggebracht, toen vreemdelingen, die van over zee kwamen, zich op het eiland gingen vestigen. Wielenga wijst er nog op, dat de jongere vaak den oudere in macht ging overvleugelen, zooals dit in Melolo is gebeurd, en in Laura, waar nu Maradana het radjaschap bezit.

Ook in het Westen zijn alle landschappen in twee deelen verdeeld: Lamboja in Lamboja en Patijala; Laura in Maradana en Lètèna, "die van de vlakte, en die van de bergen"; Lauli bondo en Lali wawa dus: Lauli boven en Lauli beneden); Wajewa (eigenlijk: Weiwewa) in Bali omba en Bali loko; Kodi in Kodi bokoel en Kodi bengedo. Maar afgaande op de inlichtingen die ik kreeg, geloof ik dat deze landverdeeling in het Westen niet te maken heeft met "ouder" of "jonger», doch alleen een stam-onderscheiding is, zonder eenig gevolg voor het minder of meer in aanzien zijn van de hoofden dier verschillende deelen. Tegenwoordig wonen leden van die onderscheiden stammen door elkaar, wat vroeger wel minder het geval zal zijn geweest. We hebben dus de bewoners van die verschillende afdeelingen te houden voor afstammelingen van de oudste voorvaders, die misschien wel broers zijn geweest, zoodat in dezen zin wel te spreken zou zijn van ouderen en jongeren stam, maar niet in den zin van meer of minder voornaam. Dit blijkt ook nog hieruit, dat in Lamboja bijvoorbeeld een eigen broer van het regeerende hoofd bewaarder van den stam-marapoe is. Dat de bewoners van een kuststreek, zooals die van Lètèna in Laura zich machtiger 
voelen dan hun stamgenooten van Maradana, die in het binnenland verblijf houden, moet vooral worden toegeschreven aan het algemeen in Indië voorkomende verschijnsel, dat bergbewoners bang zijn voor kustbewoners, omdat deze gewoonlijk welvarender zijn en meer wereldkennis bezitten.

Dat in het Westen politiek en godsdienst niet zoo van elkaar gescheiden zijn als in het Oosten het geval is, blijkt mede hieruit, dat de hoofden daar ratoe heeten, een titel, die in het Oosten alleen aan iemand gegeven wordt, die geestelijke belangen te behartigen heeft. In 't Westen heet deze geestelijke, die de stamgoden, marapoe verzorgt, a roe (jongere broeder) marapoe. Deze behoeft niet te werken, maar wordt door de bevolking onderhouden: zij maakt ook zijne woning. Wij komen beneden nog op dezen waardigheidsbekleeder terug.

Voordat ik mijn aanteekeningen over de Soembaneezen geef, is het van belang te weten, of wij op dit eiland met één en hetzelfde volk te doen hebben. Op grond van de ethnografische gegevens, zouden wij daartoe wel mogen besluiten, want deze zijn in hoofdzaak in alle landschappen gelijk. Ook taalkundig is het Soembaneesche volk in engeren zin één. Op gezag van Wielenga kan Soemba taalkundig in twee deelen verdeeld worden: de grens loopt over Palamedo, Lawonda en Anakala. Maar de talen, die in beide deelen gesproken worden, verschillen alleen dialectisch van elkaar. (D. K. Wielenga, Vergelijkende Woordenlijst der verschillende dialecten op het eiland Soemba, en eenige Soembaneesche spreekwijzen. Verh. Bat. Gen. deel $61,5^{\mathrm{e}}$ stuk Inleiding.)

Opmerkelijk is, dat de twee groepen van dialecten in het Oosten samenvallen met de vereering der aardsvaders. De eene is Oemboe Waloe Mandokoe. Deze wordt te Wai Mbidi vereerd in een huis met één dakpaal (gewoonlijk zijn er vier). Uit de omstandigheid, dat alleen de vorsten en de groote vrijheeren daar mogen gaan offeren zou men opmaken dat deze marapoe niet de voorvader is van het heele volk, maar van de aanzienlijken onder hen, de overheerschende groep.

De tweede aartsvader is Oemboe Waloe Sasar, die te Woenga, in het landschap Napoe wordt vereerd.

Ook in West-Soemba bestaan twee taalgroepen: de eene omvat Memboro, Anakala en Wanoekaka, de andere Laura, Wajewa, Lauli, Lamboja en Kodi. Ook deze vier laatste hebben dezelfde Dl. 78. 
overlevering omtrent hun herkomst. De hoofdgod (of goden), die steeds aangeduid worden met Ina Kalada - Ama Kalada (d.i. grootmoeder - grootvader), in Kodi: Ina Matongoe - Ama Matongoe, (tongoe $=$ planten), lieten op den berg Jawila in Wajewa twee menschen uit den hemel neer: Oemboe Pati Mangasar en zijne vrouw. Ze kregen mede: een paar buffels, een paar paarden, en nog andere dierenparen; daarbij een kokosboom, een pinangboom en een sirihrank. Van hieruit bevolkte dit eerste menschenpaar de genoemde landschappen. Een hunner eerste nederzettingen zou Tangðba in Wajewa zijn, waar nog oude graven worden gevonden.

De overgang tusschen de beide dialecten-groepen in WestSoemba wordt in Memboro gevonden. In dat landschap zegt Wielenga "vindt men tal van woorden, waarvan men de stammen in de Oostelijke dialecten tevergeefs zal zoeken. Wijst dit soms op een oer-Soembanees, terwijl door immigratie later een tweede "Taal» zich heeft ingeburgerd? Waar Wielenga dus eerst uit de verschijnselen, die bij de vorstengeslachten worden opgemerkt, tot de onderstelling komt, dat een vreemd volk een sterken invloed op het oorspronkelijke volk der Soembaneezen moet hebben uitgeoefend, komt hij hier langs taalkundigen weg tot hetzelfde vermoeden. Wielenga noemt het "opmerkelijk", dat het Savoeneesch meer verwant is aan de taal van Westelijk Soemba dan aan die van het Oosten van dit eiland, hoewel Savoe tot de laatst genoemde landstreek veel meer in betrekking stond o. a. door kolonisatie. Maar deze kolonisatie is pas van de laatste 60 jaar, en deze tijd is te kort om daarvan reeds invloed te mogen verwachten op de taal. Het door Wielenga genoemde verschijnsel zal wel zób́ moeten worden verklaard: Soembaneezen en Savoeneezen zijn twee stamverwante volken. De invloed der immigranten heeft zich op Oost-Soemba veel sterker doen gelden dan op het Westelijk deel van dit eiland, en daardoor zijn de menschen in het Oosten veel meer van het oorspronkelijke Savoeneesch-Soembaneesche type afgebracht dan in het Westen.

Trouwens de overlevering zelf wijst er op, dat de immigranten zich het eerst en zeker het stevigst in Oost-Soemba hebben vastgezet. Van Oemboe Waloe Mandokoe toch wordt verteld, dat hij met een vaartuig op Sasar, ongeveer in het midden van het eiland aankwam, en omdat hij daar reeds menschen vond, voer hij verder naar het Oosten, tot hij aan de monding van 
de Kambera-rivier kwam, en zich daar vestigde. Van Oemboe Waloe Sasar wordt medegedeeld, dat hij door oorlogen van Java verdreven werd, en in den hemel werd opgenomen om op het noordelijkste punt van het eiland, de pas genoemde kaap Sasar neer te dalen (Wielenga, Woordenlijst, bl. 3).

Vanwaar deze immigranten gekomen zijn? In de aanteekeningen, die hieronder volgen zullen enkele bijzonderheden voorkomen, die het niet te gewaagd maken daarvoor Bima ${ }^{1}$ aan te wijzen. In Wajewa hoorde ik o. a. het volgende verhaal: In den ouden tijd waren de Soembaneezen bevriend met de ana dawa kaka, "blanke vreemdelingen,, en met de ata ndima, Bimaneezen. Dezen kwamen over de steenen brug, die Kaap Sasar eertijds met de overzijde heet verbonden te hebben. De beide genoemde volken kwamen eens bij de Soembaneezen op een oogstfeest, en zooals de gewoonte is, werd daarbij aan "kuitschoppen» gedaan. Maar de vreemdelingen wonnen het, en vele Soembaneezen hadden gebroken beenen. Toen ging men over tot "vuistslaan", maar ook hierin moesten de Soembaneezen het tegen hun gasten afleggen, en het bloed stroomde hun langs het gezicht. Het eind was dat men elkaar ging uitschelden, waarna de ana dawa en de ata ndima aftrokken. Een tijd later vonden de Soembaneezen een grooten paling. Een man te paard werd nu over de steenen brug naar Bima gezonden om de menschen daar te roepen, opdat ze zouden komen om zich mede te goed te doen aan den paling. Maar het duurde zoo lang voordat de Bimaneezen kwamen, dat de Soembaneezen het dier opaten. Toen dan eindelijk de geroepenen kwamen, was de paling op. De Bimaneezen werden boos en er ontstond een hevig gevecht. Ten slotte besloot men toch maar vrede te maken, waarbij een gezamenlijke maaltijd zou worden gehouden. Maar bij die gelegenheid gaven de Soembaneezen aan de Bimaneezen vleesch te eten, «dat zij niet gewend waren te gebruiken» (misschien waren de Bimaneezen reeds Mohammedaan geworden, en wordt hier varkensvleesch bedoeld). De gasten keerden boos naar hun land terug. Ze zeiden tot hunne gastheeren: *Ge zult uw deel straks wel krijgen». Dit kregen deze laatste ook in een groote pokkenepidemie, die velen wegnam.

1 In Oostelijk Soemba noemt men de Westpunt van het eiland: la katikoe Tana Ndima: de kop van het land, Ndima, terwijl men zich zelf als de kikoe, de staart beschouwt.

W. 
In Laura leeft nog de herinnering voort, dat de menschen daar aan den Sultan van Bima belasting betaalden. Oost-Soemba schijnt zich veel eerder aan de overheersching van Bima onttrokken te hebben. Dat de Lauraërs een zooveel beschaafder indruk maken dan de overige Soembaneezen, dat hun vorsten veel meer te zeggen hebben, dan die der andere democratische landschappen, zal wel voor een deel moeten worden toegeschreven aan den langdurigen invloed, dien Bima daar heeft gehad. Wij mogen ook veilig aannemen, dat de immigranten zich in het Oosten en Midden veel meer met de bevolking hebben vermengd, dan in West-Soemba het geval is geweest, alleen met uitzondering van Kodi, aan de Westpunt des eilands, waar ook immigranten rechtstreeks geland moeten zijn.

De immigranten zijn waarschijnlijk inderdaad van Javaansche af komst geweest. Want Zollinger vertelt, dat tijdens de invoering van den Islam op Java vluchtelingen naar het Oosten trokken, en op Satonda aankwamen, de natuurlijke landingsplaats op den weg van Java. Maar een groot aantal menschen kon zich op den duur op dat eilandje niet staande houden, waarom ze naar den vasten wal van Soembawa overstaken, en zich in het vruchtbare landschap Dompo vestigden. De aanvoerder van deze immigranten moet Sang Bima hebben geheeten, en diens zonen zijn later de vorsten van Bima en Dompo geworden. Het is ook mogelijk dat Soemba reeds behoord heeft tot het Madja-pahitsche rijk onder Hayam Wuruk (1353-1388), maar in de lijst van de aan dit rijk onderhoorige eilanden wordt het niet genoemd (zie Indische Gids 1903, bl. 350).

Wat hier boven is gezegd stemt ook geheel overeen met de opmerkingen. die door kenners van het volk over het type worden gemaakt. In een verslag over Soemba van 1914 zegt de toenmalige Assistent-resident A. Couvreur: "Behoudens in de beide Kodi's komen bepaalde Hindoe-Javanen typen, zooals zoo vaak in Midden- en Oost-Soemba, in West-Soemba niet of weinig voor. Zonder hetzelfde sterk negroide aanzien te hebben van de bevolking van Flores of Timor, is dit type in WestSoemba toch niet onduidelijk kenbaar».

Van Memboro, dat zooals wij gezien hebben het overgangsgebied is tusschen Oost en West, zegt Dr. H. F. C. ten Kate reeds (Verslag eener Reis in de Timorgroep en Polinesië, bl. 197): *Niet alleen in kleeding, maar ook in type komen de Soemba- 
neezen van Memboro met die van het Oosten overeen. Het meerendeel is ook welgemaakt en krachtig. Korte rechte neuzen domineeren, vervolgens min of meer convexe. Ook hier vindt men sporadisch individuen met Semietische physionomieën, zoo veelvuldig onder de Savoeneezen. Anderen hebben weer een geheel Europeeschen gezichtsvorm, sommige zelfs met fijnbesneden gelaatstrekken .

De Heer Wielenga ${ }^{1}$ deelde mij mede, dat in Masoe (Taboendoeng) nog boschmenschen moeten voorkomen, tau omang geheeten. Ze zouden op primitieve manier met de andere menschen handeldrijven door wat zij willen verkoopen ergens neer te leggen, en zich dan te verwijderen; waarna degeen, die deze waren neemt, daarvoor wat anders in de plaats legt. Omtrent deze lieden ben ik niets anders te weten kunnen komen.

Marapoe. Over heel Soemba uit zich het geloof in de marapoe op dezelfde wijze. Alle onzichtbare machten, en de mediums, waardoor men ze tracht te benaderen, zijn marapoe. Al mijne pogingen om iets te vernemen van het hoogste wezen, dat hemel en aarde geschapen heeft, bleven vruchteloos. Wielenga schijft dan ook: "Een hoogste Wezen, dat alles geschapen heeft en onderhoudt, bestaat slechts in flauwe herinnering . Een eigen naam ${ }^{2}$ heeft men niet voor hem. Men zegt, "hij die menschen maakt, die menschen vlecht». Hoog boven de wolken troont hij in onbereikbare verhevenheid. Hij komt niet neder tot den mensch, en de mensch klimt niet tot hem op. Het wereldbestuur, het lot der menschen is niet zijn handen. Dit is overgelaten aan de mindere goden». (Mac. XIII, 1909, bl. 334).

De eigenlijke goden zijn de stamvaders. De naam duidt dit reeds aan want marapoe wil zeggen, zooals Wielenga heeft aangewezen, "die boven den haard wonen». Dat zijn de zielen der afgestorvenen, die daar hun verblijf houden, voordat zij naar het zielenland gaan. Het denkbeeld aan een zielenland is den Soembaneezen misschien nog door vreemdelingen bijgebracht, zooals nader zal blijken, wanneer ik over het leven na den dood zal spreken. Onder deze ma rapoe zijn de zielen der stamvaders

1 Het werd mij meer dan eens verteld, maar ik heb nooit zekerheid kunnen krijgen, zoodat het wel een legende zal zijn.

W.

- Een andere omschrijving van den allerhoogsten hemelheer is: pande pekoe tamoe, pande njoera ngara, dwz.: wiens naamgenoot niet bestaat en wiens naam niet is op te zoeken. In West Soemba: Ina Kalada-Ama Kalada, de groote moeder, de groote vader.

W. 
de voornaamste. Boven noemde ik reeds twee, die van vreemden oorsprong zijn, de marapoe van vorsten en grooten. Maar verder heeft ieder geslacht (kabisoe) zijn stamvader, marapoe. Deze wordt vereerd in kleine onoogelijke huisjes, die in WestSoemba in den kampong tusschen de huizen worden gevonden. De huizen van iederen kampong zijn om zulk een marapoe-hut heen gebouwd, zoodat gezegd kan worden, dat ieder dorp bewoond wordt door de afstammelingen van denzelfden marapoe. Een dorp is dus een kabisoe-schap.

In Midden-Soemba staan die hutjes soms afzonderlijk. Wielenga noemt er enkele op: te Batakapedoe in Kambera, te Palendi in Memboro, een te Mangili. De huisjes worden slecht onderhouden. Het is echter zaak te zorgen, dat er geen omvalt. Stortte het in, de wereld zou vergaan, de hemel zou invallen, en de aarde in stukken breken. (Mac. XIII, 1909, bl. 339).

In sommige dorpen van Midden-Soemba trof ik groote $\mathrm{ma-}$ rapoe-huizen aan, die door één gezin bewoond worden. De vader van dat gezin bewaakt de voorwerpen, die afkomstig zijn van dien stam-marapoe, die in West-Soemba in de pasgenoemde hutten zijn ondergebracht, maar hier nog «boven den haard, worden bewaard. Bij den nok is daartoe tusschen de vier hoofdpalen van het huis, juist boven den haard, een vliering aangebracht; daar bevinden zich de voorwerpen, die bij verschillende gelegenheden dienst moeten doen om met de marapoe in verbinding te komen. Geen onbevoegde mag naar die vliering opklimmen, of in de marapoe-hut van het Westen doordringen.

Deze marapoe-huizen worden soms (vooral in het Oosten) oema la andoeng "huis bij de andoeng» genoemd. ${ }^{1}$ De andoeng is een staak, die op het dorpsplein is opgericht, en waaraan de gesnelde hoofden werden opgehangen. Beneden kom ik hierop terug. Een enkele maal zegt men ook oema a n a moe, "het huis van de kuikens», naar aanleiding van de houten vogels (hanen), die op den nok zijn gestoken. ${ }^{2}$ De bewaker die in dit marapoe-huis woont heet: ta u matoetoe o ema, "degeen die op 't huis past». Deze mag nooit buitens-

1 In sommige dorpen maakt men onderscheid tusschen oema andoeng en o ema marapoe.

W.

2 Ana manoe (kippetje) is de gewone figuurlijke uitdrukking voor elk beest, dat geslacht wordt als offerande. Oema ana manoe is dus een omschrijving van het marapoe-huis als plaats van te brengen offers.

W. 
huis slapen, maar moet 's nachts altijd bij de marapoe zijn. Men vertelde mij te Lewa Pakoe, dat wanneer iemand iets gedaan had, waarvoor hij gedood zou worden, en hij vluchtte in het marapoe-huis, zijn leven dan niet meer genomen mocht worden. Wanneer er een groot feest gevierd wordt komen de rato e's, "geestelijke heeren, (over wie beneden nader), de aanzienlijken en het volk daar te zamen, en eten er, wanneer eerst op gewone wijze is gebeden en geofferd. Er wordt daarbij op gongs en trommen geslagen om de geesten te roepen, en twee lieden (de ratoe en de huisbewaarder) klimmen naar boven op het zoldertje, waar het medium bewaard wordt, om er goudschilfers als hulde neer te leggen. Het mandje waarin het offer van rijst voor de marapoe bij de hoofdpaal wordt gezet, heet mbola kawoenga, "de eerste (oorspronkelijke) mand,. Zoo ook heet de pot, waarin die rijst voor de marapoe gekookt is: woeroeng kawoenga, "eerste (oorspronkelijke) pot». Na afloop van de plechtigheid worden deze twee voorwerpen weggezet, en voor een volgende offergelegenheid bewaard: ze mogen niet voor dagelijksche doeleinden worden gebruikt.

$\mathrm{Bij}$ verschillende gelegenheden worden offerfeesten in het marapoe-huis gehouden: $\mathrm{Na}$ afloop van den oogst; wanneer de vorst een reis zal gaan ondernemen; wanneer men uit zal trekken om koppen te gaan snellen; wanneer een belangrijke zaak van bloedschande of overspel wordt berecht. Te Lewa Pakoe werden we rondgeleid door Oemboe Windi, den zoon van den radja van Lewa. Hij vertelde ons dat hij nog niet in het marapoehuis van zijn vader mocht komen. De reden hiervan is, omdat zijn moeder een prinses van Kanatang is, voor wie de bruidsschat nog niet is afbetaald, zoodat zij nog niet naar de woning van haar man is overgebracht. Men heeft eerbied voor dit marapoe-huis; in gewone tijden durft men er zelfs niet te dicht bij te komen.

In de oema marapoe mag alle soort van vleesch gebracht worden, dat men gewoon is te eten, ook dat van honden. Alleen is daar verboden op de joengga, een soort guitaar te spelen. Te Langgaliroe (Lakoka) mag in het marapoe-huis geen hondevleesch gebracht worden, omdat noch de radja, noch de ratoe dit eten, alleen omdat het hun tegen staat. Ook lipi, eene groentesoort, en $i w i$, oebi, mogen daar niet binnen gebracht worden; hili, Colocasia, daarentegen wel. 
Terwijl men bezig is tot de marapoe te bidden, mag niemand in de deuropening komen, waarschijnlijk met de gedachte, dat aan de geesten den weg niet versperd mag worden. In Lewa Pakoe staan bij zulk een gelegenheid twee mannen bij de deur, die met rotans gewapend zijn om voor de handhaving van dit verbod te waken.

Voor Midden-Soemba heeft Wielenga het marapoe-medium beschreven als een mandje of kistje, waarvan men den inhoud niet kent. Het is met koperdraad stevig vastgebonden, en niemand durft het openmaken om te zien wat er in zit. Zoo dichtgebonden is het overgeleverd van geslacht op geslacht, en het is zelfs streng verboden het te openen (Mac. XIII, bl. 337). In de marapoe-hutten van het Westen worden allerlei oude voorwerpen bewaard. De bronzen bijlen en de steenen hamers, afkomstig uit Midden- Celebes, die ik daar liet zien, werden dadelijk herkend als marapoe-voorwerpen. Lansen en zwaarden behọoren ook daartoe.

$\mathrm{R}$ at o e. Zooals reeds gezegd is wordt de stam-marapoe bewaakt door een persoon uit de voornaamsten des lands: deze waardigheid is erfelijk. De bewaker leidt de plechtigheden, hij is het die de marapoe aanroept; bij droogte vraagt hij om regen, bij de nadering van ziekte om afwending van het gevaar. Hij ook geeft uitsluitsel in kwesties van bloedverwantschap of erfenis. In gewichtige geschillen over den adat moet hij dikwijls den doorslag geven, en geen besluit is "rechtsgeldig dan wanneer de vorst hem er eerst in gekend heeft, en de ratoe er zijn goedkeuring namens de marapoe aan gehecht heeft. Van sommige ratoe's zegt men zelfs dat de marapoe in hem woont, zich op zijn schouders heeft neergezet (Mac. XII, bl. 370-371). Van alle aangelegenheden in het land is hij het beste op de hoogte, want hij heeft ze van zijn vader vernomen, en wanneer hij komt te sterven, heeft hij zijn kennis reeds aan zijn zoon overgeleverd. In West-Soemba komt het wel voor dat het landshoofd zelf als bewaker van de marapoe optreedt.

Dat deze ratoe het oorspronkelijke hoofd des volks is geweest, blijkt ook nog hieruit, dat hij de mangoe tana, de bezitter van den grond is, en niet de radja. Dit geldt voor Oost- en Midden-Soemba, waar de vorsten waarschijnlijk afsțammelingen zijn van vreemde usurpators. In het Westen heb ik niet vernomen, dat de ratoe's, de bewakers van de marapoe, ook eigenaars 
van den grond zijn; daar zijn het de radja's zelven. Wel verleenen de aroe marapoe daar natuurlijk hun diensten om de marapoe gunstig voor den landbouw te stemmen. Couvreur zegt in zijn bovengenoemd verslag: "Hij (de ratoe in Oost- en MiddenSoemba) heeft het beschikkingsrecht over den grond. Wil men ergens een tuinhuis opzetten of grond ontginnen, onder het brengen van een offerande aan den Ratoe voor de marapoe, dan vraagt men daartoe zijn toestemming, niet die van den maramba (radja), die buiten deze aangelegenheid staat.»

In Lakoka zijn drie ratoe's: Kabisoe Lakoka, a na matjoea, en ana ma'ari of toloe mata wai maringoe, thet rauwe vleesch en het koele water». De ana matjoea bewaakt de kabala. Kabala is de bliksem, die belichaamd is in een steen, die zich ergens in de wildernis bevindt. Wanneer het begint te donderen, verzamelen de menschen zich in zijn huis; wanneer het gewas door muizen of andere dieren dreigt vernield te worden, is hij het die offert en bidt. De eerste bos rijst die men op den akker heeft geoogst, is voor den ratoe. (Er zijn ook andere menschen die beweren macht te hebben over den bliksem. Wanneer bijvoorbeeld iemand gestolen heeft, en men weet niet wie de dief is, dan vraagt degeen die macht heeft over den bliksem aan dezen om den man te treffen, en dit gebeurt dan ook). De ratoe die den titel voert van an a ma'ari, zorgt ook wel voor regen, maar zijn hoofdwerk is toch het ontzondigen der menschen in gevallen van overspel en bloedschande. Vroeger wanneer men uit den strijd terugkwam, was hij het die de strijders ontsmette van het kwaad dat hun uit den oorlog aankleefde. ${ }^{1}$

Zooals gezegd is, krijgt de ratoe zijn levensonderhoud van de bevolking, d.w.z. ieder geeft hem een klein deel van de opbrenst van zijn akker. Maar het kan niemand verwonderen, wanneer de ratoe een armelijk bestaan lijdt, want de pas genoemde inkomsten zullen niet rijkelijk vloeien. Onder deze ratoe's zijn er, die veel invloed hebben, omdat ze alle omstandigheden in de Soemba-

1 Het landsohap Lakoka is niet een afzonderlijk landschap, als bv. Napoe Memboro en dgl. Het is een uitzwerming van Napoe, dat in twee marapoegeslachten is verdeeld, nl. an a matjoea en ana ma'ari (de oudere en de jongere broeder).

$\mathrm{Nu}$ bewakt ana matjoea de marapoe $\mathrm{kabala}$, terwijl ana ma'ari het zeggenschap heeft over de marapoe toloe mata, wai maringoe.

Deze marapoe is dus geen stamvader, maar een machtige geest of halfgod, de verzoener van alle schuld.

W. 
neesche maatschappij kennen, en altijd in de gelegenheid zijn te intrigeeren. Het moet dan ook wel eens zijn voorgekomen, dat een ratoe te veel macht en invloed kreeg, en dan liet de vorst hem uit den weg ruimen, om 's mans zoon in zijne plaats te stellen.

Behalve de stam-marapoe zijn er ook familie-marapoe en gezinsmarapoe. Het medium om met dezen in aanraking te komen bevindt zich in elke woning; het bestaat uit een kleiner mandje dan waarmee verbinding wordt gezocht met de stam-marapoe. Dit voorwerp maakt men zelf wanneer men het huis bouwt. Veel bijzonders bevindt er zich niet in. Het dient alleen als middel tot gemeenschap met de zielen der afgestorvenen, welke men onderstelt, dat daarin verblijf houden, en vandaar uit het wel en het wee der levenden besturen. Zooals gezegd is wordt dit mandje bewaard op een zoldertje bij den nok van het huis boven den haard. Wielenga doet in zijn belangrijke mededeelingen in het Zendingstijdschrift de Macedoniër een verhaal van zekeren Oemboe Ndiloe (in Oost-Soemba): deze huwt met een meisje dat uit een meloen komt. De vrouw wordt geroofd door een vogel, maar met de hulp van een aap en van duiven wordt zij teruggehaald. De aap krijgt tot belooning wat kiezelsteenen die hij bij een mensch deponeert. Deze steenen worden de marapoe voor de menschen van Karanggoe Watoe, die geen apen en duiven mogen dooden (XV, 1911).

Wanneer men de hulp van de marapoe wil inroepen, ten einde in een rechtszaak de overwinning te behalen, of om op reis zijn hulp te erlangen, of om gunstig weer te krijgen voor den aanplant, dan wordt het offer daartoe op een rekje van bamboe met pinanglatjes belegd, geplaatst. Dit rekje heet jarang in Midden-Soemba. Het bevindt zich steeds rechts boven den ingang van de woning. Het hoen dat voor deze plechtigheid bestemd is, wordt onder de jarang geslacht. Men onderstelt dat de marapoe-geest zich over dag op dat rekje ophoudt, vanwaar hij het leven van de menschen gade slaat. Van de jarang af neemt de marapoe deel aan de besprekingen over belangrijke aangelegenheden, het bepalen van den bruidsschat, het vellen van een vonnis, het nemen van een besluit. Wanneer de lever van een bij zulk een een gelegenheid geslacht varken wordt onderzocht, geschiedt dit met de bedoeling om na te gaan, of de marapoe het met de genomen beslissing eens is. Als onderpand daarvan wordt het kinnebak van het dier bij de jarang opgehangen. 
Van de geslachte hoenders worden de veeren er naast in het dak gestoken.

In Kambera en Lewa worden bij de onderhandeling over den bruidsschat vooraf twee gouden oorhangers, mamoeli, op de jarang gelegd, en deze dragen den naam van "oogen van Marapoe», opdat hij goed zal toekijken wat gegeven wordt. Die coogens worden na afloop der besprekingen weer opgeborgen. Wanneer men wil gaan oogsten geeft men daarvan vooraf kennis aan Marapoe op de jarang. Na afloop van den oogst wordt een klos mais met schil en al gekookt; is hij gaar, dan trekt men de schil er af, en wordt de vrucht in een mandje op de jarang gezet. Rijst mag in geen enkelen vorm op dit rekje komen, maar deze wordt bij den hoofdpaal der woning den geesten aangeboden. Op deze offers bij den landbouw kom ik later uitvoeriger terug, wanneer ik over dit onderwerp spreek.

In West-Soemba wordt geen jarang gevonden, maar daarvoor in de plaats heeft men een ronde plank als een kraag om den hoofdpaal bevestigd, waarop een en ander wordt gelegd dat men den geesten wil wijden.

Ik zeide reeds dat de menschen in Laura meer ontwikkeld zijn dan de overige Soembaneezen. Men houdt er daar eer een soort van theologie op na, waarvan ik elders niets heb gevonden. $\mathrm{Nu}$ is het natuurlijk de vraag of die meer ontwikkelde godsdienstige begrippen alleen het eigendom zijn van mijn zegslieden, en het volk daarvan weinig weet. In elk geval heb ik in den marapoe-dienst in Laura geen onderscheid gevonden met dien in andere landschappen van Soemba.

In Laura dan onderscheidt men twee soorten ${ }^{1}$ van marapoe:

1 Ook in geheel Oostelijk Soemba maakt men deze onderscheiding van marapoe maloeri (levende marapoe) en marapoe mameti (doode marapoe). De laatste categorie zijn de zielen der afgstorvenen. Ieder die sterft wordt wordt een marapoe mameti. Maar marapoe maloeri zijn de geesten in het algemeen. Zoo heeft men de marapoe tana, de marapoe awang, de marapoe ndjara, de maparoe manoe, de marapoe kabala, de marapoe maringoe wai, etc. etc. (de marapoe van den grond, van de lucht, van de paarden, van de kippen, van het onweder, van het koele water.

Het woord marapoe wordt in drieërlei beteekenis gebruikt. Het duidt aan de geesten en goden, de zielen der afgestorvenen en dan in bijvoegelijke beteekenis: aan geesten en zielen gewijd. Een marapoe oema is de beschermgeest van het huis, maar oema marapoe is: een huis waar men aan de marapoe offert.

W. 
levende marapoe, die ook in hun oorsprong geesten zijn geweest, en doode marapoe, de zielen van afgestorvenen. De hoogste marapoe is de Schepper, de bovengenoemde Ina KaladaAma Kalada. Deze zendt "Marapoe die beveelt», om zijn wil uit te voeren. Deze heeft de orde in den chaos gebracht; alles is aan hem onderdanig. Hij heeft weer onder zich «de werkmeester onder de goden», of "de Marapoe die de insnijdingen in de handen en voeten makt». Deze voert uit, wat de tweede marapoe uitdenkt. Hij vertegenwoordigt dus als het ware het levenwekkende beginsel. Daarnaast nog een marapoe, «de zoon van vader en moeder . Hij is de algeheele plaatsvervanger van den anderen marapoe met betrekking tot de zaken van de menschenwereld. Hij wordt ook genoemd "de Marapoe die komt en gaat», omdat hij van alles wat hij ziet en hoort in de menschenwereld rapport uitbrengt. Ook onderzoekt hij de geschillen. Hij heet ook «de Marapoe, de meegaat, die volgt, zittend op den schouder en op het hoofd». Een soort van alomtegenwoordige dus.

Ondergeschikt aan die vier zijn de marapoe van de kampong en die van de tuinen en sawahs. De eerste laat de menschen 's morgens en 's avonds uit en in de poort, en de tweede doet de ronde om de akkers.

De levende marapoe worden benaderd door tusschenkomst van de doode marapoe (de zielen der overledenen). De marapoe verschijnen in den droom. "De Marapoe die komt en gaat" verschijnt in de gedaante van een slang. Men zet hem eten voor, en men vraagt hem door middel van wichelen wat hij komt doen (de godsdienstige denkbeelden van de inwoners van Laura zijn beschreven door den missionairen predikant L. Krijger te Karoeni, in de Groninger Kerkbode van 27 Juli en 3 Aug. '18).

Communicatie tusschen Bewaker en Marapoe. De gemeenschap, die de bewaker van den marapoe met dezen onderhoudt, wordt uitgeoefend door middel van wichelen. Daarvoor heeft men verschillende methoden: In de eerste plaats het onderzoek van de lever van het offerdier, dat geslacht wordt: hoen, varken en buffel: is de lever gaaf en goed van kleur, dan is het antwoord gunstig; zijn er gaten of scheuren in of is zij niet goed van kleur, dan beschikt de marapoe ongunstig.

Men kent hier ook het meten van een speer, naar eene methode, die ook op Timor veel wordt toegepast: Een speer wordt met de punt tegen den heiligen paal van het huis gezet, en, 
dan door den ondervrager der geesten gevademd, zoodanig dat de top van den rechtermiddelvinger even tegen paal of rand tikt. Dan omklemt de linkerhand de speerschacht, opdat het lichaam zich niet zal kunnen verplaatsen. Vervolgens laat men de rechterhand los, en tracht met den duim paal of wand te raken. Gelukt dit, dan is het antwoord gunstig; bereikt de duim paal of wand niet, dan is het antwoord ongunstig.

Ook wordt het bloed van de geslachte kip in een bakje of een kokosdop opgevangen; wanneer de oppervlakte van dit vocht glad is, wordt dit aangemerkt als een bewijs dat men gerust kan gaan doen, wat men aan de geesten heeft voorgelegd. Vertoonen zich rimpels, blazen of scheuren op het bloed, dan zal men niet zooveel geluk hebben bij wat men voornemens is te doen. Uit allerlei omstandigneden weet men nog bijzonderheden af te leiden, die op de onderneming betrekking hebben.

Maar het meest wordt het orakelsnoer, de maowal of mowal daarvoor gebruikt. Zij die gewend zijn de geesten te ondervragen, hebben dit snoer altijd bij zich. In een opstel in de Macedoniër (XIV, s't Viervoudig orakelsnoer") heeft Wielenga een uitvoerige beschrijving van dit voorwerp gegeven, en van de wijze waarop er mee gewerkt wordt. De moawal bestaat uit vier touwtjes of koordjes. Twee daarvan heeten vrouwelijk en zijn aan de uiteinden met twee kraaltjes voorzien; de beide andere zijn mannelijk, en bezitten elk slechts één kraal. Terwijl de wichelaar de touwtjes gladstrijkt, spreekt hij ze toe en vraagt aan de moawal of mowal om inlichting over hetgeen hij wenscht te weten of doen en of het hem gelukken zal of niet. Dan strekt hij de touwtjes en spant ze om de vingers. Wanneer hij ze daarvan af laat glijden, kan het gebeuren, dat elk touwtje apart is gebleven, of dat ze hopeloos in de war zijn geraakt. In deze beide gevallen staat de zaak niet gunstig, en een offer moet worden gebracht om beter uitsluitsel te krijgen. $\mathrm{Zijn}$ beide paren touwtjes in elkaar gedraaid, dan mag men op succes hopen, ofschoon de zaak niet gemakkelijk zal gaan. In het gunstigste geval is een mannelijk koord met een vrouwelijk touw samengebonden, zoodat de vier twee strengen vormen. Dit heet dan hepiloeng.

In Bolobokat wichelt men met twee reepjes lontarblad; deze worden eerst op de sirihtasch neergelegd, en de bewaker van het marapoe-huis vraagt den geest om uitsluitsel. Dan worden 
beide reepen over elkaar omgevouwen en de beide einden van iedere reep met elke hand vastgehouden; beide reepen zitten dus in elkaar gehaakt. Eerst wordt nog bepaald of het linkerdan wel het rechterblad moet breken om gunstig of ongunstig te voorspellen. Dan rukt men ze van elkaar en ziet welke van de twee door midden is gescheurd. Is een van de twee bladeren wel geschonden, maar niet doorgescheurd, dan wordt de proef herhaald.

In Napoe (en zeker ook wel in andere landschappen) is men gewend de linkerhand en arm, te beginnen bij den top van den middelvinger met het span van de rechterhand te meten. Drie span naar boven en dan weer drie span naar beneden. Bereikt bij dit terugmeten de top van den middelvinger der rechterhand dien van de linkerhand niet meer, dan is het antwoord van de marapoe ongunstig. Komen de beide vingertoppen weer. op elkaar te liggen, of komt de middelvingertop der rechterhand over dien der linker heen, dan is dit een gunstig teeken.

De Soembanees kent nog vele andere divinatie-methoden, die minder moeten dienen om den wensch van de marapoe te leeren kennen, dan wel om iemands schuld te bewijzen. Dit geschiedt naar de voorstelling der menschen natuurlijk ook op aanwijzing van de marapoe. Algemeen is het leggen van een gloeiend gemaakte bijl op de vlakke hand van den beklaagde nadat ze eerst met eenige boombladeren is bedekt. Ditzelfde doet men soms ook met gloeiende houtskool, maar daarbij wordt de hand niet vooraf met bladeren bedekt.

Algemeen ook is het halen van een ei of een kuiken, uit het water waarin het wordt gekookt. In Laura moet een ei uit kokende karbouwenmest worden genomen. Wanneer bij deze proeven de hand verbrandt, wordt dit als een bewijs van schuld aangemerkt.

Om zijn onschuld te bewijzen laat men in Laura wel iemand met de vlakke hand op een lanspunt slaan. Blijft hij daarbij ongedeerd, dan is hij onschuldig.

Een belangrijke proef is die van het kauwen van gestampte, ongekookte rijstkorrels. Daarbij krijgt ieder van de verdachten een aantal rijstkorrels in den mond, die gekauwd moeten worden. Daarna gaan allen één voor één naar een Soembaneesch schild van buffelhuid, dat ergens tegen den wand is geplaatst. Voor 
deze gelegenheid is het schild van alle versiering ontdaan, en dwars over de huid is met kalk een horizontale streep getrokken, juist in het midden. Ieder moet nu de gekauwde rijst boven het overeindstaande schild uit den mond laten druipen, zoodat deze $o p$ de bovenzijde van het schild neerkomt; de brij loopt dan langs de buffelhuid naar beneden. Is het papje spoedig droog geworden, zoodat het de streep niet of maar even bereikt, dan is de rijstkauwer schuldig, want van een onschuldige zal de uitgespuwde brij vlot over het schild glijden tot beneden toe.

Ten slotte is er nog een proef met Spaansche peper, die in een lapje gedaan en in water wordt uitgeknepen. Nadat tot de geesten is gebeden, moet de vrouw, van wie men weten wil of zij zich aan overspel of bloedschande heeft schuldig gemaakt, dit water drinken. Gaat zij daarna heftig transpireeren en valt zij flauw, dan is daarmee haar schuld bewezen.

Steenen. Het begrip marapoe is niet beperkt tot de zielen van afgestorvenen. Alles wat in verbinding wordt gedacht te staan met onzichtbare machten is $\mathrm{m}$ a rapoe. Een meteoorsteen, watoe kabala, is marapoe; men doet hem in een mandje, en bewaart hem goed. $\mathrm{Nu}$ en dan worden offers aan hem gebracht. Hij dient als medium tot het aanroepen van den Marapoe Kabala: I Randi jalang, i Hodi mali. Hij kan op verzoek van den eigenaar den vijand dooden of ongelukkig maken.

Werktuigen en wapens door de voorouders gebruikt, zijn zelf marapoe; er gaat kracht van uit, die den mensch kan schaden, maar hen ook voorspoedig en sterk kan maken.

Mara poe worden in West Soemba ook de steenen genoemd, die in het Oosten en Midden katoda heeten. Naar hetgeen ik hieromtrent vernomen heb, meenen de Soembaneezen van het Westen, dat van die steenen zelf kracht uitgaat, terwijl in Midden Soemba meer de gedachte daaraan verbonden is, dat die steenen het daar gebrachte offer, of het gedane verzoek, aan de onzichtbare $m$ a r a poe overbrengen. In Midden-Soemba zijn deze steenen dus op weg om eenvoudige offertafels te worden, zooals ze op Timor al veelal zijn. Ter onderscheiding van de boven besproken Marapoe zal ik de steenen met het in Midden-Soemba gebruikelijke woord $\mathrm{k}$ atoda blijven noemen.

De voornaamste $\mathrm{k}$ ato $\mathrm{da}$ is de dorpssteen. In ieder stamdorp namelijk in West Soemba, vindt men een met steenen belegde open ruimte, die rond is, en omringd door een steenen muurtje. 
Dit pleintje heet natara of talora marapoe. Om die ruimte heen staan de huizen der voorname lieden van het dorp; gewoonlijk is daar ook dichtbij het marapoe-huisje. In die ruimte mogen ook alleen de lijken van voorname lieden worden begraven; de minderen liggen er allen buiten. Toen de gewoonten nog streng in acht genomen werden, mochten vrouwen en kinderen alleen bij feestelijke gelegenheden op deze plaats komen, en dan nog alleen vrouwen die in het dorp woonden; vreemdelingen mochten die plek niet betreden, maar liepen er omheen. Maar tegenwoordig stoort men er zich weinig meer aan. Komen soldaten, dan loopen zij er over, en dit voorbeeld is door de Soembaneezen zelven gevolgd.

De gebruiken ten opzichte van de $\mathrm{n}$ atara schijnen in de verschillende landschappen niet dezelfde te zijn. Oemboe Dong van Anakala bijvoorbeeld vertelde mij dat op dit pleintje nimmer beesten geslacht mochten worden; men mocht er zelfs niet eten. Wanneer de dieren geslacht zijn, wordt het vleesch in de huizen om de natara heen gebracht; de levers worden in het marapoe-huisje gebracht, waar ze later door de bewakers der geesten, de ratoe, opgegeten worden. De radja van Lauli daarentegen zeide mij, dat alle buffels op de nata ra worden gedood, en dat men daar ook gezamenlijk eet. Maar bij die maaltijden mag alleen witte rijst worden gebruikt. Boven op die rijst worden gemberwortel en lenga gelegd. Dit lenga heb ik niet thuis kunnen brengen; uit de beschrijving meen ik op te kunnen maken, dat het Coix lacr yma is. ${ }^{1}$ Andere voedingsmiddelen als mais, oebi en dergelijke mogen er niet gebracht worden.

$\mathrm{Op}$ dit plein staat de dorps-katoda: een langwerpige overeindstaande steen, en aan den voet er van een platte steen. Dit is de katoda paraing van Midden-Soemba, de marapoe wano van West-Soemba. In het dorp Taroeng in Lauli, gelijk algemeen in West-Soemba, draagt deze dorpssteen den naam van: Watoe papadendan woedi papamoela, "de opgerichte steen en de geplante woedi (ficus)». Deze steen waakt over het dorp; alles wat de inwoners kwaad zou kunnen doen, weert hij af; voorspoed en geluk houdt hij vast. Wanneer in den ouden tijd de vijand in aantocht was, werd aan dien steen een offer gebracht, en dan gaf men hem kennis: «Morgen komt de vijand,

1 Waarschijnlijk sesam, vgl. Jav. Mal. lĕnga, Tag. linga, Bis. Barè'e longa, Mak. langa. (Adriani). 
help ons dus». Wanneer men zulk eenfsteen in den nieuwen kampong oprichtte, zocht men er een van een zachte kalksoort, watoe poeda, die gemakkelijk bewerkt kan worden. Een hoen werd geslacht en het bloed er van liet men op den steen druipen.

Verder is nog een steen opgericht bij den ingang van het dorp, de katoda langoe paraing (Midden-Soemba), marapoe bina (West-Soemba). ${ }^{1}$ Deze steen moet allen en alles tegenhouden, waţ met een kwade bedoeling binnen wil komen.

Voorts ligt voor iedere woning een steen, de katoda kawindoe, *de steen van het overhangende dak». De geesten die het huis binnen willen gaan, vragen daartoe verlof aan dezen steen, en als de marapoe-geesten uit de woning naar buiten willen gaan, geven ze daarvan kennis aan den steen.

Iedere rijstakker heeft een steen, in M. S. katoda meha, [die alleen staat] in W.S. mata paba [oog van het rijstveld] (of pamba). Wanneer de rijst geplant wordt, en wanneer zij zal worden geoogst, zet men een bordje met rijst en lever op dien steen. In verschillende landschappen in W. S. verzekerde men mij, dat die steenen des nachts zevenmaal om het veld heen loopen om den akker te bewaken. Mislukt het gewas, dan wordt dit niet aan den steen geweten, deze blijft in even groote eere als te voren.

In Taboendoeng, het eenige landschap in O.S. waar veel aan landbouw wordt gedaan, is deze katoda meha, naar mededeeling van den radja van dat land (Oemboe Dai), een steen, waarin een gat is uitgehold. In dat gat legt men eenige goudschilfers (kawadakoe) en daarop weer plaatst men een puntigen steen. ${ }^{2}$

In Wanoekaka is bij de voornaamste bronnen een steen overeindgezet, met vele platte steenen er om heen. Dit is de marapoe katoera, een naam die mij verklaard werd als de "ontginner", de "oorsprong van het landbouwbedrijf». Bij dezen steen worden na afloop van den oogst kippen geofferd. - Ook in Analaka heeft ieder sawahcomplex een katoda, die aan de oostzijde der velden op een sawahdijkje is opgericht, en die daarom katoda kamotoe (kamotoe= sawahdijkje) heet. Dan is er nog een katoda, die wat verweg staat van de sawahs,

1 Langoe paraing, die bericht geeft aan het dorp (nl. wie er binnen wil komen), bin $a=$ deur.

W.

2 Dit is in geheel Oostelijk Soemba de gebruikelijke vorm. Dl. 78 . 
hier naar het Westen. Dit is de katoda kabondoekoe ${ }^{1}$; het is de katoda voor den heelen stam. Hier komt men te zamen met gongslag, hier wordt geslacht en gekookt, en van hier brengt men de offergave naar den anderen katoda.

Ditzelfde vindt men ook in andere landschappen. Gewoonlijk staat de katoda bij het punt, waar het water op de sawah komt; naast den opstaanden steen is gewoonlijk ook nog een liggende geplaatst. In Laura heeft men op de droge velden twee opstaande steenen, en een liggenden. Een van de eerste heet pangamba, "slaaf».

Verder plaatst men nog steenen bij stukken land, waar een geest gedacht wordt te wonen; op zulk een steen, katoda padira tana (grens van het land) geheeten, legt men dan offers voor dien geest. Men bezit ook gemeenschappelijke offersteenen, waar de leden van den stam te zamen komen en offeren om regen af te smeeken, een voordeeligen oogst te vragen, en dergelijke dingen meer. Dit zijn de katoda boenggoer (gemeenschappelijk). Eindelijk heeft men nog steenen op de weideplaatsen van paarden en buffels (katoda ndjara en katoda karamboa), die zorg dragen voor het heil van deze dieren.

Versteeningen. In aansluiting aan dezen steendienst wil ik hier eerst mededeelen, wat ik te weten ben gekomen omtrent menschen, dieren en voorwerpen, die in steen heeten veranderd te zijn. In Taboendoeng, vertelde Oemboe Dai, zijn tijdens den zondvloed vele dieren en menschen in steen veranderd, maar ze zijn niet alle meer aan te wijzen, behalve een steen, die een vrouw geweest is. Deze was aan het weven toen de vloed kwam. Ze wilde vluchten, maar op datzelfde oogenblik veranderde ze in steen.

Dicht bij Wone op den weg tusschen Lauli en Wajewa, is een steen, waarvan men zegt, dat hij vroeger een meisje is geweest. Een vrouw was namelijk eens met haar dochter op het veld aan het werk. Het kind vroeg om water, maar de moeder antwoordde: Hoe kan ik je hier water geven, dat alleen in het dorp te krijgen is. Maar het kind bleef om water zeuren en begon te huilen. Toen het de moeder te erg werd, zei ze ongeduldig: Mocht je een steen worden waar water uitkomt. Haar wensch werd dadelijk vervuld, en tot nu toe vloeit het water

${ }^{1} \mathrm{Kabondoekoe,} \mathrm{in} \mathrm{het} \mathrm{Kamberaasch} \mathrm{paboendoeng} \mathrm{=} \mathrm{opstapelen,} \mathrm{zich}$ verzamelen. Deze is dus identiek met de katoda boenggoer van Oostelijk Soemba.

W. 
uit den neus en de vagina van het in steen veranderde meisje.

Ditzelfde verhaal werd mij ook in Wajewa gedaan, alleen met dit onderscheid, dat het hier een jongen was die steen werd. Deze steen bevindt zich te Lewe ndeta, «hooge berg», dicht bij den kampong Kikoeboko. - Er is ook een bron bij het stamdorp Tanggeba, Wè'è tenge genaamd. Deze Tenge moet een meisje zijn geweest, dat in steen veranderd werd, maar het verhaal dat daaraan verbonden is, wist men mij niet meer mee te deelen. Daar vertelde men mij ook nog van een meisje dat Tiala wioe wawo heette. Deze hield het met een hond, terwijl de dorpelingen aan het feestvieren waren. De hond copuleerde juist met haar, toen haar vader haar riep om op de natara (dorpsplaats), te gaan dansen. Het meisje sneed toen den penis van den hond af om sneller aan het bevel van haar vader te voldoen. Terwijl zij nu aan het dansen was, viel de hondepenis naar beneden, zoodat ieder kon nagaan wat er gebeurd was. Toen het meisje haar vader om water vroeg, omdat zij verhit was van het dansen, antwoordde hij boos: 'Ga naar de bron en kom hier niet meer terug». Het meisje ging, en veranderde daar in steen. Die bron ligt boven Rada kaka, ongeveer drie K.M. van Elo Pada.

Bij het plaatsje Wai Kelo in Wajewa (niet te verwarren met Wai Kelo aan het noorder strand, waar de schepen ankeren) is een steen, die vroeger de menschen waarschuwde, wanneer er vijanden of dieven kwamen. Hij riep de lieden dan. Toen dit weer eens een dief overkwam, hakte hij in den steen, en smeerde hem in met silagoeri-vrucht, en hierna verleende de steen zijn diensten niet meer.

In Laura heet een varken in steen veranderd te zijn. Dit werd door een jager uit Kodi tot in Laura achtervolgd, waar hij het doodde, waarna het in steen veranderde. Die steen bevindt zich bij het dorp Kalimboe komi. Er zijn menschen, die aan dien steen rijst geven, opdat hun akkers niet door varkens verwoest zullen worden.

De legende van Watoe Kaweda is in West-Soemba algemeen bekend. Eens leefde in Boekamberoe in Kodi een vrouw, Kalangga Loroe Wine genaamd. $\mathrm{Zij}$ maakte geregeld reizen van de aarde naar den hemel. Dikwijls ging ze van haar kampong Wèè Taboela (dichtbij het tegenwoordige dorp Wèè Woela) naar het gebergte, en daar verdween zij dan in de rots Wora ngamba. Toen zij eens in haar dorp terugkeerde, zag zij dat een groot varken van 
haar was verdwenen. Op haar vraag wie het varken had genomen, kreeg zij geen antwoord, maar zekere Ina Kaweda fluisterde haar toe, dat de inwoners van het dorp het varken hadden opgegeten. De oude vrouw zeide, dat zij hierover wraak zou nemen, maar Ina Kaweda zou zij beloonen door haar naar den hemel mee te nemen. $Z$ ij gelastte daarom Ina Kaweda gierst te koken als teerkost op den weg, maar in plaats van gierst nam deze boonen. Het koken daarvan hield zeer lang op, en daarom ging de oude vrouw vast vooruit, omdat zij voor zonsopgang weg wilde zijn. Voordat zij heenging vermaande zij Ina Kaweda vooral niet om te kijken, wanneer zij eenig geluid achter zich hoorde. Toen Ina Kaweda eindelijk op weg ging met het mandje voedsel op het hoofd, hoorde zij op de heuvels gekomen een geweldig gedonder achter zich. Ze vergat de vermaning van de oude vrouw en keek om. Ze zag den grond waarop Wèè Taboela stond verzinken. Van schrik veranderde ze in steen. Dit is de Watoe Kaweda bij paal 12 op den weg van Karoeni naar Kodi.

Offerfeesten. Voordat ik tot een ander onderwerp overga, moet ik hier eerst nog iets zeggen van de offerfeesten, welke gehouden worden om de geesten te verzoenen. Mijne inlichtingen daaromtrent stammen uit West-Soemba. Een van die offerfeesten heet roleka. Wanneer er iemand zwaar ziek is, of wanneer een of andere gebeurtenis aanleiding geeft om te onderstellen, dat de geesten ontstemd zijn, wordt door het orakelsnoer, mowal, niet alleen naar de reden van dit misnoegen gevorscht, maar daarmede wordt ook uitgemaakt, langs welken weg men de geesten tevreden kan stellen. Dan gebeurt het wel dat de geesten gelasten om een roleka feest te geven. Dit is een groot offerfeest, waarop eertijds veel buffels en varkens werden geslacht. Van te voren werd aan alle vrienden en verwanten kennis gegeven van het voornemen. Allen die aan het feest kwamen deelnemen, brachten een buffel of een varken mee; later kregen ze dat geschenk weer vergoed, wanneer zij zelven gedwongen waren zulk een feest te vieren.

Eenige dagen voordat het eigenlijke offer gebracht wordt, wordt een stelling in het dorp gemaakt, waaraan vier gongs worden opgehangen. Iederen avond dansen daar zes jongens en zes meisjes, die met kippeveeren en paardehaar versierd zijn. Om de gongs heen dansen ook mannen met schilden voorzien. In een dorp, waar een dorpsplein, $\mathrm{n}$ at a $\mathrm{ra}$, is, worden de gongs 
dicht bij den dorpssteen opgehangen. Het feest begint, doordat iemand tegen den avond op de gong slaat; dan verzamelen zich allen, die aan het feest deelnemen, zoowel de inwoners der feestvierende plaats, als de gasten om den gongslaander heen. Deze strooit gestampte rijst over de verzamelde menigte heen, hij noemt het aantal dieren dat geslacht zal worden, en de namen der marapoe's, voor wie elk der dieren bestemd is. Zoo het eenigszins mogelijk is, wordt aan elk der voornaamste geesten een dier toegewezen, om allen gelijkelijk tevreden te stellen. Den volgenden dag wordt dan alles in orde gebracht en als er weer een nacht verstreken is, worden de dieren geslacht. De ratoe die de leiding van het feest heeft, en die de geesten aanroept, heeft dan een bak met water voor zich staan, waarmee hij de offerdieren besprenkelt, voordat ze worden geslacht. Wanneer dan de offers zijn gebracht, de gebeden opgezonden, en de hoofdmaaltijd is afgeloopen, wordt ook de woning van den feestgever en de verzamelde feestgenooten met dit water besprenkeld. Gedurende de dagen die men bijeen is, wordt veel gedanst, door de vrouwen nenggo, door de mannen kabana geheeten.

Een ander offerfeest van denzelfden aard en met dezelfde bedoeling is het oerata, maar dit is kleinder. Dan worden een gong en een op den grond staande trom, bendoe geheeten, geslagen; er hebben ook geen dansen bij plaats. Bij het slachten der dieren gaat men op dezelfde wijze te werk als bij het roleka,

Een offerfeest van veel kleiner omvang wordt in Laura zaigo, in Lauli jago genoemd. Deze plechtigheid wordt uitgeschreven, wanneer er door een ongeval rijst of mais verbrand is, en men wil met dit feest zorgen, dat de ziel van die gewassen daardoor niet zullen weggaan. Wanneer er gestolen is en men weet niet wie het heeft gedaan, wordt dit feest gegeven ten einde daarbij een vloek over het hoofd van den dief af te bidden. Als iemand door den vijand verslagen is, heeft het zaigo (jago) plaats, om de ziel van den verongelukte terug te roepen. Bij het eerste geval wordt de gong geslagen op den akker of in het tuinhuis, blijkbaar om de ziel van de rijst of de mais te roepen; maar de aanroeping zelf heeft in het dorp plaats. In het laatste geval wordt bij den dorpssteen asch gestrooid, waarop drie haardsteenen worden geplaatst, een nabootsing dus van de stookplaats in huis. Een hekje wordt op die plek gemaakt, waartegen een 
laddertje wordt geplaatst met een onbepaald aantal treden. Den volgenden dag kijkt men dan of men eenig teeken in de asch kan ontdekken, waaruit men zou kunnen opmaken, dat de geesten tevreden zijn met het offer; misschien ontdekt men in de asch den afdruk van een voetstap, die dan afkomstig moet zijn van den verslagene, wiens ziel geroepen is.

Wanneer dit zaigo (jago) gevierd wordt, wordt ook een dag of zeven op gongs geslagen, die aan de bovengenoemde stelling zijn opgehangen, en waarbij 's nachts gedanst wordt; gewoonlijk wordt daarbij slechts een buffel als offerdier geslacht, soms ook wel twee varkens. Het feest vangt als bij het rolek a aan met het slaan op de gong, waarbij degeen die dit doet, in versmaat de reden opgeeft, waarom dit z a ig o wordt gegeven. De Heer L. Krijger heeft in de Groninger Kerkbode van 20 December '19 eenige van deze verzen meegedeeld. Het gezang van den leider der plechtigheid, wanneer wat rijst is verbrand, wordt aldus weergegeven:

Rijst van Koni, rijst van Dima, Kom toch weder, keer terug nu bij de dorpspaal, wees niet bang meer, neem uw plaats weer in ons midden.

Al de geesten van de kampong, die gevlucht zijn, keert toch weder, kom o dorpsgeest, kom o poortgeest, Rijst van Koni, rijst van Dima! Zoon van moeder, zoon van vader, die gevlucht zijn, wees niet bang meer, Kom toch weder, keer terug hier, bij ons allen in de kampong.

Geldt het gezang een dief die met een vloek bedreigd wordt, dan zingt de leider:

Gij o geesten, roept den dief nu, laat hem komen, brengt hem hierheen, dat hij nadre tot de plaats, dicht bij de trommel en de gong. Laat hem daar zijn schuld erkennen, dat hij zegge: sla mij vrij nu, want ik ben het, ik beken het, $\mathrm{ik}$, die heb gestolen 't goed. 
Is hij zelf soms op het feest hier, hoort hij zelf ook onze woorden, laat hij 't dan wel overwegen in zijn hart, en 't feit bekennen.

Heeft de dief zich niet aangemeld, dan wordt de vervloeking uitgesproken :

Gij o geesten, volgt den dief nu, slecht van voeten, slecht van handen, dat hij sterve en niet leve, al zijn magen, grooten, kleinen. Wat zijn hand ook moge planten, dat geen zegen 't doe gedijen.

Als men de ziel van een verslagene terugroept:

Onze broeder, die gegaan zijt langs den grenspaal van de sawah, opgestegen naar den hemel, daal nu weder tot ons neer. Keer terug nu tot den Schepper van uw handen, van uw voeten, en gij Schepper, roep ook zelf hem, die nu dood is, tot ons weder, Heeft hij eertijds overtreden, stierf hij daarom bij het strijden, trof de lans hem van den vijand, dat hij nu dan wederkeere. $Z$ ie de ladder staat gereed hier, om $\mathrm{u}$ tot ons te geleiden. Klim dan nu weer naar beneden, tot ons weder van den hemel.

Soms wenscht men den marapoe uit de woning naar de tuinhut over te brengen. Dit noemt men lèke marapoe, of lèke (vinden) pare (rijst). Dit doet men door een deel van de geoogste rijst uit de woning naar het tuinhuis over te brengen, te zamen met een of meer kinnebakken van varkens die bij verschillende gelegenheden geslacht zijn, en die bij de offerplaats in huis zijn opgehangen. Dit gaat met eenige plechtigheid gepaard.

Maar nu gebeurt het ook wel eens, dat het orakelsnoer uitmaakt, dat iemand ziek geworden is, omdat hij zijn rijstveld 
geruimen tijd in den steek gelaten heeft, waarom de indertijd daarheen gebrachte geest van den akker boos geworden is, en nu den eigenaar ziek gemaakt heeft. Dan wordt eerst op de gewone wijze in huis gebeden, en vervolgens gaat men in optocht naar den akker. Een oud man gaat voorop met een veelkleurigen doek op het hoofd en een lans over den schouder. Onderweg zingt hij en zijn gezang wordt telkens met gejuich beantwoord. In de tuinhut aangekomen spreekt hij daar weer eerst gebeden uit, waarin den marapoe wordt verzocht om mee te gaan naar het dorp, opdat hij niet alleen op het veld achterblijve. Dan wordt een kip geslacht, en uit de lever wordt opgemaakt of de marapoe genegen is mee te gaan. Wanneer uit de lever blijkt, dat hij daartoe niet genegen is, dan slacht men een varken om hem over te halen. Wanneer de marapoe door de lever van dat dier te kennen geeft, dat hij ook daarmee niet tevreden is, dan wordt hem een groot offerfeest beloofd. De marapoe heet zich vereenzelvigd te hebben met een pinangnoot; deze wordt na afloop van de plechtigheid te zamen met de vroeger daarheen gebrachte kinnenbakken naar het dorp gebracht, en daar op haar oude plaats opgehangen. Op deze wijze is de marapoe weer in huis terug gebracht.

Familieverwantschap. Toen ik boven over marapoe sprak, heb ik reeds medegedeeld, dat een dorp bestaat uit lieden, die hun afstamming afleiden van denzelfden mannelijken voorouder. De hoofdman van zulk een gemeenschap heet kabiso $\mathbf{e}^{\mathbf{1}}$, en allen die zich om hem heen groepeeren, heeten tot dezelfde kabisoe te behooren. De kabisoe is het die voor zijn geslacht de godsdienstige handelingen en de jaarlijksche offeranden regelt. In zijn huis worden de oude erfstukken bewaard, die als medium dienst doen in het verkeer met den voorvader, van wien het geslacht afstamt. De namen van de verschillende familieverhoudingen heeft Wielenga reeds gegeven in zijn Vergelijkende Woordenlijst onder de nummers $69-88$, zoodat ik die hier niet behoef te herhalen.

Op Soemba heerscht vaderrecht, dat is: dat de kinderen behooren tot het geslacht van den vader. Afstammelingen van

\footnotetext{
$1 \mathrm{Kabisoe}$ met het honorifieke prefix ka-gevormd van bisoe, Boeg. id., Jav. wikoe, Tag. Bikol biko, Minahassische talen: wikoe, witjoe, Bare'e bikoe, Mal. bisoe (stom), in 't algemeen „onthouder, die zich bepaalde genoegens (coitus, palmwijn) ontzegt en daardoor magisch sterk wordt". (Adriani).
} 
denzelfden voorvader, $\mathrm{kab}$ is o e, mogen niet met elkaar huwen, omdat dezen elkaar bestaan als broeders en zusters. Hieruit zou volgen dat de kinderen van twee zusters, wanneer ieder harer gehuwd is met een man uit verschillende kabisoe, met elkaar zouden mogen trouwen. In enkele landschappen in het Westen is dit ook het geval, zooals in Laura, Wajewa, Wanoekaka en Lauli. In Bolobokat, Napoe en Anakala mag het ook, maar onder zekere restrictie: de zoon van een jongere zuster mag met de dochter van een oudere zuster huwen, niet andersom. Toch kon dit laatste gebeuren, maar dan werden de kinderen eerst aan andere familieleden gegeven, die dan als hun vaders optraden en voor den bruidsschat zorgden, welke dan toch ten slotte aan den eigenlijken vader van het meisje werd gegeven. In het landschap Lamboja in West-Soemba zei men mij bepaald, dat kinderen van twee zusters niet met elkaar mogen huwen, iets dat ook in Midden-Soemba regel is, zooals ik zelf in Kambera, Lewa en Lakoka heb kunnen nagaan.

Een huwelijk dat zeer gewenscht, ja voorgeschreven is, is dat tusschen den zoon van een zuster en de dochter van een broer. Dit heet pa'anawini-pa'anamining. Wanneer zulk een verbintenis door een der partijen wordt geweigerd, geldt dit voor een groote beleediging. Alleen in Wajewa vertelde men mij, dat ook een dochter van de zuster met den zoon van haar broer mag huwen. Ik durf echter niet zeggen of dit daar algemeene regel is.

Toch wordt in bijzondere gevallen wel toegestaan, dat broers zoon met zusters dochter huwt, bijvoorbeeld wanneer van een broer en zuster de eerste alleen zoons en de tweede alleen dochters heeft. Maar zulk een huwelijk moet dan "ontzondigd, worden (hawari). Het kan ook voorkomen, dat de dochter van den broer al groot is, terwijl het zoontje van de zuster nog klein is. Dan kan die dochter aan den vader van dat zoontje, dus aan den man van de zuster tot vrouw worden gegeven. Is de jongen groot geworden, dan moet de vader van de dochter een vrouw voor zijn neef zoeken, en de vader van den jongen moet aan den bruidsschat meebetalen. Is het geval andersom, en de zoon van de zuster reeds volwassen of oud, terwijl het dochtertje van den broer nog klein is, dan is die zoon toch verplicht zijn nichtje te nemen, als tanggoe toekoe, "sirihstampstertje, en hij moet haar zeer duur betalen. Deze gewoonten 
zijn van Kambera opgeteekend, maar ze gelden ook voor WestSoemba.

Uit dit vaderrechtelijk stelsel vloeit van zelf voort, dat een man met de weduwe van zijn broer mag huwen, en wel zonder bruidsschat te betalen. Twee broers kunnen ook gehuwd zijn met twee zusters, mits deze uit een andere $\mathrm{kabisoe} z \mathrm{ijn}$. Dat een man met twee zusters tegelijk gehuwd zou zijn, schijnt weinig voor te komen. De adat verbiedt het niet. Eén geval daarvan heb ik in mijn reisverslag verteld, waar het dorpshoofd van Pamala met twee dochters van den radja van Bolobokat gehuwd was. Maar gewoonlijk staat de vrouw niet toe, dat haar man haar zuster als tweede vrouw er bij neemt. Na haar dood is het geoorloofd.

Wat algemeen verboden is, is dat de man huwt met de zusters van zijns zusters man. 'Sommigen verklaren dit verbod uit de omstandigheid, dat de eene partij dan niet meer bruidsschat zou mogen bedingen, dan zij voor de dochter van de andere partij heeft betaald: terwijl het bij de Soembaneezen een soort van sport is om bij een huwelijksovereenkomst zooveel mogelijk van elkaar te halen. Maar de ware reden moet gelegen zijn in de familieverhouding, die door het huwelijk van de eene partij ontstaat. Want de zuster van mijns zusters man is mijn lajia, en ik ben voor haar $\mathrm{jera}$, en deze verhouding wordt beschouwd te zijn als die van broer en zuster tusschen welke twee een huwelijk niet mogelijk is. Daarom heet zoo'n verhouding: pajerapalajia (in Wanokaka zegt men lija voor lajia; in Lamboja lejawa, in Lauli lasawa). In dezelfde verhouding tot elkaar staan ook de man en de echtgenoote van zijns vrouws broer. Komt de laatste te sterven, dan mag zijn zwager nimmer met de weduwe huwen. Men vertelde mij, dat de vorsten van Kambera toch wel zulke huwelijken sluiten, maar zij weten ze alleen door hunne macht door te zetten.

Een huwelijk van een man met de zuster van zijn schoonvader of schoonmoeder is in sommige streken uitgesloten: zoo ook dat van een vrouw met den broer van haars mans vader of moeder. In Taboendoeng mag dit echter wel. Zelfs mag daar een man na den dood zijner vrouw met haar moeder (als deze weduwe is) huwen, in geval hij bij de dochter geen kind heeft. Een aangetrouwde oom mag in alle gevallen met het nichtje zijner vrouw huwen, ook al heeft hij bij zijn vrouw, dus de 
tante van zijn tweede vrouw kinderen verwekt. Zoo ook mag een aangetrouwde tante met den neef van haar man trouwen.

Huwelijksgemeenschap tusschen lieden van denzelfden kabisoe wordt beschouwd als bloedschande. Men heeft het vaste geloof dat bloedschenders niet lang kunnen leven. En daarom moeten ze, als hun daad bekend wordt, tegen zichzelve beschermd worden. Nergens op Soemba heb ik kunnen ontdekken, dat men aan het plegen van bloedschande de gedachte verbindt, dat daaruit een ramp voor het heele volk zou kurnen voortkomen: droogte of overvloedige regen, of iets dergelijks. De schuldigen werden dan ook nooit gedood. Een paar maal kreeg ik op een desbetreffende vraag ten antwoord: Waarom zou men zijn eigen bloedverwanten dooden? Alleen Taboendoeng makt hierop een uitzondering. De radja, Oemboe Dai, zei mij, dat bloedschenders vroeger gedood werden, hetzij met het zwaard, hetzij door wurgen.

Het is bijna altijd een hond die gedood wordt om bloedschande te verzoenen; alleen de wijze waarop dit geschiedt, verschilt in sommige streken. Zoo houdt in Kambera de vrouw een kleinen hond in een doek gewikkeld vast. $\mathrm{Zij}$ en de schuldige man staan voor den leider, die de marapoe aanroept. Daarna geeft de leider den hond een slag, die hem doodt, en tegelijkertijd laat de vrouw den doek, waarin het dier gewikkeld is, vallen. Het beestje wordt daarna in tweeën gehakt, en de eene helft naar het Oosten, de andere naar het Westen opgehangen. De doek is voor den bidder. Zonderling genoeg heet deze plechtigheid: lo pangangoe ahoe, «een hond gaat eten». terwijl juist bij deze gelegenheid niet gegeten wordt, ofschoon de Soembanees een groote liefhebber van hondevleesch is.

De radja van Bolobokat vertelde mij, dat wanneer de bidder den hond voor zich wil sparen, hij het dier een ferme tik op den kop geeft, zoodat het schreeuwt, waarna hij zegt: hij is dood. Hij neemt daarna het dier, dat ongedeerd is, naar huis mee.

In Anakala geeft die man aan de vrouw een ring, en de vrouw geeft den man hetzelfde. Deze ringen worden in een kom met water gedaan, waarin ook eenige goudschilfers, kawâdâkoe, zijn geworpen. Aan beide zijden van de kom ligt een sarong, één af komstig van den man, één van de vrouw. Wanneer een hond is doodgeslagen, en de schuldigen met het water uit de kom zijn besprenkeld, loopen man en vrouw van elkaar weg, de sarong die naast de kom gelegen heeft met zich meenemende. 
Thuis gekomen verwisselen ze de besprenkelde sarong met het kleedingstuk, dat naast de kom gelegen heeft. (Als kwast bij dit besprenkelen worden bladeren gebruikt van de kandangoe, en heeft men deze niet bij de hand, dan gebruikt men die van een ficussoort, de wangga).

In Midden-Soemba treedt men in gevallen van bloedschande toch strenger op dan in West-Soemba. De schuldige man wordt daar naar een broer van zijn vader gebracht, die hem onder handen moet nemen. Het meisje wordt zoo spoedig mogelijk uitgehuwelijkt, maar haar vader moet daarbij een boete betalen aan den man, die met dat meisje huwt, een boete die uit manden met Soembasche weefsels gevuld, bestaat. Van zulk een boete heb ik in West-Soemba niet gehoord. Maar in elk geval worden de schuldigen ook in Midden-Soemba ontzondigd, sekoe of hawari (Mal. tawar) met wai maringoe, "koud water», en het slachten van een dier, een buffel of een varken. De plechtigheden die daarmee gepaard gaan, verschillen hier en daar. Gewoonlijk geven de schuldigen ieder een doek, die het eigendom wordt van dengene die de plechtigheid voltrekt. In Mangili (Oost-Soemba), worden bij deze gelegenheid twee honden geslacht, waarvan de ingewanden aan elkaar gebonden worden, te zamen met een stukje van de sarong der vrouw en een stukje doek van den man. Dit alles wordt in zee geworpen opdat de zee het afdrijve.

In Lamboja (W.S.) wordt door den schuldigen man een hond dood geslagen die door den leider der plechtigheid daarna naar het Westen wordt geworpen. De bloedschender geeft ook een kapmes en een speer: het eerste om daarmee in de aarde te hakken, opdat deze van de ontzondiging "hoore»; de tweede om daarmee naar den hemel te steken, opdat deze ook getuige zij van de plechtigheid. Beide voorwerpen worden het eigendom van den leider. Dit gebruik zou er op kunnen wijzen, dat men van bloedschande wel kwade gevolgen verwacht voor den landbouw, zoodat de aarde geen vrucht en de hemel geen regen meer geeft. Op dezelfde wijze gaat het in Lauli toe, alleen vermeldde men er daar nog bij, dat de hond die bij deze gelegenheid gedood wordt, geen afgesneden staart mag hebben.

In Wajewa wordt de plechtigheid volbracht door iemand, die de kunst verstaat om tot de marapoe te bidden, een zoogenaamde ata oerata, of «darmkijker», die uit de ingewanden 
van het offerdier kan opmaken, wat de wensch van den marapoe is. De vader van de schuldigen mag dit werk doen; de schuldigen zijn er gewoonlijk niet bij tegenwoordig. Eerst wordt een hoen geslacht, waarvan de kop naar het Westen, en het lichaam naar het Oosten wordt geworpen. Daarna wordt een geleding bamboe gespieten, waarvan de beide helften op dezelfde wijze naar Oost en naar West worden gegooid. Daarbij roept de leider zon en maan aan, en deelt aan deze mede, dat zij nu alle kwaad van zich hebben gedaan.

Op den algemeenen regel, dat iemand niet met een kabisoegenoot mag trouwen komen wel uitzonderingen voor: zoo vertelde de radja van Taboendoeng $\mathrm{mij}$, dat het wel voorkomt dat de kleinkinderen van twee broers of twee zusters met elkaar trouwen, wanneer het geslacht anders zou uitsterven, of wanneer dit om een andere reden wenschelijk wordt geacht. De plechtigheid van het ontzondigen, zooals deze pas beschreven is, heeft dan plaats, maar na afloop er van blijven man en vrouw bij elkaar. Dit is in gewone gevallen van bloedschande natuurlijk niet het geval. Komen gescheiden bloedschuldigen weer bij elkaar, dan heeft de ontzondigingsplechtigheid nog eens voor hen plaats. Willen zij dan toch geen afstand van elkaar doen, dan laat men het paar aan zijn lot over. Het bouwt zich dan ergens een hutje, maar de anderen staan niet toe dat ze in het dorp komen.

In Laura noemt een man ieder meisje van zijn $\mathrm{kabisoe:}$ gho'o, zuster; en een meisje noemt iederen man van haar stam na'a, broeder. Een huwelijk tusschen deze twee is niet mogelijk. Maar nu zijn er enkele $\mathrm{k}$ abisoe, die in tweeën gedeeld zijn, en onder zekere voorwaarden kan een man uit het eene deel met een meisje uit het andere deel trouwen. Dit komt ook in andere landschappen voor, zooals wij zullen zien. Naar de oorzaak, die tot zulk een verdeeling heeft geleid, heb ik vergeefs gezocht. Ik vermoed, dat aanleiding tot zulk een verdeeling heeft gegeven de daad van een radja, die de adat geweld aandoende toch een meisje uit eigen kabisoe heeft genomen, waarna men er een mouw aan heeft gepast, door de kabisoe te verdee!en, dus een soort nieuwe kabisoe te maken. Komt zulk een geval voor, dan moet het meisje eerst aan een familielid van een anderen kabisoe worden overgegeven; ze moet daarin worden opgenomen. Het meisje zelf verhuist daarheen daags voor den trouwdag. 
Over hetgeen er verder gebeurt laat ik hier volgen wat L. Krijger in de Groninger Kerkbode van 9 Maart 1918 schriift: «Het moet nu echter den schijn hebben ${ }^{1}$, alsof zij altijd tot die familie behoord heeft. Daarom wordt zij verondersteld zoo juist in die familie geboren te zijn. Men bootst dan al die handelingen na, die gewoonlijk bij de geboorte van een kind plaats vinden. De bruid wordt geheel als een pas geboren wicht behandeld, en zelf gedraagt zij zich ook zoo. Den ganschen nacht wordt zij op de schnot van een oude vrouw gewiegd.... De bruidschat wordt dan ook door deze plaatsvervangende familie in ontvangst genomen, welke ook door haar met de gebruikelijke geschenken moet beantwoord worden.»

Van Lauli beneden deelde de Gezaghebber J. M. Canisius mij een dergelijk geval mede. Een deel van een oorspronkelijk uit Wai Bangga afkomstigen stam vestigde zich in Lauli. Op het oogenblik wonen in de hoofdkampoeng Taroeng van genoemd landschap drie kabisoe: Ana Wara, die den voorvader Tagoe Weoe Tade Loegoro als marapoe vereeren: Wae Lowo, met zijn marapoe Koga Kadi, en Wae Tabora met zijn marapoe Toko Jangoe. $\mathrm{Nu}$ is laatst genoemd geslacht weer in tweeën gedeeld, waarvan het eene deel de goba kado, lett. *vijand buffelhoorn", van het andere wordt genoemd. Een man uit het eene deel mag met een meisje uit het andere trouwen, mits de vrouw niet uit haar eigen woning trouwt. Den avond voor den dag, waarop zij door den bruidegom zal worden afgehaald, gaat zij bij iemand van een andere kabisoe slapen. "De bewoner van het huis, zegt de Heer Canisius, speelt pro forma voor den vader, en geeft een kain aan den trouwlustigen jongeman, slacht een varken, behandeld dus het meisje als zijn eigen kind».

Als toelichting op de benaming goba kado schrijft de Heer Canisius: "Bij karbouwenslacht worden de horens bewaard, en dienen als sieraad aan de woning van den slachter (eigenaar). By goba kado echter behoudt niet de eigenaar de horens, maar geeft hij ze af aan iemand van de andere partij. Deze hangt ze thuis op».

Kodi. Op den algemeenen regel van vaderrechtelijk stelsel

1 Dit is niet geheel juist; de nieuwe geboorte moet werkelijk plaats hebben en wordt dan ook door het hier beschreven gebruik tot een feit gemaakt, dat al de gevolgen eener werkelijke geboorte heeft. 
op Soemba maakt het landschap Kodi in het uiterste Westen een uitzondering. Want hier volgt het kind het geslacht, de kabisoe, of zooals men het in Kodi zegt: de wela van de moeder. Er zijn meer dan twintig van deze wela. De namen van enkele der voornaamste volgen hier: Wela Loge, w. Giawi, w. Atoere, w. Bila, w. Koeolo, w. Kerobo, w. Likata, w. Ganggara, w. Hiedo, w. Anggata, w. Kepedoe. Volgens mijn zegsman kunnen geen nieuwe wela ontstaan. Eerstgenoemde wela is het meest gezien, en ook het grootste in aantal. De tweede in aanzien is w. Ganggara. Iedereen weet tot welke wela hij behoort, maar overigens wonen leden van verschillende wela door elkaar. Hier is verdeeling van het landschap in Kodi bokoel en Kodi Mangedo een zuiver plaatselijke.

Al volgt het kind het geslacht van de moeder, zoo kan men toch niet zeggen, dat in Kodi moederrecht heerscht, want door het betalen van den bruidsschat, die even hoog is als in Laura, en die van de gegoedheid der ouders afhangt, krijgt de man macht over de vrouw, en over de weezen, die hij achterlaat, hebben zijne verwanten en niet die van de moeder het beschikkingsrecht.

Toch schijnt het in Kodi regel te zijn, dat de man bij zijne vrouw blijft inwonen, en het gaat gewoonlijk met eenige moeielijkheid van de zijde der ouders van de vrouw gepaard, wanneer de man zijn echtgenoote naar zijn eigen woning wil brengen. Meestal geschiedt dit door schaken: Man en vrouw spreken samen af, dat de laatste op een bepaald uur water of hout zal gaan halen. Bij die gelegenheid ontvoert hij haar dan. Later wordt de bruidsschat, nga'oe, afbetaald.

Wanneer twee lieden uit dezelfde wela het met elkaar houden, wordt dit als bloedschande beschouwd. De schuldigen worden niet gedood. Dit zou alleen kunnen gebeuren, wanneer de man weigerde van de vrouw afstand te doen. Ook zou de man wel eens gedood kunnen worden, wanneer het meisje van dezelfde wela, met wie hij het hield, van een aanzienlijke familie ware, en de man zelf van geringe afkomst. Anders wordt zoo'n geval "koud gemaakt», op eenzelfde wijze als boven beschreven is.

Huwelijk. Bij het huwelijk speelt de bruidsschat een zeer groote rol. De Heer Wielenga en de Bestuursambtenaren zeiden, dat het grootste deel der rechtszaken voortkwam uit geschillen over den bruidsschat. Dit vindt vooral zijn oorzaak hierin, dat men reeds geschenken begint af te geven op meisjes van één 
en twee jaar. En de vader van de kleine neemt niet van één persoon zulke geschenken aan, maar van verschillende pretendenten, zoodat dit later, wanneer het tot een huwelijk met een van hen moet komen, aanleiding geeft tot allerlei verwikkelingen. Want al het geschonkene moet dan weer worden teruggegeven aan de teleurgestelde minnaars. Daar aan dit geven van geschenken met de hoop op een toekomstig huwelijk geenerlei afspraak verbonden is, wordt geen boete geeischt, wanneer het huwelijk niet kan doorgaan. Bij het tot stand komen van zulke huwelijken wordt veel dwang uitgeoefend op de jongelieden, maar meermalen stuit het voltrekken er van op hun onwil af.

De bruidsschat, in het Oosten banda (goederen), in het Westen weli na mawine (prijs der vrouw) geheeten is bijzonder hoog; in het Oosten weer hooger dan in het Westen, maar hij is toch overal zoo, dat velen ongetrouwd moeten blijven, omdat zij geen bruidsschat kunnen betalen. Dit geeft aanleiding tot allerlei ongewenschte toestanden. In Laura is de bruidsschat over het geheel lager dan in de andere landschappen, gemiddeld een waarde van $f 75$. - vertegenwoordigend, maar er komen altijd zooveel geschenken bij, dat hij toch een flinke hoogte bereikt. De bruidegom toch moet behalve den bruidsschat, aan alle naaste familieleden der vrouw een geschenk geven, zelfs een nog ongeboren wicht moet zijn deel ontvangen. Zoo gaat een huwelijk in het Qosten ook gemeenlijk met geschenken aan den radja gepaard, daar hij in de verbintenis gekend moet worden. Daardoor gaat aan dien kant de bruidsschat vaak de waarde van $\mathrm{f} 1000$. - te boven. Bij de besprekingen van iederen bruidsschat tracht de familie van de vrouw zooveel mogelijk te bedingen, en in elk geval zal de vader van het meisje minstens evenveel voor zijn dochter willen ontvangen, als hij voor haar moeder heeft gegeven.

Overal vertelde men mij dat de bruidsschat in vroeger dagen veel minder bedroeg dan tegenwoordig. Meestal werd dit in verband gebracht met de meerdere welvaart, die er in de laatste vijftig jaar is gaan heerschen door den paardenhandel, maar ook andere omstandigheden moeten daaraan meegewerkt hebben, want in West-Soemba waar de welvaart niet toegenomen is, wist men eveneens te vertellen van een lageren bruidsschat in vroegere jaren. Zoo werden volgens de verhalen van oude lieden in Kambera slechts twee of drie paarden als bruidsschat betaald, terwijl deze nu van $15-20$ en van $50-100$ gouden oorhangers, 
mamoeli, bedraagt, behalve een groot aantal paarden en buffels. Ook in Lewa was de bruidsschat niet hoog; men gaf wel goud, maar weinig. Wanneer de bruidsschat gebracht werd, placht men hier vroeger te zeggen: "Daar komen het ijzer en de hond aan». $\mathrm{Nu}$ spreekt men van: mabara, marara, "wat wit is (zilver), wat geel is (goud)». De hond droeg den naam van "de stem van den man», de stem van de vrouw». Het ijzer doelde op een speer of een zwaard, dat steeds bij den bruidsschat aanwezig moest zijn. Deze gewoonte wordt nog hier en daar in Lewa gevolgd.

In Laura worden een of meer beesten aan den bruidsschat toegevoegd, die in de plaats van slaven heeten gegeven te zijn, waaruit blijkt dat eertijds ook wel slaven gegeven werden. Verder bestaat daar een gewoonte, die aan de huwelijksgebruiken op Timor doet denken: Een fraaie gouden oorhanger wordt gegeven "voor het rechter oog van de bruid", en een van minder waarde "voor het linker oog".

Van de zijde van de ouders der bruid worden ook zware offers geeischt, want over heel Soemba is het gewoonte, dat de bruidsschat door tegengeschenken gedeeltelijk wordt vergoed. Het is dan weer de beurt van de familie van den man om zooveel mogelijk binnen te krijgen. Hieruit volgt alweer, dat alleen families, die denzelfden welstand genieten hunne kinderen aan elkaar kunnen uithuwelijken.

Deze tegengeschenken heeten in West-Soemba nga'oe, een woord, dat in het dialect van Kambera de beteekenis heeft van "brons». Dit doet onwillekeurig de gedachte opkomen, dat koper en brons, 't welk nu geen rol meer op Soemba speelt, vroeger meer in trek is geweest.

Juist met het oog op den bruidsschat wordt er goed op gelet uit welk geslacht men zijn vrouw kiest, want wanneer men zijn vrouw neemt uit een verwante kabisoe, dan is de bruidsschat minder dan als hij genomen wordt uit een streek, aan welker bewoners men niet verwant is. Zoo zijn de geslachten Ana mboeroe in Pajeti en Lèba Karoekoe in Kambera aan elkaar verwant, en is een huwelijk tusschen een paar van hun leden onderling nog te doen. Maar wanneer bijvoorbeeld een man van Kaboeroe of Loera in hetzelfde landschap een vrouw uit een der genoemde geslachten neemt, dan moet hij alles betalen wat hem gevraagd wordt.

Ik heb ook herhaaldelijk de vraag gedaan of een jongere Dl. 78. 
dochter mag worden uitgehuwelijkt, wanneer haar oudere zuster nog geen man heeft. In Lewa verzekerde men mij, dat dit mocht. Begeert iemand de jongere zuster, als de oudere nog ongetrouwd is, dan moet hij ze beiden maar huwen. In Napoe, ook tot Midden-Soemba behoorende, vertelde de radja mij, mag men wel met een jongere zuster eener ongehuwde trouwen, maar de bruidegom moet er op rekenen, dat de oudere zuster van zijn bruid hem de ooren van het hoofd zal vragen, en alles wat zij eischt is hij verplicht te geven. In West-Soemba mag men altijd de jongere zuster huwen terwijl de oudere nog geen man heeft, maar de man moet aan die oudere zuster wel een geschenk geven, meestal een Soembaneeschen doek en een gouden vorhanger, mamoeli.

De wijze waarop een huwelijk tot stand komt, is dezelfde als die welke nagenoeg overal in den Archipel gevolgd wordt. Vaak hebben de jongelui al in het geheim een afspraak gemaakt, maar toch komt in zulk een geval een zendeling van de familie van den man officieel om de hand van het meisje vragen. Het eenige, dat hij als geschenk bij zich heeft, is wat sirih-pinang en een kain die bij het aanzoek aan de familie van de vrouw wordt overgereikt. Wanneer het verzoek is aangenomen, komen beide partijen op een afgesproken dag bij elkaar. De vader van den bruidegom brengt bij deze gelegenheid vast een buffel of een paard mee. De vader van de bruid slacht een varken om de gasten te eten te geven, dat hij geeft als tegengeschenk voor den door den vader van den bruidegom medegebrachte Soembaneeschen doek. Hiermede zijn de onderhandelingen geopend, en de dag wordt bestẹed om de grootte van den bruidsschat en de tegengeschenken vast te stellen.

$\mathrm{Bij}$ het onderhandelen over den bruidsschat, wat een zeer langdurige zaak is, wordt de huis-Marapoe als getuige aangeroepen. Daartoe worden op het offerrek, Oost-Soemba jarang, twee gouden oorhangers, mamoeli, en een gouden ketting, kanatar, neergelegd, benevens een offerande. Deze voorwerpen blijven daar liggen tot het huwelijk gesloten is, waarna ze weer met het brengen van een offer er afgenomen worden.

Is de trouwdag aangebroken, dan wordt in West-Soemba de bruigom in optocht naar de woning van de bruid gebracht. Zoo eenigszins mogelijk wordt de bruidsschat medegevoerd. Maar in ieder geval gaan er twee buffels mee; de een wordt geslacht 
voor het bruiloftsfeest, de andere heet Pateba na oembana, geslacht voor het zwagerschap. In Laura voert men drie buffels met zich mee. Hiervan wordt een voor het bruiloftsmaal geslacht; de tweede is bestemd voor de marapoe van de bruid, en de derde wordt aan den broer van de bruidsmoeder gegeven. Deze laatste persoon speelt ook nog een rol bij de begrafenisgebruiken. Inplaats van dieren worden voor de twee laatste buffels ook wel geschenken gegeven. Als tegengeschenk geeft de vader van de bruid een met gouddraad doorweven doek aan den bruidegom, terwijl hij ook een paard en een buffel schenkt, zooals het heet om daarop de bruid naar het huis van den bruidegom te vervoeren. (In de plaats van deze dieren werden vroeger ook wel een speer en een hakmes gegeven). Ook moet hij zorgen voor twee varkens, die den naam dragen van wai mate, wai moripa, «dood varken, levend varken», omdat een er van gedood, en het andere in leven gelaten en door de bruid naar haar nieuwe woning meegenomen wordt. Wat de bedoeling hiervan is, wist men niet te vertellen. Het slot van het feest is, dat een hoen wordt geslacht, waarbij de geesten worden aangeroepen; de lever van dit dier wordt onderzocht, omdat die het lot van het jonge paar moet voorspellen. Wanneer het vleesch van het hoen is gekookt, eten bruid en bruidegom er beiden van.

Meermalen wordt de bruid dadelijk na afloop van de huwelijksplechtigheid naar de woning van den man gebracht. Wanneer het jonge paar dan het dorp van den man binnen gaat, staat daar een man met een bakje rijstkorrels, waarmede hij bruid en bruidegom bestrooit. Na afloop daarvan bidt hij tot de marapoe met aanbieding van een offer. Bij aanzienlijken gaf men vroeger aan de bruid een jongetje of meisje als "volgeling » mee; dit was de ata lili kalekoena, "de ondergeschikte, die de sirihtasch (voor zijn meesteres) draagt». In het huis van den bruidegom volgen dan enkele dagen van feestvieren, gedurende welken tijd de jonge vrouw niet uit de woning mag gaan. Dit geschiedt na afloop van de feestelijkheden met eenige plechtigheid, waarna de jonge vrouw zich gaat baden, en als huisvrouw optreedt.

De vrouw brengt eenige goederen mee naar haar nieuwe woning, bestaande uit doeken, kostbaarheden, en vroeger ook eenige slaven en slavinnen. Dit geldt vooral voor Oost-Soemba. 
Deze goederen en slaven bleven haar eigendom. De kosten van het huwelijk der kinderen in lateren tijd worden voor een groot deel uit dit eigendom betaald. De man mag deze goederen zijner vrouw niet vervreemden; alleen in hoogen nood geeft de de vrouw soms hare toestemming daartoe. Alleen de kostbare kralen, waarmee de vrouw zich bij feestelijke gelegenheden tooit, mogen nooit worden weggedaan. Deze erft de oudste dochter.

Het verloop van een gewone bruiloft zooals deze hier voor West-Soemba is beschreven, geldt in hoofdzaak ook voor Middenen Oost-Soemba. Maar het kan ons niet verwonderen, dat in laatst genoemde streken door den invloed der radja's een uitgebreider en luisterrijker ceremonieel in acht genomen wordt. Een eigenaardige gewoonte in het Oosten, die niet in het Westen bestaat, is die van het gebruik van een ana mamoha. Dit is een meisje, dat gedurende het gansche verloop van de huwelijksceremoniën de bruid vertegenwoordigt. $Z$ ij zit voortdurend mooi aangekleed en met een doek over het gelaat op de plaats, waar de bruid moet zitten, terwijl deze zelve overal rond loopt en haar gewonen gang gaat. Deze an a mamoha wordt uit een anderen stam gehaald, of door een bevriend hoofd geschonken. Men noemt dit lo pajăpa ana mamoha, "een ana mamoha gaan vangen».

Wanneer de bruid naar de woning van haar man is gebracht, volgt de ana mamoha, die steeds nog als representant van de bruid optreedt gedurende de feestelijkheden in de nieuwe woning. Aan het einde van de pret heet het dan: papoeroe ana mamoha, "de ana mamoha naar beneden halen». Deze gaat zich dan baden, en na afloop daarvan is zij weer een gewoon slavinnetje, de lijfmeid van de jongetrouwde vrouw.

Deze meisjes genieten eenig aanzien, omdat zij in een bepaalde betrekking tot het aanzienlijke jonge paar staan. Het behoeven ook geen slavinnetjes te zijn. Later huwen ze vaak met gegoede mannen. Liefst laat men haar spoedig na het huwelijk harer meesteres trouwen, en dan zijn hare kinderen gewoonlijk de speelkameraden van die der aanzienlijke vrouw.

Nog bij andere gelegenheden is er sprake van an mamoha. Wanneer een radja stierf waren de bevriende vorsten van andere landschappen gewend aan de familie van den overledene een a $n$ a $m a m o h a$ te geven; deze bleef dan het eigendom van die familie. - Bij de verzoeningsfeesten waren beide partijen gewend elkaar een a na maha te schenken. 
In theorie mag de man zijn vrouw niet naar zijn eigen woning meenemen, zoolang de bruidsschat niet is afbetaald. Zoo is de vrouw van Tana Homba, radja van Lewa, in haar geboorteland Kanatang blijven wonen, omdat de bruidsschat voor haar nog steeds niet is afbetaald. Gebeurt dit niet voordat zij sterft, dan wordt zij ook in Kanatang begraven. Maar gewoonlijk neemt de man zijn vrouw vast mee, en hij zorgt dat de bruidsschat langzamerhand wordt afbetaald. Wanneer de man sterft voordat dit gebeurd is, zorgt zijn broer meestal voor de afbetaling; deze heeft dan het recht de vrouw te trouwen en haar kinderen als de zijne te beschouwen. Is de schuld reeds door den echtgenoot afbetaald, dan kan een zijner broers na zijn dood de weduwe tot vrouw nemen, zonder wederom bruidsschat te betalen. Ook een lid van denzelfden kabisoe mag haar met onderling goedvinden tot zijne vrouw maken, zonder iets te betalen. Komt echter een man uit een ander geslacht om haar, dan moet hij een groot bedrag betalen aan den $\mathrm{kabisoe}$ van den overledene; omdat zij daardoor voor dat geslacht verloren gaat.

Is niemand van de bloedverwanten van den overleden echtgenoot in staat den bruidsschat af te betalen, dan wordt gewacht tot de kinderen groot geworden zijn, en dezen zullen al hunne krachten inspannen om het benoodigde bijeen te brengen, daar het niet afbetaald zijn van den bruidsschat als een schande op hen rust. Bestaat er onwil om te betalen, dan neemt de familie van de vrouw de moeder met hare kinderen weer bij zich op, en zij kan aan een ander worden uitgehuwelijkt, met het weer op nieuw betalen van bruidsschat.

Een andere wijze van huwelijkssluiting is die door schaking, waarvan ik reeds iets gezegd heb in verband met het landschap Kodi. Het schaken van een vrouw schijnt op Soemba vrij veel voor te komen, zoowel in het Westen als in het Oosten. Soms geschiedt het met medeweten der ouders van het meisje. Dit is dan een soort van komedievertooning. Ds. Krijger vertelt in de Groninger Kerkbode van 9 Maart '18, dat zelfs de dorpskinderen er van af weten als zoo'n schaking plaats zal hebben. Ze roepen dan het meisje als ze water of hout gaat halen (bij welke gelegenheid het ontvoeren zal plaats hebben) na: "maisstampen, rijststampen», doelende op de werkzaamheden, die ze als huisvrouw te verrichten zal hebben. Waarom zulk een schaking met medeweten van het meisje plaats heeft, is niet altijd te zeggen. 
Men beweert, dat het meisje zulks wenscht om zich naam te maken. Meer aannemelijk is de reden, dat de jonge man door dit ontvoeren zijn vader wil dwingen om met het bijeenbrengen van den bruidsschat wat voort te maken. Want na een ontvoering is de eenige manier om aan zulk een zaak geen erger gevolgen te geven: den bruidsschat zoo spoedig mogelijk te voldoen.

Heeft de ontvoering plaats gehad, omdat de ouders van het meisje zich tegen het huwelijk hebben verzet, dan geeft de schaker hun kennis, waar hij zich met hun dochter bevindt. Bij de ontvoering heeft het meisje een gouden oorhanger, mamoeli, in haar opgerolde en achtergelaten slaapmat gelegd, en dit moet aan haar ouders duidelijk maken, dat zij geschaakt is, en tevens dient dit sieraad om den eersten toorn der ouders wat tot bedaren te brengen. De vader van het meisje gaat dan naar den schaker, en als hij het niet tot een openlijken strijd wil laten komen, heeft hij zich in het geval te schikken, en alleen te bepalen hoeveel hij als bruidsschat voor zijne dochter wenscht te ontvangen. Wanneer beide jongelui van denzelfden stand zijn, geeft dit geen moeielijkheden, en behalve den bruidsschat betaalt de jonge man nog een boete. $Z$ ijn de twee echter van verschillenden stand dan kan dit moeielijkheden geven. Dit schaken heet in Oost Soemba: palai ngandi, "vluchtend wegbrengen».

Nog een andere wijze van huwen, gelijkstaande aan schaken, heet in Oost-Soemba: tama roembak, "met geweld binnendringen». Zoo iets gebeurt met voorkennis van de moeder van het meisje. De jongeman komt 's avonds als het donker is, te paard aanrijden. Hij bindt zijn rijdier aan een der huispalen vast, en gaat rechtstreeks, zonder iets te zeggen, naar de kamer van het meisje. Daar omhelst hij haar en dan gaan zij samen op de slaapmat liggen. De jongelieden willen hiermee te kennen geven: Als ge ons wilt dooden, dan moet ge het ons samen doen. Wanneer de man niet al te veel in stand verschilt met het meisje, legt de vader van het meisje er zich bij neer, en wordt er over den bruidsschat gesproken.

Het streng doorgevoerde vaderrecht op Soemba kon eertijds niet gedoogen, dat een man van mindere afkomst een kind verwekte bij een dochter van aanzienlijke huize. En toch kwam en komt zoo iets vaak voor; want geheel in strijd met de vaderrechtelijke instellingen is het verkeer tusschen jongens en meisjes heel vrij. De meisjes worden op geenerlei wijze bewakkt, opdat 
zij ongeschonden zouden kunnen worden uitgehuwelijkt. In een geval als pas genoemd is, werd vroeger de man gedood, en het kind (wanneer het meisje er zich niet door afdrijvende middelen van had ontdaan) werd gerekend tot het geslacht der moeder te behooren.

Huwde een aanzienlijke, een van maramba-afkomst met een mindere of slavin, dan werden zijn kinderen gerekend tot de vrijen te behooren. Een slavenkind kan zelfs door een vrije als kind worden aangenomen, waardoor het ook vrij wordt; het kan dan later ook met een vrije vrouw trouwen. Hieruit blijkt weer, wat ik reeds in mijn reisverslag heb aangetoond, dat de vertaling van ata door "slaaf, aanleiding geeft tot misverstand. A ta is het volk, de onvermogenden, die zich onder bescherming van de rijken stellen om door hen beschermd en gevoed te worden.

Vooral in Oost- en Midden-Soemba, waar de vorstenhuizen zijn, kan het voorkomen, dat een radjageslacht dreigt uit te sterven, doordat er alleen dochters zijn. Dan gebeurt het wel, dat uit een ander geslacht, kabisoe, een man "gekocht» wordt, die daardoor naar de kabisoe van den radja overgaat. Deze man, die in stede van bruidsschat te betalen, door een groot geschenk van zijn geslacht wordt losgemaakt, wordt aan een der dochters van het uitstervende huis uitgehuwelijkt. De kinderen uit dit huwelijk worden nog niet voor volle afstammelingen van het radja-geslacht gehouden. Maar wanneer een der zoons later met een maramba-vrouw trouwt en kinderen krijgt, worden deze geheel beschouwd als echte nakomelingen van dien vorst. Zoo is de tegenwoordige radja van Kapoendoek genomen uit Kanatang.

De erkenning kan ook vlugger volgen. Zoo vertelde de Heer Wielenga mij van den radja van Mangili, die van het geslacht Lokoe Nara is. Deze had slechts een dochter, die huwde met iemand uit Lewa. Toen haar man overleden was, nam zij als weduwe een echtgenoot uit Woekoe, een voornaam geslacht in Mangili. Deze man verliet daarvoor zijn familie en werd ta u Lokoe Nara madai oema. Dit paar kreeg een zoon, die dadelijk maramba werd en wettig vorst is.

In nog een ander geval wordt een man "gekocht». Zooals boven is opgemerkt, moeten sommige vorsten uit een bepaalde kabisoe hun hoofdvrouw nemen. Maar nu kan het gebeuren, 
dat op den gewenschten tijd geen meisje in dien $\mathrm{kabisoe}$ ter beschikking is. Dan wordt door het geslacht van den radja een man van die kabisoe gekocht, die daardoor dus overgaat naar het radja-geslacht. Deze man trouwt met een willekeurige vrouw, en de zoon uit dat huwelijk verwekt wordt dan radja; deze moet zorgen later met een meisje uit bedoelde kabisoe te trouwen, dat na zooveel jaren tusschentijd wel zal worden gevonden.

Op Soemba heeft de echtgenoot geen bijzondere égards voor zijn schoonouders. In het noemen van iemands naam ziet niemand op Soemba iets oneerbiedigs, en zoo mag ook de man de namen zijner schoonouders noemen. Het behoort tot den goeden toon niet naar iemands naam, ngara, te vragen, maar naar dien van zijn "naamgenoot", tamoe. Toch is het zaak om zijn schoonouders zooveel mogelijk te ontzien, en aan hun wenschen te gemoet te komen, want als men hen boos maakt, zouden ze later niet mee willen helpen om den bruidsschat voor de zoons van hun dochter bijeen te brengen. Hieruit blijkt dus, dat het niet alleen de bloedverwanten van den vader zijn, die daartoe bijdragen.

De man kan dikwijls genoeg last van zijn aangetrouwde familie hebben. Telkens wanneer zijn schoonvader bij hem op bezoek komt, moet hij hem eenig geschenk geven, en gewoonlijk moet hij ook voor hem of voor broers zijner vrouw, die bij hem binnenvallen, een "beestje slachten om hen te onthalen. Het is ook het recht van de broers der vrouw om van hun zwager geld te leenen, zonder de verplichting op zich te nemen dit terug te betalen. $\mathrm{Nu}$ en dan brengen zij den zwager een of ander geschenk en vragen hem daarvoor in de plaats een paard. Het paard is er niet, maar de zwager belouft er een te zullen zoeken. Na een maand komt de broer der vrouw weer, en brengt iets mede. Hij vraagt hoe het met zijn paard staat. Het is er nog niet, er wordt nog naar gezocht. $\mathrm{Na}$ een maand verschijnt de broer weer totdat hij eindelijk zijn paard heeft losgekregen, want tegen dergelijke taaiheid in het bezoeken kan de Soembanees niet op. En kon de man nu maar op dezelfde wijze te werk gaan tegenover zijn zwagers. Maar dit gaat niet, want alles wat hij van hen leent, is hij verplicht terug te betalen.

Een enkel woord over het erfrecht: Als regel kan men aannemen, dat op Soemba een der zoons, gewoonlijk de oudste, maar in elk geval hij, die in de ouderlijke woning blijft wonen, 
het beheer heeft over de erfenis. De broers en ongehuwde zusters komen met al hun aangelegeheden bij hem, en uit de erfenis helpt hij hen naar vermogen, en naar zijn inzicht. Zijn er alleen dochters, dan neemt de broer van haren vader het beheer der goederen op zich, en handelt daarmede op dezelfde wijze als haar broer zou doen.

Maar er moet eerst een deel van de erfenis af. Bij het overlijden toch hebben alle bloedverwanten iets tot de ter aardebestelling bijgedragen, en daarvoor krijgt elk hunner iets uit de erfenis, wanneer daartoe ten minste genoeg aanwezig is. Dit alles wordt geregeld na afloop van het doodenfeest, het pahili mbola, of pahili kaloemboetoe. Mbola is het mandje waarin een vrouw haar sirihpinang bewaart; de tasch waarin de man dit doet, heet kaloemboetoe. Een van de laatste bedrijven nu van het doodenfeest is, dat de inhoud van het sirihmandje, of de sirihtasch onder de naastbestaanden verdeeld wordt. Daarna worden ook alle gevers en geefsters uit de nagelaten goederen bedacht.

Overspel en Echtscheiding. Wanneer de vrouw overspel doet, wordt de overspeler beboet. Deze boete is niet zoo hoog als ze bij andere volken in den Indischen Archipel pleegt te zijn. In Lewa zou zij bij aanzienlijken vijf paarden zijn. In West-Soemba is de boete voor overspel gewoonlijk een paard en een buffel; de overspeler moet ook een varken geven, dat geslacht wordt bij het ontzondigen (hawari), dat op dezelfde wijze plaats heeft als na het bedrijven van bloedschande. De schuldigen eten van dit varken mee. Bovendien geeft de overspeler nog aan den beleedigden echtgenoot een doek en een vrouwenrok. Verdere gevolgen heeft zulk een daad niet. Aanleiding tot scheiding schijnt overspel niet te geven. Vandaar dat de Heer Barentsen, die jarenlang West-Soemba als gezaghebber bestuurd heeft, in een nota over die streek kon schrijven: «De Soembaneesche echtgenoot schijnt zich weinig aan te trekken van het overspel zijner vrouw; betaalt de verleider de geeischte boete, dan is de zaak weder in orde».

Wil de vrouw van den man af, en den ander volgen, dan is de eenige weg, dat deze de vrouw schaakt, maar dan moet hij behalve een boete, den geheelen voor haar betaalden bruidsschat aan haar echtgenoot terugstorten.

Scheiden met wederzijdsch goedvinden is in een maatschappij 
als de Soembasche ondenkbaar. Heeft de man genoeg van zijn vrouw, dan zal hij toch niet van haar scheiden of haar naar hare familie terugzenden. 'Zoo iets zou hem niet alleen niets verder brengen, maar men verzekerde mij, dat dit als zulk een groote beleediging zou worden opgevat, dat er vroeger oorlog uit zou ontstaan zijn. Eenvoudiger is het er een tweede vrouw bij te nemen.

Slechts van één officieele echtscheiding wist de Heer Wielenga te vertellen. De Heer Streiff, luitenant der Infanterie, had de heele plechtigheid bijgewoond, en het verloop er van aan den Heer Wielenga medegedeeld, die het verhaal weer aan mij heeft overgedaan. Het gold hier de zoon van den radja van Kambera, die met een dochter van den radja van Melolo gehuwd was. Deze vrouw had overspel gepleegd en de man was niet onverschillig geweest voor zijn eer en eischte van haar gescheiden te worden. Ook de betaalde bruidsschat werd teruggevraagd. Heel de wereld kwam er bij te pas.

Beide partijen kwamen bijeen in de oema andoeng, het huis waarvoor de andoeng staat, de paal, waarop de gesnelde koppen worden geplaatst. Twee bakjes waren gereed gemaakt, waarin sirih-pinang, goudschilfertjes ( $\mathrm{kaw} a \mathrm{dăkoe}$ ), en een lap katoen. In het eene lagen nog een hakmes en een mes. Dit was bestemd voor den marapoe wai maringoe, den geest van het koele water, die hier den naam draagt van Lai leming terong langoe. Het andere mandje was voor den marapoe van de oema andoeng; deze draagt den naam van Lai kaka ngoeroe.

Ook het water waarmee afgekoeld zou worden, werd gereed gezet; een paar kokosdoppen waarin stukjes van de wala kandangoe, een plant waarop water gegoten wordt. Ook de familie-marapoe, die bij alle dagelijksche zaken wordt aangeroepen, en die den naam draagt van marapoe oema hamaja ng, de marapoe van het bidhuis, krijgt zijn deel in sirih-pinang. Verder wordt een offer van kauwingredienten met een goudschilfertje er bovenop voor den $\mathrm{m}$ arapoe tana, den geest van den grond, voor de woning geplaatst, waarbij hemel en aarde worden aangeroepen, om deze kennis te geven, dat men thans de schande en het kwaad, die het gevolg van de echtscheiding zouden kunnen wezen, van zich doet. Dan werd in de voorgalerij door den bewaker van de marapoe gebeden. Hij had daarbij een kuiken in de hand, dat na de aanroeping geslacht 
werd. De ingewanden er van werden bekeken, en de teekenen er aan gunstig bevonden. Ook een hond, die klaar gehouden was, werd toen dood geslagen. Diens lever werd uit het lijf gehaald, en in een bakje met rijst gelegd. Daarna werd het verkoelende water uitgestort, boeri wai maringoe, wai malala, "uitgieten koud water, opgelost water». Ten tweede male werd wat rijst gevoegd bij de lever van den hond en de ingewanden van de kip, waarbij alles den marapoe werd aangeboden om daarvan te eten. Wanneer ondersteld werd dat ze hiermede gereed waren, werd de bak waarin de ingewanden lagen, buiten op den grond gezet.

$\mathrm{Na}$ afloop hiervan werd gekookte rijst in eenige kokosdoppen geschept, en deze nappen werden met het lijf van den gedooden hond naar het huis gebracht, waar de marapoe tana, de geest van den grond, wordt vereerd. Dit werd dezen geest te eten aangeboden met eene aanroeping. Het vleesch van den hond werd niet gegeten, maar het kadaver werd weggeworpen.

Toen men weer in huis teruggekomen was, waar allen bijeen waren, werd weer gebeden en een hoen geslacht om uit zijn ingewanden op te maken of de marapoe voldaan waren. De verzorger van den marapoe andoeng gaf uit naam van dezen aan den bewaker van den marapoe tana sirih pinang met een goudschilfertje, en dit offer werdt op dezelfde wijze door den laatste beantwoord ten behoeve van den marapoe andoeng. Die uitwisseling van offers tusschen de beide marapoe's door tusschenkomst hunner bewakers had viermaal plaats, waarna de schuldigen met verkoelend water werden begoten.

Om de kwade gevolgen voor den veestapel en het gewas te vernietigen, werd ook een goudschilfer geofferd aan den marapoe ndjara, voor de paarden en de buffels; een voor den marapoe van de varkens en kippen; een voor den marapoe van den akker. Maar ook de leider zelf van de plechtigheid kon kwaad ondervinden van zijn werk, en daarom werd ook voor hem een goudschilfer geofferd. Ten slotte werd rijst gestrooid voor de woning van den $\mathrm{m}$ arapoe oema andoeng, en voor het verblijf van den marapoe tana, en kreeg ieder der bewakers een kip, die zij levend mochten meenemen.

Nadat op de boven beschreven wijze de geestelijke machten tevreden gesteld waren, moesten ook de staatkundige machten met de echtscheiding worden verzoend. Daarvoor trad een welgestelde huisvader op, een zoogenaamde a ma bokoel "groote 
vader", die tot den marapoe van Watoe pelitoe, het onderdeel van Melolo, waaruit de vrouw afkomstig was, bad. Te zamen met dit gebed verrichtte hij het wichelen door middel van de lans om na te kunnen gaan of de aangeroepen marapoe tevreden was. Weer werden aan marapoe tana en marapoe wai maringoe offers aangeboden, ieder een bakje met sirih-pinang, en een koperen ketting, kan atar.

Daarna werd er een veulen voorgebracht. De a ma bokoel riep nu weer den marapoe aan met behulp van de lans, waarna hij het dier slachtte. Een kip werd dadelijk daarop gedood om uit de ingewanden te zien, of het offer was aangenomen, omdat de levers van paarden niet worden onderzocht. Ten slotte moest ook een buffel voor deze gelegenheid het leven laten. De bewakers van marapoe oema andoeng en die van marapoe wai maringoe kregen toen weer ieder twee hoenders, waarvan zij een offerden en de andere levend meenamen. De harten van al de geslachte dieren werden in een bak gelegd, daaraan werd rijst toegevoegd, en dit alles werd te eten aangeboden aan den marapoe van Watoe pelitoe, marapoe wai maringoe en mara poe oema andoeng. Daarbij werd op de heilige gongs geslagen om de marapoe's tot den maaltijd te roepen. Toen ondersteld werd, dat ze met eten gedaan hadden, hield men op met slaan en werden de gongs weer in huis gebracht.

Het slot van alles was, dat twee kippen werden geslacht om uit de ingewanden na te gaan of alle onzichtbare machten nu tevreden waren. De ingewanden echter zeiden, dat dit niet het geval was. Toen werden opnieuw twee hoenders geslacht, maar ook hun ingewanden zeiden den offeraars, dat de zaak niet in orde was. Toen werden de marapoe aangeroepen: "Hebt medelijden met ons, weest niet toornig, want de bevelhebber van het heele land is hier tegenwoordig». Daarna beproefde men het weer met twee kippen, en de geesten hadden zich laten vermurwen en lieten den menschen door de ingewanden der vogels weten, dat ze bevredigd waren.

$\mathrm{Z}$ wangerschap en Geboorte. Wanneer een echtpaar reeds eenigen tijd gehuwd is, en nog geen kind heeft, worden verschillende offers gebracht aan den familie-marapoe. De vrouw gaat daartoe naar hare ouderlijke woning. In Laura heet dit figuurlijk: "om mais en rijst te vragen». Een dier wordt bij deze gelegenheid geslacht, en door middel van het wichelen 
met de speer tracht men te weten te komen of de wensch van de vrouw vervuld zal worden. Heeft de speer gunstig voorspeld, dan gaat de vrouw naar hare woning terug; in Laura krijgt zij in verband met boven medegedeelde uitdrukking den wensch mee, dat de mais en de rijst bij haar evengoed mogen gedijen, als ze dit bij haar ouders hebben gedaan.

Anderen nemen tot meer radicale maatregelen hun toevlucht. Wanneer de man namelijk vermoedt, dat de reden van de kinderloosheid aan hem ligt, dan verzoekt hij een kabisoe-genoot, die veel kinderen heeft, ook een kind voor hem bij zijn vrouw te verwekken. Meestal wordt zulk een hulpbetoon geheim gehouden, vooral in geval een radja op deze wijze hulp heeft gezocht om een troonsopvolger te krijgen; wanneer toch het volk kennis kreeg van het gebeurde, zou het wel eens bezwaar kunnen maken, dien zoon als vorst te erkennen. Maar overigens schaamt men zich niet hiervoor. Oemboe Dong van Anakala beroemde er zich op, dat hij reeds velen zijner kabisoe-genooten aan een kind had geholpen. Het behoeft nauwelijks gezegd, dat dit kind gerekend wordt te zijn van het echtpaar.

Gedurende den tijd der zwangerschap wordt er nu en dan aan den marapoe geofferd, opdat deze zal meewerken -om de bevalling voorspoedig te doen verloopen. In Laura wordt dit weer met de volgende beeldspraak uitgedrukt: om de aarde rondom de rijst en de mais op te hoogen, en om het pak met sirih-pinang open te maken. Het ophoogen van aarde om boomen en planten geschiedt met de bedoeling ze sterker te doen groeien; bij rijst en mais heeft dit ophoogen niet plaats, maar zooals we zagen is "mais en rijst» een uitdrukking voor "kind». Het offer moet dus dienen om het kind voorspoedig te doen groeien. De tweede beeldspraak duidt op de pakken sirih-vruchten en pinangnoten, die in de bladscheede van den pinangboom worden gewikkeld, daarna stevig met touw, rotan of boombast worden vastgebonden, en op deze wijze vervoerd. Het losmaken van zulk een pak bedoelt dus: dat het kind los worde in den moederschoot, opdat het later zonder eenige moeite ter wereld zal worden gebracht.

Een poos later heeft dan weer een offerplechtigheid plaats om de ruimte onder het huis af te sluiten. In die ruimte toch houden zich gaarne allerlei geesten en booze machten op, die de zwangere vrouw in haar bijzonderen toestand gemakkelijk 
kwaad kunnen doen; die kwade invloeden moeten verwijderd of verre gehouden worden.

Zooals te verwachten is, kent de Soembanees tal van voorzorgen, die de aanstaande moeder in acht moet nemen, ten einde een welgeschapen kind ter wereld te kunnen brengen. In sommige streken mag de man niet meer bij zijn vrouw komen, als het zeker is, dat ze zwanger is. Hij spreekt haar dan aan met ana wini, "zuster» en zij zegt tot hem ana moni (moni, "mannelijk»). $\mathrm{Z}_{\mathrm{ij}}$ mag niet in de deur zitten, want dan zal ze later geen zog hebben voor de kleine. $\mathrm{Ze}$ mag een verzoek niet met "niet» of "neen» beantwoorden, want dit zou haar in haar bijzonderen toestand kwaad doen. Wanneer de tanden der aanstaande moeder nog niet gevijld zijn, mag dit niet tijdens haar zwangerschap gedaan worden, want dan zou het kind doodgaan; ook de aanstaande -vader moet het vijlen zijner tanden uitstellen, wanneer dit niet voor de zwangerschap zijner vrouw is geschied. - Allerlei dingen zijn voor de vrouw verboden te eten: geen inktvisch, omdat het kind anders vingers zou krijgen als de armen van dit dier; geen schildpad omdat anders zijn lichaam op dat van zulk een beest zou lijken, enz.

Verschillende voorschriften gelden voor man en vrouw samen: zij mogen zich het haar niet laten korten; zij mogen niet eenig dier slachten. Weer andere bepalingen worden alleen door den man in acht genomen. Verschillende dingen mag hij in dezen tijd niet maken: geen kom, omdat het kind anders vingers met stompe knobbels er aan zou krijgen; geen handvat voor zwaard of mes, omdat het kind anders een krommen arm zou krijgen; geen lepel uit kokosdop mag hij snijden, omdat het kind anders leelijke platte ooren zal hebben; geen vork van bamboe met twee punten maken, want anders zal het kind met een gespleten vinger in de wereld komen; geen kokosdop glad schuren of krabben om daarvan een drinknap te maken, omdat het kind dan geen hoofdhaar zou hebben. De man mag geen brandhout hakken, anders zal het kind verminkt ter wereld komen; geen touw draaien, anders zou het handen en voeten niet kunnen bewegen; geen gaten boren, anders zou het kind met gaten (wonden) in het hoofd, of met een hazelip geboren worden. Wanneer hij eet moet hij hoofddoek en sirihtasch afleggen om een voorspoedige bevalling te bevorderen. Hij mag niet veel kleeren over elkaar dragen, omdat het kind hierdoor niet spoedig 
ter wereld zou komen; hij mag ook niet veel praten, want dit zou ten gevolge hebben, dat het kind later veel zal huilen.

Al deze voorschriften heb ik in verschillende landschappen vernomen, en ik heb ze samengebracht zonder speciale vermelding van de streek, waar men ze mij mededeelde, omdat ze alle uitdrukkingen zijn van dezelfde gedachte.

De Soembaneesche vrouw bevalt in zittende houding. Een oudere vrouw, die door de praktijk ervaring heeft opgedaan in dit werk, staat haar bij. In Lakoka vertelde men mij, dat de vrouw zich bij voorkeur aan den hoofddoek van den man vasthoudt, waartoe het uiteinde van den doek aan een dakspar is vastgemaakt. Dit zal op andere plaatsen ook wel zoo zijn.

Gaat de bevalling moeielijk of duurt het lang, voor dat het kind er is, dan schrijft men dit aan geen andere reden toe dan aan de omstandigheid, dat de vrouw overspel heeft gepleegd. Wanneer zij dit bekent wordt ze "ontzondigd» (hawari) op de wijze, zooals boven beschreven is bij bloedschande. Daarna zal het kind spoedig geboren worden, denkt men. Of de aanstaande vader lokt het kind naar buiten door te zeggen: «Kom maar gauw, want hier zijn je zwaard, je schild en je speer; of: hier zijn je kookpot en je watervat,; want de kleine kan evengoed een jongen als een meisje zijn. Sterft de vrouw voordat het het kind geboren is, dan zegt men, dat zij een belofte heeft afgelegd om haar kwaad nooit te bekennen, zoodat ze daaraan gestorven is. Het lijk van een in het kraambed gestorvene wordt zonder eenige voorzorg begraven; het wordt juist zoo behandeld als andere dooden. Een kraamvrouwenspook, dat het zwangere vrouwen lastig maakt en haar bedreigt, kent de Soembanees niet. Is het kind in leven wanneer de moeder sterft, dan wordt het wicht niet met de moeder begraven, maar een andere zoogende vrouw tracht het in het leven te behouden.

Wanneer een kind in de voetligging geboren wordt, gelooft men dat de moeder iets op haar geweten heeft. Overigens doet men geen voorspellingen uit de houding, waarin het kind geboren wordt. Overal op Soemba zegt men van een meisje, dat met het aangezicht naar boven geboren wordt: " $\mathrm{Zij}$ zoekt een man». En van een jongen, die met het aangezicht naar beneden ter wereld komt: "Hij zoekt een vrouw».

Tweelingen schijnen nog al eens voor te komen. De geboorte van een tweeling wordt niet beschouwd als een onheil aan- 
brengende gebeurtenis. $\mathrm{Zijn}$ de kinderen beide jongens of beide meisjes, dan verheugt men zich in de tweelingen. $Z$ ijn ze echter van verschillend geslacht, dan wordt het paar over geheel Soemba minder gunstig ontvangen. Zulk een geval wordt dadelijk "verkoeld» (hawari) op de wijze waarop dit in geval van bloedschande geschiedt. Men denkt dat tweelingen van verschillend geslacht niet lang kunnen leven. In Oost-Soemba wordt een der twee aan een ander familielid ter opvoeding gegeven. In WestSoemba blijven ze bij elkaar, maar dan wordt nu en dan een offer voor hen aan den familie-marapoe gebracht, om het kwaad dat aan hen kleeft, verder van hen af te doen, opdat ze niet zullen sterven. Deze offers en gebeden worden herhaald, totdat beide kinderen groot zijn geworden, en het niet waarschijnlijk meer is, dat ze zullen sterven.

Op mijn vragen naar drielingen, antwoordde men in Lakoka nog nimmer van zulk een geval gehoord te hebben. De radja's van Bolobokat en Napoe wisten, dat dit in hun gebied eenmaal is voorgekomen, maar de kinderen waren spoedig gestorven. In Anakala had men nooit van drielingen gehoord, en in Wajewa was één geval daarvan bekend.

Zoodra ook de placenta te voorschijn is gekomen, wordt de navelstreng op twee, drie vingers breedte van het lichaam van de kleine doorgesneden met een bamboesplinter. Niets wordt daarbij tot steun onder de navelstreng gehouden. $\mathrm{Zij}$ wordt ook van te voren niet afgebonden. Men laat de wond eenvoudig uitbloeden. De placenta die op Soemba "de oudere broeder» wordt genoemd (een enkele maal slechts "de jongere broeder»), wordt soms in een mandje gedaan en in een boom opgehangen, of in een holte er van geplaatst; soms wordt zij begraven, hetzij onder de trap, hetzij bij een pisang boom. Ieder gezin volgt hierin de wijze, die het van ouder tot ouder gewend is geweest. Wanneer men gewoon is de placenta te begraven, en vele kinderen uit zulk een gezin sterven, dan brengt men de nageboorte bij een volgende bevalling wel naar een boom. Anderen verzekerden mij, dat zij zich aan zoo iets niet storen en op dezelfde wijze voortgaan de placenta te behandelen al sterven er van hun kinderen.

Alleen in Laura gaat het eenigszins anders toe. Daar wordt de placenta in een kokosdop gelegd, die geplaatst wordt in de opening van een peperhuis, dat van kokosblad is gevlochten. 
Dit peperhuis wordt met de punt op een in den grond geplanten staak bevestigd, en zoo laat men de nageboorte aan haar lot over. Alleen wanneer het kind veel huilt, gaat men kijken of er mieren op de placenta zijn; deze worden dan verwijderd.

Dadelijk na de bevalling wordt de kraamvrouw bij het vuur geplaatst met den rug er naar toe. Dit moet zij volhouden tot het eindje navelstreng aan de kleine verdroogd en afgevallen is, dus zes tot tien dagen. Dan wordt ook het haar van de zuigeling voor het eerst gesneden. Een deel er van wordt in een kokosdop gedaan, waaraan asch en houtskool worden toegevoegd. Dit alles wordt vervolgens naar het Westen weggeworpen. Eerst daarna mag de kraamvrouw weer het gelaat naar het vuur toekeeren, maar gedurende een maand of zes moet zij zich daarbij blijven warmen, en wordt zij iederen dag met lauw water gebaad; in dat water worden vooraf eenige bladeren gedaan, waaronder die van tamarinde. Het overige van het hoofdhaar van de kleine wordt te zamen met het verdroogde stukje navelstreng goed bewaard, tot dat het kind, volwassen geworden, gehuwd is. Hoe het bij die gelegenheid soms nog dienst moet doen, hebben we boven gezien. Zijn ze niet meer noodig, dan worden ook deze dingen bij een pisangboom begraven.

Dadelijk na het afsnijden van het eerste hoofdhaar gaat de moeder met de kleine naar beneden. Bij deze gelegenheid wordt natuurlijk gebeden en geofferd. Degeen die het haar gesneden heeft, ontvangt een deel van het vleesch der kippen, die worden geslacht. Bij deze gelegenheid ontvangt ook de vrouw, die bij de bevalling geholpen heeft haar loon, dat niet overal hetzelfde is. In Laura en Wajewa worden een kluwen garen, een hoen, een mes en een koperen vingerring gegeven.

Wanneer de moeder de kleine voor het eerst naar de rivier meeneemt, moet zij bijzondere voorzorgen nemen. Dit geschiedt echter pas later, wanneer het kind begint te loopen. In Lakoka neemt ze bij deze gelegenheid mee: sirih-pinang, een stuk kokosvleesch en een mes. $\mathrm{Na}$ het bad van de kleine laat zij de genoemde dingen daar achter, alleen het mes neemt zij weer mee naar huis.

Een naam wordt al vrij spoedig aan het kind gegeven. Op allerlei wijze laat men het zijn eigen naam kiezen. In vele streken gebeurt dit op den geboortedag. In Kambera noemt men eenige namen achter elkaar op, wanneer de navelstreng is afgesneden, Dl. 78. 
die zooals wij gehoord hebben, niet is afgebonden. Houdt bij het noemen van een naam het bloeden op, dan wordt die naam aan het kind gegeven. In Wajewa kauwt eene der verwanten kokos, en bevochtigt daarmee den vinger, waarna ze dien in het mondje van het pas geboren kind steekt. Ook nu worden eenige namen genoemd, en die waarbij het kind aan den vinger begint te zuigen, acht men den meest gunstigen. In Laura legt een der aanwezige vrouwen tot het zelfde doel het kind aan de borst, terwijl de vader eenige namen noemt. Wielenga geeft in de Macedoniër (XII, 1908, bl. 301 e.v.) een verhaal, waarin verteld wordt van een gestorven grootvader, die bij het naam-raden voor zijn kleindochter bij iederen naam ook een doodsoorzaak noemt: dat zij door een slang gebeten zal worden, dat regen haar koortsen zal bezorgen, waaraan zij zal sterven; dat haar vader en haar man zullen gaan jagen, en dat dezen thuis gekomen, haar begraven zullen vinden. Bij het noemen van den derden naam was het bloed opgehouden te vloeien uit de navelwond; het meisje zou dus dien naam dragen, en daarmede was ook de wijze, waarop zij zou sterven bepaald.

De Heer Canisius was zoo vriendelijk mij een paar stamboomen te geven van de geslachten der bestuurders van Lauli en Lamboja. In deze lijsten van namen valt het op, dat zekere namen telkens in de familie terugkeeren. De zoon zal nooit denzelfden naam als dien van zijn vader dragen, maar gewoonlijk heeft hij dien van zijn grootvader of van een broer van dezen. Ook komt het voor, dat soms zoons van denzelfden vader, maar van verschillende moeders, denzelfden naam dragen. Dit is vrij wel regel op Soemba, dat men een kind den naam geeft van zijn grootvader of grootmoeder, of in elk geval den naam van een marapoe-stamverwant. Boven heb ik reeds opgemerkt, dat men zich voor het noemen van zijn eigen naam niet schaamt. Alleen vraagt men naar iemands "naamgenoot", in plaats van naar zijn "naam».

Besnijdenis. Wanneer de Soembaneesche jongen den leeftijd heeft bereikt, dat hij aan trouwen gaat denken, wordt hij besneden. In Oost-Soemba heet dit kari, in Wajewa kamatoeka, maar meestal duidt men deze handelingen aan door eene omschrijving, zooals poeroe la wai (Kambera), poeroengoe ta wai (Lakoka), «in het water afdalen», of: lomboe keloe (Lakoka), salakoe liboe kalo (Wanoekaka, Lauli), "onder 
de pisang . Beide uitdrukkingen duiden op de omstandigheden waaronder de besnijdenis plaats heeft: de jongens worden daartoe in een tuin gebracht, die bij het water gelegen is, of het gebeurt onder een pisangboom, wiens verkoelende invloed moet zorgen, dat na de operatie geen ontsteking ontstaat.

De besnijdenis heeft meestal na den tweeden maisoogst plaats, dus in den tijd van Juli totdat de regens weer inzetten. In den natten tijd is het niet geraden iemand te besnijden, want dan zou de wond niet snel genezen. Meestal worden eenige jongens tegelijk geopereerd, maar hun aantal moet steeds even zijn. Zijn er geen knapen genoeg om hun getal even te maken, dan wordt een pisangstam gelegd in het huisje waarin zij verblijven om hun aantal even te maken. In dien pisangstam wordt bij de operatie ook een insnijding gemaakt. In West-Soemba wordt op een even getal jongens minder gelet.

Het is meestal een man op leeftijd die de jongens besnijdt. Hij brengt daartoe een stukje kokosdop of hout onder de voorhuid, en klooft daarop het vel met een mes. De jongen, die voordat deze operatie aan hem is verricht, bij meisjes is geweest, moet dit vooraf aan den operateur bekennen. Deze roept dan den marapoe aan en slacht een kip, waarop een schilfer goud wordt gelegd. Had de jongen niet vooraf bekend, dan zou de wond sterk zijn gaan bloeden. Wanneer de wond van een knaap, die nog niet bij meisjes is geweest, sterk bloedt, bekent hij toch dit te hebben gedaan, opdat het bloeden op zal houden. De operateur ontvangt van iederen jongen, dien hij heeft besneden een oorhanger, mamoeli. In deze voorwerpen bestaat zeer groote verscheidenheid, zoodat de prijzen er van ook zeer varieeren. In Wajewa krijgt de operateur alleen het mes waarmee hij het werk heeft gedaan, en dat hem door de ouders van den jongen is verstrekt. De gewonde penis wordt tegen den buik gebonden met medicijn er op. Gewoonlijk blijft hij drie dagen lang in deze positie. Alleen wanneer de patient moet urineeren, wordt de penis los gemaakt. Hij moet echter oppassen, dat geen urine de wond raakt, want anders zou deze zich niet sluiten.

De jongens moeten op den rijstakker blijven tot de wond genezen is. Vrouwen en meisjes mogen daar niet bij hen komen. De jongens mogen alleen koude spijzen gebruiken, daar warm voedsel de spoedige genezing zou tegenhouden. Een eigenaardige gewoonte zoowel in Oost- als in West-Soemba (alleen in Wajewa 
zei men gebeurt het niet) is, dat de jongens tijdens hun verblijf in de hut een dier gaan stelen om dit voor zich te bereiden. Meestal zijn het kippen, die ze nemen, maar vaak ook een varken, en als er zoons van aanzienlijken bij zijn, steelt men wel een buffel en slacht dien. De eigenaar van het dier mag er niets van zeggen. Op z'n hoogst kan hij zijn zoon, wanneer deze later besneden wordt, opdragen een buffel te stelen van de familie van jongens, die indertijd den zijnen hebben genomen, om zich op deze wijze te wreken. Deze gewoonte noemt men lo pamanganga. Wanneer ze het vleesch van het gestolen beest gegeten hebben, keeren ze naar het dorp terug. Een reden voor dit gebruik wist men mij niet op te geven. Het antwoord was steeds: het dier wordt gestolen, opdat allen in den omtrek zouden weten, dat er een besnijdenisplechtigheid heeft plaats gehad.

Overal zei men mij, dat alle jongens zonder onderscheid besneden worden. Op de vraag welk kwaad er uit zou voortkomen, als dit werd nagelaten, antwoordde men dat een man beschaamd is niet besneden te zijn; of: dat geen vrouw dan met hem wilde huwen; of: dat zijn kinderen dan allen zouden sterven. De radja van Manoekaka zei mij, dat een man die niet besneden is, niet in Parai Marapoe, het zielenland wordt toegelaten.

Overal op Soemba verzekerde men mij, dat de besnijdenis een oeroude instelling is, die niet is ingevoerd. Met het korten der tanden, een gebruik, waaraan het meisje en de jongen zich eveneens tegen den tijd der puberteit onderwerpen, is dit anders. Terwijl deze gewoonte in Oost-Soemba als oorspronkelijk wordt voorgesteld, en in Kodi en in Laura in het Westen eveneens, weet men in het binnenland van West-Soemba nog heel goed, dat dit gebruik eerst later in z.wang gekomen is. Het hoofd van Elo Pada (Wajewa) vertelde mij zelfs, dat pas gedurende het leven van zijn vader de menschen in die streek begonnen waren zich de tanden te laten korten, en in het landschap Wajewa moeten er zelfs nu nog velen zijn, die hunne tanden nog gaaf hebben. Het sirih-pinang-kauwen echter heeft men al langer gekend. De Soembanees is een hartstochtelijk sirihpruimer, in 't Oosten meer dan in 't Westen. Met het rooken van tabak is men eerst in den jongeren tijd begonnen, en de Soembanees schijnt het over 't geheel niet graag te doen.

Zoowel van de boven- als van de onderkaak worden de tanden 
gekort. Dit geschiedt met een mes, waarin tanden zijn gehakt; tegenwoordig doet men het wel met een vijl. Als de zenuw naar buiten treedt, wordt deze met een roodgloeiend gemaakte naald gebrand. Ook bij het tanden korten is het geraden om, als men huwelijksgemeenschap heeft gehad, dit vooraf te bekennen, want anders zouden er wel eens hevige bloedingen kunnen ontstaan. Van eenige verfstof om de tanden zwart te maken weet men niet. Door de inwerking van sirihvocht en kalk worden de stompjes tand vanzelf donker gekleurd.

Wanneer de tanden pas gevijld zijn, appliceert men er jonge sirih op; daarna mag men weer alles eten. De afgevijlde eindjes tand worden bij een pisangboom begraven. Een reden waarom de tanden gekort worden wist men mij niet op te geven. In Lakoka onderstelde men, dat de tanden anders op den duur te lang zouden worden.

Lijkbezorging. Aangezien de gebruiken bij de lijkbezorging van veel belang zijn bij het onderzoek naâr de vreemde invloeden, welke op een volk hebben ingewerkt, moeten deze hier zoo nauwkeurig mogelijk worden nagegaan. Die gebruiken wijken in de verschillende landschappen in onderdeelen van elkaar af. In $\mathrm{Ka}$ mbera wordt het lijk aangekleed en in zittende houding op de algemeene rustbank in het voorhuis geplaatst: de knieën zijn tegen de buik opgetrokken; de armen worden over de borst gekruist, zoodanig dat de handen onder de kin komen te liggen. In de handen plaatst men een halve kokosnoot, waarin de kin komt te liggen. De kokosdop met vleesch wordt waarschijnlijk mede gegeven, opdat de doode er zich in het Hiernamaals het hoofdhaar mee zou kunnen wasschen. Het lichaam wordt in doeken gewikkeld, waaronder soms zeer kostbare. Hoe rijker iemand is, hoe meer doeken om zijn lijk gaan. Het hoofd blijft onbedekt; alleen wanneer zich na een paar dagen teekenen van ontbinding vertoonen, wordt het wel met een doek toegedekt.

De lijken van voorname lieden worden na vijf dagen begraven. Vorsten worden daartoe eerst in een groote vierkante kist gelegd, kabang ${ }^{1}$ geheeten, waarvoor men in de buurt van

\footnotetext{
${ }^{1} \mathrm{Kab}$ ang is wrsch. id. met Mentaweisch abang, „boot”, en Ment. kalabba, Niassisch kalamba, ,vaartuig": ka la mba is ook de naam der groote steenen urnen in de Berglandschappen van Midden-Celebes, waarin beenderen van gestorvenen werden bijgezet. De doodkist wordt vaak als vaartuig beschouwd. (Adriani).
} 
plaatsen als Waingapoe en Melolo wel een zinken of blikken kist aan Chineesche of Arabische handelaren vraagt; in zulke kisten worden vaak goederen als lucifers en dergelijke verzonden. De lijken van andere personen gaan alleen in doeken gewikkeld in het graf. Dit is rond uitgegraven in den grond. Als het lijk daarin is neergelaten, wordt dit met water en asch besprenkeld, wat sirih-pinang wordt er bij geworpen, waarna de kuil met een steen wordt toegedekt.

Aan het lijk worden soms kostbare sieraden meegegeven, vooral oorhangers, mamoeli, die in plooien der doeken worden gelegd. Op het graf wordt een droge buffelhuid gelegd, waarop eenige slaven en slavinnen, die opzichtig zijn aangekleed, plaats nemen. In vroegere dagen werden deze slaven gedood, geworgd. Zoo vertelt Wijngaarden (Mededeelingen Ned. Zend. Gen., 37, 1893, blz. 273), dat bij den dood van een radja van Melolo tien slaven werden gedood. Tegenwoordig geschiedt dit natuurlijk niet meer, maar bij iedere begrafenis moeten deze lieden, papangga geheeten, tegenwoordig zijn.

Bij Lambanapoe vẹrtelde Wielenga, zijn tal van oude graven te vinden. De meesten behooren toe aan gewone menschen en zijn hieraan te herkennen, dat de tombe alleen uit op elkaar gestapelde steenen bestaat. Een dezer grafsteden heeft de gedaante van een huis, en in Kambera vertelt men, dat dit het model zou zijn geweest, waarnaar men de tegenwoordige woonhuizen heeft gebouwd. Wie in dat graf begraven ligt, weet men niet meer.

Zoolang het lijk boven aarde staat, mag in het sterfhuis niet worden gekookt; het vuur moet zelfs dadelijk worden gedoofd, nadat de doode den laatsten adem heeft uitgeblazen. De naaste verwanten eten gedurende de eerste dagen na het overlijden weinig of niets, omdat zij voorgeven hun gedachten geheel aan den doode te willen wijden. Het is evenwel niet verboden het in het huis van de buren te gaan gebruiken, wat dan ook wel gebeurt.

Bij de teraardebestelling worden steeds eenige dieren geslacht, waarvan de Soembaneezen zelven echter niet mogen eten; alleen wanneer er vreemdelingen (Rotineezen, Savoeneezen) tegenwoordig zijn, maken dezen zich van het vleesch meester.

Lewa Pakoe. Wanneer in Lewa Pakoe iemand gestorven is, wordt het lijk gewasschen. Hiervoor is geen bepaald persoon 
aangewezen. Een vrouw zal door haar man, haar moeder, haar dochter of een andere verwante worden gereinigd; het lijk van een man wordt door een mannelijk familielid gewasschen. De knieën van het lijk worden niet opgetrokken. In zijne gestrekte houding wordt het niet in doeken gewikkeld, maar daarin verpakt: bij arme lieden in één enkel stuk, bij rijken in meerdere. Die doeken worden op vier plaatsen om het lichaam vast gebonden: onder de voeten, boven het hoofd, over de borst, en over knieën en buik. Liefst scheurt men die banden af van een ouden hoofddoek, die altijd van boomschors is gemaakt; ander materiaal dat bij de hand is mag ook daarvoor gebruikt worden. Op deze wijze verpakt, wordt het lijk op de algemeene rustbank in huis gelegd met de voeten naar den haard gekeerd. Tusschen het lijkkleed worden enkele oorhangers, mamoeli, gelegd, of ook zet men deze, in een mandje of pot gedaan, afzonderlijk bij in het graf. Het stelen van zulke gaven uit een graf wordt als een zware misdaad aangerekend. Vroeger werd zoo'n grafschender onverbiddelijk gedood; als hij levend gepakt werd, wurgde men hem of knuppelde hem dood.

De grafkuil is langwerpig vierkant uitgegraven. Er overheen te stappen zou als een beleediging den doode aangedaan worden beschouwd. In den kuil te spuwen is evenzeer verboden. Op den bodem er van wordt een platte steen gelegd, daarop plaatst men het lijk, en daarover gaat weer een platte steen. Om het lijk worden steenen opgestapeld. (Een houten lijkkist wordt in Lewa nooit gebruikt). Over de versieringen, die men op en bij het graf aantreft heb ik reeds een en ander in mijn reisverslag in het Tijdschrift van het Kon. Aardrijkskundig Genootschap medegedeeld. Menigmaal vindt men aan de uiteinden der graven steenen opgericht. Nieuwenhuis herkende in den steen aan het hoofdeneind een gestijleerden staart van een haan (Tijdschrift K.N. Aardr. Gen., 2e serie, deel 37, 1920, bl. 510). Bij andere graven meen ik in den steen aan het hoofdeneind een hanekop te herkennen. De haan speelt bij de begrafenisgebruiken der Soembaneezen een voorname rol.

Wanneer men na de begrafenis van het graf weggaat, legt men eerst nog sirih-pinang daarop neer. De mannen die het lijk hebben weggebracht, worden bij hun terugkomst in het dorp, door de meisjes met water geworpen (dit heeft ook in Kambera plaatst); het geschiedt gewoonlijk onder groote vroolijk- 
heid. Gedurende vier dagen na de begrafenis worden nog iederen morgen en avond sirih en pinang naar het graf gebracht.

$\mathrm{Bij}$ de teraardebestelling van een aanzienlijk mensch is er ook nog een man of een vrouw, soms een man en vrouw, die met de oogen dicht aan den kant van het graf ligt. Dit is weer de bovengenoemde papangga. Zoo iemand wordt bij de begrafenis in schijnbaar bewusteloozen toestand achter het lijk aangedragen; hij houdt een levenden haan onder den arm vast. Na afloop van de begrafenis wordt hij weer in denzelfden toestand naar huis gedragen, waar hij dan langzamerhand weer tot zichzelf komt. Behalve deze papangga zijn er nog een man en een vrouw (bij radja's twee mannen en twee vrouwen), die gedurende eenige dagen het graf moeten bewaken. Iederen morgen ook wordt het paard van den overledene om het graf heen geleid, bereden door een fraai uitgedoschten man.

De weduwe van den overledene onthoudt zich in de eerste dagen na het sterven van alle voedsel. Alleen wanneer zij het niet kan uithouden van den honger, mag zij iets gebruiken, maar daartoe moet zij zich naar een ander huis begeven. Aan hen die het lijk bewaken, terwijl het nog boven aarde staat, wordt geregeld te eten gegeven. Ook wordt herhaaldelijk spijs bij den doode neergezet. De weduwe draagt geen bepaalde rouwkleeding; hare sieraden behoeft ze niet af te leggen; na haar vrijwillige onthouding in den eersten tijd, mag zij alle soort van voedsel gebruiken; zij blijft zooveel mogelijk in huis, maar tot het doen harer behoeften begeeft ze zich naar buiten. Ongeveer na een jaar mag zij weer hertrouwen.

Lakoka. In Lakoka wordt het lijk mooi aangekleed, waarbij een oud doek, roesoe banggi genaamd, dat niet veel meer op Soemba aangetroffen wordt, een rol speelt. Dit wordt den doode als lendendoek aangelegd. Het lijk wordt met vele doeken bekleed, en een hoofddoek wordt om het hoofd gewonden, maar het gelaat blijft onbedekt. Nadat het lijk aldus is uitgerust worden de knieën opgetrokken, en om het lijf vastgemaakt; de armen gekruist, zooals dit van Kambera beschreven is. Is men hiermee gereed, dan wordt het lijk op zijn linkerzijde op een rustbank gelegd, met het aangezicht naar het Westen gekeerd. In de openingen van het hoofd wordt niets gedaan; alleen wordt een bakje met spijs er bij geplaatst: rijst, mais en lever van de geslachte dieren. Ander voedsel mag den doode niet voorgezet worden. 
In onderscheiding met de beide bovengenoemde landschappen mag in Lakoka in het sterf huis worden gekookt; de weduwe mag daar alles eten wat zij wil. Terwijl het lijk boven aarde staat, moet de weduwe in, althans bij haar woning blijven, maar na afloop van de begrafenis mag zij overal heengaan. Ook de dorpsgenooten moeten zich in acht nemen, als er een doode is. $\mathrm{Ze}$ mogen niet naar hun akkers gaan. Als reden gaf men daarvoor in Lakoka op, dat alle mannen bij elkaar moeten blijven om bij de teraardebestelling te kunnen helpen. Weven is gedurende dien tijd verboden, maar overigens bestaat er geenerlei verbod omtrent spijzen of gerucht maken. De weduwe mag hertrouwen, "wanneer de doode heelemaal in den grond verdwenen is» waarmee bedoeld wordt de tijd, waarop kan worden berekend, dat alle vleeschdeelen vergaan zijn. Men stelt hiervoor 6-8 maanden.

De lijken van vorsten en aanzienlijken worden ook wel in eigengemaakte houten kisten gedaan (een uitgehold stuk boomstam), omdat voor zulke dooden niet aanstonds de noodige beesten voorhanden zijn, die moeten geslacht worden. Het lijk wordt op de linkerzijde in zulk een kist gelegd, waarna deze dicht bij de woning in een hutje bewaard wordt. Wanneer dan na een jaar de zachte deelen vergaan zijn, wordt de kist stuk geslagen, en de beenderen worden verzameld en opnieuw in doeken gepakt. De lijken van den gewonen man gaan dadelijk in het graf, liggende op de linkerzijde met het aangezicht naar het Westen.

Het graf is een ronde kuil; op den bodem worden platte steenen gelegd, en de wanden worden eveneens met overeindstaande platte steenen bezet. Wanneer het lijk of de beenderen in dezen kuil zijn gelegd, wordt het gat met een platten steen gedekt, en daarover wordt een dolmen opgericht: een platte deksteen op vier steenen pooten. Deze deksteen wordt genoemd tanga kapoe, "de deksel van het kalkpotjes. Van de bijgebrachte goederen, voornamelijk door de zusters van den overledene en haar echtgenooten geschonken, gaat een stuk mee in het graf, terwijl de rest onder de familie wordt verdeeld. $\mathrm{Bij}$ het graf wordt ook een paard gedood, of als men zulk een dier niet heeft, een hond. Dit dier heet wala wengo, aom hem wakker te houden». De lijken van arme lieden gaan wel in een ronden kuil die met een steen gedekt wordt, maar een 
dolmen wordt er niet over opgericht; daarvoor in de plaats wordt een hoop steenen op het graf opgestapeld; op dien stapel wordt weer een half ronde steen overeind gezet.

Ook hier zijn bij de teraardebestelling van een voornaam persoon een man en een vrouw aangewezen als papangga; alleen de man heeft een bruinen haan onder den arm. Het zijn slaven (volgelingen), die bij deze gelegenheid echter \&jongere broer en zuster, van den overledene worden genoemd. In fraaie kleeding uitgedost worden zij in bewusteloozen toestand achter het lijk aan gedragen, en op het graf gelegd. Wanneer de ziel van den overledene ver weg is gegaan (de zielen van die twee kwasi bewusteloozen hebben zich dan ook ver weg begeven samen met den doode), zal het lang duren, eer die papangga weer tot zichzelven komen. Anders zijn ze weer spoedig wakker. Dan worden ze naar huis terug gedragen, waar ze hun fraaie (geleende) kleeren afleggen, en aan de familie van den overledene teruggeven. De rijken slachten den haan op het graf; armeren doen dit als ze weer thuis gekomen zijn, om daarvan tevens een doodenmaal aan te richten. $\mathrm{Na}$ afloop van de begrafenisplechtigheden blijven de papangga in denzelfden staat, als zij te voren waren.

De handen van hen die het lijk hebben begraven, worden boven het graf met water begoten. In het sterfhuis teruggekeerd, slacht men een buffel, dien men gezamenlijk opeet. Vier, vijf of zes dagen na de begrafenis wordt weer een buffel geslacht, waarmede de plechtigheden voor den doode een einde nemen. Op de dagen tusschen begrafenis en doodenfeest wordt elken dag sirih-pinang naar het graf gebracht.

Napoe en Bolobokat. Het lijk van een arm mensch wordt op den sterfdag begraven, maar dat van een rijke blijft twee of drie dagen boven aarde staan, omdat er tijd noodig is om de familieleden bij elkaar te halen en om de noodige dieren voor het doodenmaal op te vangen. Maar arm of rijk, alle lijken worden met opgetrokken knieën en gekruiste armen in doeken gewikkeld begraven. Alleen het gelaat blijft onbedekt, opdat men het nu en dan met kokoswater zal kunnen afwasschen. Alle dooden worden op de linkerzijde in het graf gelegd, met het gelaat naar het Westen gekeerd. Ook hier wordt niets op de openingen van het hoofd gelegd; alleen krijgt iemand van het maramba-(radja-) geslacht wel eens een stukje goud onder de tong ten teeken 
van zijn rijkdom; gouden en zilveren oorhangers, mamoeli, worden in het lijkkleed gestoken.

Wanneer het lijk grafwaarts gedragen wordt, geschiedt dit bij dat van een aanzienlijke in een buffelhuid, bij dat van een arme in een lap katoen, of ook wel zonder omhulling.

De radja van Bolobokat vertelde mij, dat in zijn land en in Napoe de lijken van maramba's in een steenen doodkist met deksel werden gelegd. Maar in lateren tijd is dit veranderd; nu worden de lijken op een steenachtigen bodem gelegd; er om heen worden steenen overeind gezet, en dit alles wordt weer met een platten steen toegedekt. Een poos later, wanneer alle verwanten bij elkaar zijn gekomen, en het noodige voor het doodenfeest aanwezig is, wordt het graf verder opgebouwd, dit is: er overheen wordt een dolmen opgericht. Te Pamala zag ik een reuzendolmen op zes zuilen; daaronder waren reeds vijf personen begraven. Vader en dochter, moeder en zoon, mogen niet onder hetzelfde dolmen. Onder de pas genoemde reuzendolmen was nog meer plaats; sterft iemand die in aanmerking komt om daaronder begraven te worden, dan wordt onder den steen een nieuw graf gedolven. Wanneer de dolmen wordt gebouwd, blijft het eenmaal begraven lijk rustig in het graf liggen.

Anakala. In Anakala was de oude Oemboe Dong mijn voornaamste zegsman, daarin door anderen bijgestaan. Hij vertelde mij, dat het lijk van zijn vader zeven, en dat van zijn vrouw tien dagen boven aarde had gestaan. Dit hangt af van de omstandigheid of de steenen lijkkist met dito deksel, zooals die algemeen Anakala in gebruik is, naast het dolmengraf, zooals dit van Napoe beschreven werd, gereed is. Maar aangezien meerdere lijken in hetzelfde steenen graf gaan, is het voor de teraardebestelling van meer beteekenis of de noodige dieren bijeen zijn. Wanneer daarop voorloopig geen kans is, wordt een houten kist met deksel uit een boomstam gehakt, en het lijk daarin opgeborgen. Deze kist wordt in een afzonderlijk hutje bewaard, of men zet haar in de smalle galerij, die om de huizen in Anakala loopt. Dit laatste doet men vooral met lijken van kinderen. We zagen ook zulk een kist onder een dolmen staan. Men zei dat daarin beenderen lagen van een door den vijand verslagene. Op mijn vraag, waarom men dezen doode nog niet had begraven werd geantwoord, dat er nog geen buffel voor 
hem was om hem met eere ter aarde te bestellen. Maar vermoedelijk heeft men hem nog niet begraven omdat in dezen tijd geen wraak meer voor sneuvelen kan worden genomen.

Van een doode trekt men de knieen op en kruist zijn armen, en in deze houding wordt het lijk gebonden. Zoolang het in huis is, wordt het in zittende houding op een rustbank geplaatst, maar wanneer het in de steenen of houten kist wordt gedaan, legt men het daarin op de rechterzijde neer, zoowel de lijken van mannen als die van vrouwen. Ik heb niet met zekerheid kunnen vastellen of men het lijk in een bepaalde richting legt. Van de talrijke dooden, die in het dorp zelf begraven lagen, wezen sommigen met het hoofd naar het Noorden, zoodat het gelaat naar het Westen gekeerd was. Maar het hoofdeneind van andere graven lag weer naar het Zuiden, zoodat het gelaat naar het Oosten keek. Het schijnt dat men dikwijls de lijken in de steenen urn schikt, zooals dit het best uitkomt met de beschikbare plaats. Liggen bijvoorbeeld een paar lijken daarin naast elkaar, dan wordt een derde aan hun voeteneind gelegd, dwars op de beide anderen.

Wanneer het lijk in de steenen urn is gelegd, die bijna vierkant is, en welker grootte bij de verschillende exemplaren zeer verschilt, dan heeft den volgenden dag het bonoeng tana plaats. Dit woord beteekent: aarde in iets storten, en hiermede is dus bedoeld: het vullen van het graf met aarde. Maar in werkelijkheid gebeurt dit niet. Deze naam schijnt een aanwijzing te zijn voor het feit, dat eertijds de lijken eenvoudig in den grond werden begraven. Bij dit bonoeng tan a worden voor aanzienlijken vijf buffels geslacht. Deze dieren dragen den naam van padanga, datgene wat (aan den doode) wordt meegegeven s.

Drie dagen na de begrafenis heeft weer een plechtigheid plaats, het padeta samawo, "het naar boven brengen van de ziel». Bij deze gelegenheid treedt de ratoe, de bewaker van de marapoe, op. Hij offert en bidt op den grafsteen om de ziel van den overledene tot zich te roepen. Die ziel wordt dan in de gedaante van een steentje, dat uit de omgeving van het graf af komstig is, in het sterfhuis gebracht, een gewoonte die wij op Timor algemeen toegepast vinden. In de woning wordt dit zielesteentje op een houten bord, dat als kraag om den hoofdpaal is aangebracht, gelegd. Op dit bord worden ook de offers aan de marapoe geplaatst; dit is de jarang van 
Oost-Soemba. Zoolang dit padeta samawo niet heeft plaats gehad, mogen de dorpelingen zich niet verspreiden en naar hun akkers gaan.

$\mathrm{Na}$ het opbrengen van de ziel worden geen offers meer aan den overledene gebracht. Alleen legt men nu en dan wat sirihpinang op den deksteen van het graf neer. Vooral wanneer een bloedverwant van een andere plaats komt, zal hij niet nalaten op deze wijze den doode te gedenken. Met dit doel is dikwijls een vierkant bakje in den deksteen uitgehouwen, waarin deze gaven worden verzameld.

Aan de dooden worden allerlei gouden sieraden meegegeven, vooral de reeds meergenoemde mamoeli. Die welke de doode zelf draagt, worden van het lijk afgenomen en onder de kinderen en naaste verwanten verdeeld. Dezen nemen ook het hakmes, het zwaard en de speer van den overledene; in de plaats daarvan geeft men hem andere wapenen mee in het graf. Maar zoo deden alleen zeer rijke menschen, zei Oemboe Dong mij, want vroeger waren ijzeren werktuigen en wapenen heel schaarsch op Soemba, en daarom gaf men meestal geen ijzer mee aan de dooden. De meegegeven sieraden mogen den overledene niet worden aangedaan, maar ze worden verzameld in een steenen bakje, dat bij het uitbeitelen van de steenen urn is uitgespaard. Men getuigde dat het nog nooit was gebeurd, dat een stamgenoot zich aan grafschennis had schuldig gemaakt. Mocht iemand vroeger zoo iets hebben gedaan, dan zou hij onmiddellijk zijn doodgeslagen. Maar in oorlogstijd kwam het vaak voor, dat de graven door den vijand werden beroofd. De deksels der steenen urnen werden dan eenvoudig stuk geslagen om den inhoud spoediger te kunnen bemachtigen. Er waren er zelfs die beweerden, dat juist de begeerte naar hetgeen aan de dooden was meegegeven wel eens de aanleiding is geweest, waarom twist werd gezocht, opdat daaruit een oorlog zou ontstaan, en men vrij was de graven te plunderen.

Voor de weduwe is geenerlei voedsel verboden. $\mathrm{Zij}$ mag ook buitenshuis gaan, maar zoolang het lijk van haar man boven aarde staat, moet zij er voor zorgen de sirihtasch van den doode over den schouder te hangen, wanneer zij haar woning verlaat. Ook moet zij dan een omslagdoek over de schouders slaan, iets dat de Soembaneesche vrouw anders in het dagelijksche leven nooit doet. Ook moet zij, als ze in dien tijd buiten het 
dorp gaat, niet het gewone pad gaan, maar zich verwijderen langs een weinig begaan wegje. Al deze voorschriften gelden ook voor den weduwnaar.

De gewoonte van het papangga in Midden- en Oost-Soemba kent men in Anakala ook; hier heet zij parowa, den hoofddoek omdoen»: de persoon die daarbij dienst doet heet pasapanggang ${ }^{1}$. Is de overledene een man, dan wordt hiervoor een slaaf genomen; bij een vrouw treedt een slavin als zoodanig op. Deze pasapanggang wordt keurig uitgedoscht met kleeren en sieraden van den overledene; zelfs de marangga en de lămba, twee sieraden die alleen door hooge personen, en dan nog bij bijzondere gelegenheden, gedragen worden, worden hem of haar aangedaan. De marangga is een gouden borstsieraad; de lămba is een halve maan van goud, die op het voorhoofd wordt bevestigd. Dit aankleeden van pasapanggang heeft plaats op den dag der begrafenis. Wanneer alles gereed is, valt de pasapanggang in onmacht op een van de rustbanken in de ontvangruimte der woning, en doet alsof hij gestorven is. Een haan wordt hem onder den arm geklemd, en dan nemen vier mannen hem op en dragen hem naar een ander huis. Vooraf echter wordt hij driemaal om het graf gedragen (pangadoe kaloeakoe), terwijl een versierd paard achter hem aan getrokken wordt. Dit paard wordt niet geslacht. Als de pasapanggang in het andere huis is neergelegd, wordt de doode uitgedragen.

Wanneer de pasapanggang een poos gelegen heeft, komt hij weer bij. Hij blijft voorloopig op de plaats waarheen men hem heeft gedragen, maar hij wordt van uit het sterfhuis gevoed. Eerst wanneer het padeta samawo heeft plaats gehad, keert hij naar het sterfhuis terug. De dienst, welken de slaaf op deze wijze aan den overledene heeft bewezen, wordt op geenerlei wijze beloond; hij blijft slaaf op dezelfde wijze als te voren.

Wa noekaka. In Wanoekaka wordt het lijk met water afgenomen, opdat de doode schoon bij de voorvaderen verschijnen kan; daarna wordt het met kokosolie ingewreven. De doode blijft in gestrekte houding op den rug liggen, en zoo wordt hij nadat hij is aangekleed, in geikatte doeken gepakt, niet gewikkeld. De armen gebruiken daarvoor zwart gemaakt katoen; ook wel

\footnotetext{
${ }^{1}$ pasapanggang is indentisch met papangga; voor pangga $=$ stappen, zegt men in West-Soemba, sapangga; evenals voor lakoe=gaan salakoe. 
geklopte boomschors wendt men daarvoor aan, als men niets anders heeft. Is het lijk ingepakt, dan wordt het niet gebonden. Alleen wanneer het vervoerd moet worden, wordt het met eenige banden vastgemaakt.

Het lijk gaat zonder kist in den grond, dat is een langwerpige kuil, welks wanden met platte steenen bekleed zijn. Zoowel mannen als vrouwen worden op de rechterzijde daarin gelegd, en het is daarbij geheel onverschillig naar welke richting het hoofd wijst. Het graf wordt met een platten steen toegedekt, en daarover heen richt men later een dolmen op. De groote deksteenen voor deze dolmen worden te Tarimbang vervaardigd.

Wanneer het lijk is uitgedost, wordt het naar de rustbank gebracht, waar het eenigen tijd blijft liggen; bij gewone lieden niet langer dan twee of drie dagen; bij aanzienlijken gewoonlijk vijf. Bij dit overbrengen worden een varken en een buffel geslacht. Iederen dag, zoolang het lijk boven aarde staat, moet een dier het leven laten. Bij de begrafenis worden gewoonlijk vijf beesten geslacht, waaronder ook een paard, waarop de doode komt te rijden. Om den nek van dit dier worden, voordat het wordt gedood, een menigte pakjes in kokosblad gevlochten rijst (katoepat) gehangen. Men doet dit met de bedoeling, opdat de doode, als hij in het zieleland is aangekomen, die pakjes aan zijn overleden bloedverwanten zal uitdeelen. Van het vleesch van de geslachte dieren mogen de marapoe-genooten van den overledene niet eten. Op den derden dag na de begrafenis heeft het padeta wai mata, "het naar boven brengen van de tranen» plaats, waarbij weer geofferd wordt. Een oude vrouw gaat naar het graf toe met een brandend stuk hout. Dit legt zij op het graf onder den deksteen, en teruggaande neemt ze van daar een steentje mee; dit wrijft zij met kokosolie in, en legt het dan op de leli, de boven genoemde offerplank, die om den hoofdpaal is aangebracht.

De slaaf die aan zijn heer wordt meegegeven, moet een volgeling van den doode zijn. Hij heet hier a ta papaga. Evenals in Anakala wordt hij fraai uitgedost met ringen aan de vingers; alleen de haan wordt hier gemist. Ook wordt hij, wanneer hij driemaal op de handen om het graf is heengedragen, niet naar een andere woning gebracht, maar hij keert dadelijk in het sterfhuis terug, waar hij tot op den derden dag op het slaapmatje van den overledene moet zitten. In Wanoekaka wordt 
zoo iemand, die at a papaga is geweest, wel met eenig onderscheiding behandeld. Hij blijft wel slaaf, maar wordt toch niet meer zoo overal heen gestuurd als andere slaven.

Evenals in de andere landschappen blijft ook hier de weduwe van den overledene zooveel mogelijk in huis. Alleen om hare behoeften te doen gaat zij naar buiten. $Z$ ij draagt geen weduwengewaad, of eenig teeken, waaraan men kan zien dat zij haar man verloren heeft; ook heeft zij zich aan geenerlei voorschrift omtrent voedsel te storen. Alleen mogen zij en hare kinderen niet eten van de spijs, die voor den overledene wordt klaar gemaakt, en die bestaat uit rijst met kippevleesch.

Lamboja. In Lauli en Lamboja worden de lijken weer met opgetrokken knieën en gekruiste armen gebonden, en daarna in doeken ingepakt. Het landschapshoofd van Lamboja vertelde mij met trots, dat hij voor zijn vader als deze zou komen te sterven, tien fraaie doeken uit Kodi, en drie hoofddoeken, een rooden, een gelen en een zwarten, gereed had liggen. De doeken, waarin het lijk gepakt is, worden met vijf banden gebonden: onder de voeten, over de enkels, over de knieën, over borst en armen, en boven het hoofd. Het lijk van een aanzienlijk mensch blijft van 5 tot 10 dagen boven aarde, en als het nog langer moet duren, dan makkt men wel een houten kist, waarin de doode wordt gelegd. Deze kist wordt op de rustbank geplaatst. In zulk een geval wordt echter het lijk later, als het zal worden begraven, uit de kist gehaald.

Aan den avond van den sterfdag wordt een hond doodgeslagen; het vleesch van dit dier wordt gegeten. Met welke bedoeling dit offer wordt gebracht wist men mij niet te zeggen. Herhaaldelijk worden voor den overledene dieren geslacht. Het landschapshoofd vertelde mij, dat hij voor zijn vader 18 buffels, en 3 paarden bestemd had om te worden geslacht, als deze komt te overlijden.

In Lamboja worden de dooden zoowel in steenen urnen als in met platte steenen bekleede kuilen gelegd. Over de laatste wordt dan een dolmen gebouwd. In het graf gaat van allerlei mee; mes, zwaard, lans, oorhangers en gongs. Het lijk wordt op de rechterzijde gelegd, met het aangezicht gewend naar zijn voormalige woning. $\mathrm{Zij}$ die op de $\mathrm{n}$ atara, het dorpsplein begraven liggen, hebben het aangezicht allen naar het midden van dit plein gekeerd. De steenen urn heet kabang, met welk 
woord in het Oosten de houten kist wordt aangeduid. De pilaren van de dolmen heeten ledoe, en de dekplaat sodi. Opmerkelijk is, dat in het Westen de steenen, waarmee kisten of urnen zijn toegedekt, over den rand van de kist uitsteken, zoodat ze ook den indruk maken dolmen te zijn, evenwel niet gesteund door pilaren maar door een vierkante kist.

Het gebruik van de ata papaga is in Lamboja hetzelfde als in Wanoekaka; ook hier heeft hij geen haan. Wanneer men den at a papaga driemaal om het graf heeft heen gedragen, doet men alsof men hem in het geopende graf wil werpen. Men zegt, dat hij de ziel van den overledene haalt, en met zich meebrengt in huis. Wanneer zulk een slaaf eens gedurende de drie dagen na de begrafenis stierf, zou hij met zijn heer in hetzelfde graf worden begraven. Is de overledene een vrouw, dan is de at a papaga een slavin.

Drie dagen na de begrafenis heeft ook het opbrengen van de ziel plaats, maar deze wordt niet vertegenwoordigd door een steentje.

De weduwe mag zich, zoolang pasgenoemde plechtigheid niet heeft plaats gehad, niet te ver van huis verwijderen. Ze moet drie maanden over het sterven laten heengaan, voordat ze naar een ander dorp mag gaan. Ze moet steeds den sirihtasch (Kalekoe) van haar man bij zich dragen, en heeft te zorgen dat die tasch altijd gevuld is. Zij drinkt kokos- en rijstewater, maar eerst wanneer de smart over het verlies van haar echtgenoot wat gelenigd is, zal zij weer rijst gaan eten.

Wajewa. Ook hier wordt het lijk in hurkende houding gebonden. Zoo lang het boven aarde staat, wordt het fraai aangekleed, zittende op een rustbank geplaatst; maar wanneer het zal worden begraven, wordt het in doeken gepakt, die met vier banden, als in Lewa worden vastgemaakt. Als lijkkleed mag zoowel eigen geweven als gekocht katoen worden gebruikt; alleen mag het wit zijn. Men mag er ook geklopte boomschors, zelfs een matje voor nemen. Voor dat de doode wordt ingepakt, worden alle sieraden, die hij aan het lijf heeft, afgenomen. Deze worden in de doeken gelegd, waarmee hij wordt ingepakt, zoodat hij ze toch meekrijgt. Op of in de openingen van het hoofd wordt niets gedaan.

Op den avond van den sterfdag wordt een hond geslacht; de lever wordt niet onderzocht, wat trouwens nooit met hondelevers geschiedt. Ook na de begrafenis wordt te zamen met een Dl. 78 . 
buffel een hond geslacht. Heeft men geen honden genoeg dan neemt men daarvoor ook geiten. Het vleesch van den geslachten buffel mag alleen door verwanten van den overledene worden gegeten. Van het hondenvleesch mogen broers en zusters en neven en nichten van den doode niet eten. $Z_{i j}$ zouden daarvan huiduitslag krijgen. Alleen familieleden van dezelfde generatie als de vader van den overledene mogen zich daaraan te goed doen.

Wanneer het lijk wat lang boven aarde moet blijven, bijvoorbeeld omdat de steenen kist, hier ondi genaamd, nog niet gereed is, maakt men eerst een houten kist, rongo, waarin het lijk wordt opgeborgen. Deze wordt dan in de galerij van de woning of in een daarvoor gemaakte hut geplaatst. Is men niet in staat een steenen kist voor den overledene te laten maken, dan wordt een langwerpig vierkant gat in den grond gegraven, en dit wordt met platte steenen belegd, en als het lijk er in is, met een deksteen gesloten. Zulk een steenen kamertje heet hier kabang. De bestuurder van Wajewa vertelde mij, dat er in heel dit landschap slechts één dolmen gevonden wordt, en deze stamt uit zeer ouden tijd. Sedert zijn hier geen dolmens meer opgericht.

In Wajewa wordt verschil gemaakt tusschen de lijken van mannen en die van vrouwen. De eerste worden zoowel in de tijdelijke houten kist, als in hun steenen graf op hun rechterzijde gelegd, terwijl de vrouwen op den linkerkant komen te liggen. Het gelaat van den doode is steeds naar zijn woning gericht.

Hier kent men de gewoonte van het papangga niet. Wel wordt ook hier na drie dagen de ziel van den overledene in huis gebracht, wat padeta dewana heet. Opmerking verdient dat hier het woord dewa wordt gebruikt, terwijl overigens de ziel van een overledene hier mawo heet. Die mawo noemt men een sandere, ziel, maar zij gaat toch ook in de woning van den overledene. Het padeta dewana wordt uitgevoerd door den broer van de moeder des overledenen, zijn loka. Deze gaat na het vallen van het duister naar het graf, legt daar siririhpinang neer, en roept den doode bij zijn naam. Wanneer hij meent dat de doode gekomen is, neemt hij hem mede in huis, maar ook hier wordt geen steen als belichaming van de ziel gebruikt.

De weduwe moet steeds de sirihtasch en den doek van haar 
overleden man dragen. Ze mag alles eten wat ze wil, en behalve dat zij zooveel mogelijk in of dicht bij het sterfhuis moet blijven, bestaan er voor haar geen beperkende bepalingen.

Laura. In Laura wordt in den mond van den doode wat goud gelegd, terwijl de neus, de ooren en de aars met kapok worden dichtgemaakt. Het goud zegt men, moet dienen om het lijk handelbaar te maken, zoodat het zich laat vouwen, wanneer de knieën opgetrokken, en de armen gekruist worden. Evenals overal elders komen de verwanten van den overledene te zamen om hem te beweenen, en te bewaken. Ieder gezin brengt een lap katoen voor den doode mee, en van deze geschenken wordt ondersteld, dat zij door de ziel worden meegenomen, en in het zielenland aan verwanten en vrienden van de schenkers worden uitgedeeld. Hierin sluit Laura weer aan bij de denkbeelden, die in dit opzicht bij de Timoreezen bestaan. Het lijk wordt met opgetrokken knieën in katoen of in geklopte boomschors gepakt, en met reepen van het laatste vastgebonden.

Op den morgen van de begrafenis wordt eerst een kip geslacht, die heet te dienen $\mathrm{om}$ de ziel van den doode aan den huispaal te binden», opdat zij zich niet van het sterfhuis zal verwijderen. Vlak voordat het lijk zal worden weggebracht, wordt weer een kip geslacht, en daarvan eet men samen met den doode ten afscheid. Als dit afgeloopen is, wordt de doode in zittende houding op een bamboe stellage op de schouders van eenige mannen weggedragen. Hier begraaft men ook in steenen kisten, die met een zwaren, aan alle zijden overstekenden steen gesloten worden. De lijken van mannen worden op de rechterzijde, die van vrouwen op den linkerkant gelegd. Moet de begrafenis om de eene of andere reden uitgesteld worden, dan wordt het lijk ook hier in een houten kist bewaard. Voordat het lijk in de sarkophaag gelegd wordt, worden de banden waarmee het lijkkleed om den doode gebonden is, losgesneden.

Bij deze gelegenheid wordt een buffel geslacht; van dit dier moet de broeder van de moeder des overledenen, zijn loka, den kop, het borststuk en het hart hebben, die deelen dus, welke op Timor van ieder offerdier aan de goden of geesten worden gegeven. Deze bloedverwant neemt ook het hakmes en de speer van den overledene, en wanneer deze een vrouw is, haar mes. Hier en in Wajewa zien wij dus den broer der moeder meer op den voorgrond treden. Van het paard, dat voor den 
overledene geslacht wordt, mag geen zijner bloedverwanten eten; er mag zelfs niets van het vleesch in huis worden gebracht. Van alle op dien dag gedoode dieren wordt een deel van de lever op het graf gelegd.

In den namiddag van den dag der begrafenis wordt vuur naar het graf gebracht, en dit wordt daar neergelegd. Den volgenden dag worden allerlei spijzen naar het graf gebracht, en daar achtergelaten. Een poos hierna komt de meermalen genoemde oom van den overledene, en haalt dit alles weg. alleen een weinig voor zijn dooden neef of nicht achterlatende. Drie dagen na de begrafenis wordt dan de ziel in de woning geleid door den oom, en ook hier wordt daartoe geen steentje gebruikt. Bij deze gelegenheid wordt een roode lap, die om den hoofdpaal van de woning is gebonden, toen het lijk werd uitgedragen, ten einde de ziel van den overledene daaraan te binden, losgemaakt.

$\mathrm{Bij}$ de laatst genoemde plechtigheid worden geen offers meer aan den doode gebracht. Maar in Laura wordt geen feest gevierd, geen rijst gesneden, of een deel van de offergaven en het gewas wordt aan de dooden gewijd. Wanneer bijvoorbeeld bij eenige gelegenheid enkele buffels worden geslacht, wordt een der dieren aangewezen als bestemd voor de dooden, ofschoon daarvan niets naar de graven wordt gebracht. De lever van zulk een dier wordt onderzocht om daaruit op te maken of de dooden het geschenk hebben aanvaard.

Overal waar ik op Soemba geweest ben, heb ik onderzocht, of er ook iets bekend was van het begraven in gebakken potten. Hiervan hadden de Soembaneezen nooit gehoord. Bij het wegwerken of bij ander verzet van grond was nimmer een pot voor den dag gekomen. Door den heer Wielenga, en later ook door anderen vernam $\mathrm{ik}$, dat een begrafenisplaats van aarden potten dicht bij het zeestrand bij de hoofdplaats Melolo was gevonden. De potten staan daar in drie rijen boven elkaar, en sommige bevatten nog resten van beenderen. Ik heb geen gelegenheid gehad deze plek zelf te onderzoeken, en aangezien ik dus niet uit eigen aanschouwing mededeelingen daaromtrent kan doen, laat ik dit punt voorloopig rusten.

$\mathrm{Heb}$ ik in het bovenstaande weergegeven, wat ik aangaande het begraven van lieden, die hun natuurlijken dood gestorven zijn, ben te weten gekomen, we moeten nu nog even nagaan, 
hoe men doet met de lijken van hen, die op onnatuurlijke wijze om het leven zijn gekomen. Van een begrafenis van hen, die om de eene of andere misdaad gedood werden, is natuurlijk geen sprake. Er werd een gat in den grond gegraven, en daarin werd het lijk gestopt, zooals het viel. In Oost-Soemba hield men er voor paardendieven, moordenaars, overspelers, weerwolven, en dergelijke lieden spelonken op na, waarin zulke misdadigers werden geworpen, zoodat zich op die plaatsen vele doodsbeenderen hebben opgehoopt.

Maar ook zij die door eenig ongeluk aan hun eind zijn gekomen, schijnen op Oost-Soemba beschouwd te worden als door de goden gestraften, die omdat zij zich aan iets schuldig hebben gemaakt, een onnatuurlijken dood zijn gestorven. Daarom durft men hun geen gewone begrafenis te geven. Ze worden eenvoudig onder den grond gestopt; geen dier wordt voor hen geslacht; geen sieraden of kleeren gaan mee in het graf; met het gevolg, dat de doode ook in het zielenland aankomt zonder eenige uitrusting, zoodat hij daarin niet kan worden opgenomen.

In West-Soemba schijnt men hierover anders te denken, en worden de lijken van door een ongeluk om het leven gekomenen op dezelfde wijze bezorgd als die van andere dooden. Dit is ook het geval met vrouwen, die in het kraambed zijn gestorven. De radja van Bolobokat vertelde mij, dat als een vrouw in het kraambed sterft, dit een gevolg is van een twist, dien ze met het kind, wăarvan ze zwanger ging, heeft. Daarom wordt zulk een lijk eerst "ontzondigd" (hawari), en dan wordt het op de ook voor andere dooden gebruikelijke wijze ter aarde besteld. Zelfs dood geboren kinderen, bij de meeste volken in Indië op buitengewone wijze begraven, gaan bij de Soembaneezen naar de urnen of dolmen, waarin ook hun naaste verwanten liggen te rusten.

Alleen met één soort van dooden wordt overal op Soemba een uitzondering gemaakt, en wel met de lijken dergenen, die door den vijand verslagen zijn. In Kambera brengt men het lijk van een gesneuvelden kabisoe-genoot in het dorp, waar het voor zijn woning wordt neergelegd; het mag niet in huis worden gebracht. Onder het weeklagen der verwanten wordt de doode in doeken gepakt, maar de knieën worden niet opgetrokken, hij blijft gestrekt liggen, en wordt in een langwerpig graf begraven. Op zijn laatste rustplaats, die bij de graven der andere 
menschen gelegen is, worden ook geen steenen aangebracht; alleen wordt er een stok in den grond gestoken om de plek te kunnen herkennen. Geen dieren worden voor hem geslacht. Alleen zet men wat voedsel voor hem neer, niet bij den hoofdpaal zijner woning, zooals dit gedaan wordt voor gewone dooden, maar het wordt buiten vóór zijn woning geplaatst. En wanneer op het jaarlijksche doodenfeest (waarover straks meer) aan alle overledenen voedsel wordt voorgezet, wordt op de plaats waar de verslagene rust slechts wat sirih-pinang geworpen. Alleen wanneer het den verwanten gelukt is zijn dood te wreken, en het hoofd van een vijand te veroveren, wordt de verslagene in eere hersteld. Dan worden een paard en een buffel voor hem geslacht, het eerste om op te rijden naar de Parai Marapoe of het zielenland, de tweede om hem als danga, als toerusting voor de reis te dienen. Dan ook wordt het voor hem bestemd voedsel bij den hoofdpaal in zijne woning gezet.

Ook in Napoe en Bolobokat worden gesneuvelden met gestrekt lichaam begraven, terwijl bij gewone dooden de knieën worden opgetrokken. Hetzelfde geldt voor Anakala, waar deze wijze van begraven mati palona heet. In Wanoekaka valt het niet op, dat een verslagene in gestrekte houding begraven wordt, omdat deze wijze van teraardebestellen daar algemeen is. Maar het bijzondere blijkt weer hieruit, dat het lijk niet in huis mag worden gebracht. Het wordt voor de woning op een rustbank gelegd. Daar houdt men een krijgsdans" er om heen onder het slaan op trommen en gongs. Die krijgsdans heet woletan. Voordat men het lijk grafwaarts draagt, wordt het met bloemen versierd. Een pluim van haneveeren wordt hem op 't hoofd gezet, en aan de beenen bevestigt men reepen bokkevel, waarvan het lange witte haar naar beneden valt.

In Lamboja is het weer hetzelfde: Terwijl gewone dooden met opgetrokken knieën begraven worden, blijven de lijken van verslagenen gestrekt. Men graaft een kuil voor het lijk, ergens buiten het dorp, waarbij geen windrichting in acht genomen wordt. Wanneer de doode naast den kuil gelegd is, wordt zijn rechterarm opgelicht, en de hand opengemaakt. Er worden dan zeven stukjes bladnerf van den kokospalm in gelegd, en men zegt tot den doode: "Wanneer uw hand zich spoedig om die stukjes heen sluit, zullen we uw dood gauw kunnen wreken. Gebeurt dit, dan zal het binnenkort gelukken een vijand te 
dooden. Zoodra de doode de hand sluit, heffen de omstanders den krijgskreet aan (pajauwoena). Dan wordt een matje in het graf uitgespreid, de doode wordt er op gelegd, en het graf gesloten, waarna er een hoop steenen op wordt gestapeld. Heeft men dan later het hoofd van een vijand thuis gebracht, dan slaat men daarmee eenmaal op zijn graf.

Op dezelfde wijze doet men in Wajewa met een verslagene, maar wanneer voor hem wraak is genomen, worden zijne beenderen van onder uit den steenhoop, waar ze tot dien tijd hebben gerust, te voorschijn gehaald, en overgebracht in een steenen kist, ondi. Ook in Wajewa wordt bij de begrafenis van een gesneuvelde eerst gewicheld. Daartoe wordt een pisangstam omgehouwen; wanneer daarbij uit den stomp het middelste gedeelte dadelijk opschiet, zal spoedig een vijand voor den dood van den stamgenoot moeten boeten. Ook legt men hem wel pinang in de handpalm, waarbij men op dezelfde wijze te werk gaat als in Lamboja met de stukjes bladnerf.

Wanneer we nu de boven medegedeelde gegevens samenvatten, dan zien we in de eerste plaats, dat overal op Soemba de lijken met opgetrokken knieën worden begraven, behalve in Lewa en Wanoekaka, waar het lijk gestrekt blijft. Maar ook in die streken, waar eerstgenoemde methode gevolgd wordt, wordt het lichaam in gestrekte houding gelaten, wanneer het de lijken van gesneuvelden en verslagenen geldt.

Verder worden de lijken in Kambera, Lakoka en verder in Oost-Soemba in ronde kuilen begraven, terwijl in Lewa, Napoe en Wanoekaka uitsluitend langwerpig vierkante kuilen gebruikt worden, van binnen met steenen belegd, en gewoonlijk overdekt met een dolmen. Deze met platte steenen belegde kuilen vindt men verder naar het Westen overal, maar in Anakala, Lamboja en Lauli ziet men daarnaast de steenen urn of lijkkist met een zwaren steen gedekt. Hoe meer men naar het Westen gaat, hoe meer de steenen lijkkisten overwegend en de dolmens minder worden, totdat in Wajewa met één uitzondering en in Laura uitsluitend steenen lijkkisten worden gevonden. De in den grond gegraven kuilen, die daar gevonden worden, behooren aan de armen, en zijn kenbaar aan de steenen, die er bovenop gehoopt zijn.

Wat de houding van het lijk betreft, daar waar ronde grafkuilen in gebruik zijn, wordt het in zittende houding neergelaten. 
In de andere landschappen wordt het lijk steeds op zijn rechterzijde gelegd, met uitzondering van Wajewa en Laura, waar dit alleen bij mannen geschiedt, terwijl vrouwen op de linkerzijde worden gelegd.

Menschen offer. Boven deelde ik reeds mede, dat bij den dood van een radja in Melolo een aantal slaven werden gedood. Ook vertelde men mij, dat wanneer in Lewa een vorst stierf, een gezin, dat in zijn tuin verblijf houdt, wordt aangewezen om gedood te worden. Dit geschiedde steeds in het geheim, en aangezien alle leden van zulk eene familie werden gedood, was er ook niemand, die iets van de zaak kon uitbrengen. De hoofden van deze verslagenen werden niet meegenomen; de lijken werden onder den grond gestopt.

Mijne zegslieden van Napoe en Bolobokat ontkenden, dat er bij het overlijden van een vorst ooit menschen zouden zijn geofferd. Als reden, dat zoo iets nooit heeft kunnen bestaan gaf de radja van laatstgenoemd land op: "Oorspronkelijk hebben wij in onze streek nooit slaven gehad; er waren bij ons alleen maramba (radja) en kabisoe (vrijen); hoe zouden we dus ooit iemand hebben kunnen dooden ?» 1

Van West-Soemba geloof ik te kunnen zeggen, dat daar nooit slachtoffers zijn gemaakt bij den dood van een vorst. Ik zou haast willen zeggen: Men is er daar nooit toe gekomen, want de overal bestaande gewoonte van het papangga duidt wel op denkbeelden, die nauw grenzen aan die van het menschenoffer. Het zou natuurlijk kunnen zijn, dat dit papangga een verzwakte vorm is van een vroeger bestaan hebbend menschenoffer. Een onderzoek naar de meerdere of mindere waarschijnlijkheid hiervan is hier niet op zijn plaats. Wel mogen wij aannemen, dat het menschenoffer, zooals dit tot kort voor de komst van het Gouvernement in Oost-Soemba bij den dood van radja's werd gebracht, in dien vorm is ontstaan of ontwikkeld onder invloed van de vorsten.

Wel kent men in West-Soemba het menschenoffer. Het heeft nog bestaan, toen het Gouvernement zich reeds op Soemba had laten gelden. Door den Heer Canisius er op opmerkzaam gemaakt, is het ons mogen gelukken achter deze zaak te komen.

1 In geheel Oostelijk Soemba was het gewoonte bij den dood van een vorst slaven te dooden. Hetzelfde geschiedde ook voor de voornaamste vrouwen van een vorst. Het laatste, mij bekende geval was in 1910 .

W. 
Men had haar aanvankelijk blijkbaar voor ons willen verbergen. Het verhaal, dat hier volgt werd mij gedaan door den jongen radja van Anakala.

Van tijd tot tijd werd een meisje gedood, dat af komstig moest zijn uit de afdeeling Lewata van het landschap Wajewa. Daartoe werd een meisje gekozen, dat geen familie meer had. Ze werd gedurende een jaar of zes goed gevoed en verzorgd, opdat zij onder het wachten niet zou komen te overlijden. Ze mocht zich ook niet uit de woning waarin ze verblijf hield verwijderen. Wanneer het kind tot maagd was opgegroeid, gaf de radja van Wajewa aan dien van Anakala kennis, dat «de tijd gekomen was».

Dan werden in Anakala toebereidselen gemaakt voor het groote gebeuren. Daartoe behoorde, dat twee jonge sandana(sandelhout, Soemb. ai nitoe) boomen met wortel en al uit den grond werden gegraven. De eene boom werd voor het marapoe-huis in Anakala geplant, en de andere werd in vele stukjes gehakt; deze brokjes hout werden onder alle landschappen van Midden- en West-Soemba verdeeld. Mij werden als deelhebbers aan de plechtigheid genoemd: Anakala, Wai bangga en Lauli, Wanoekaka, Lamboja, Laura, Kodi, Palamedoe, Napoe, Lakoka, Masoe en Lewa. Deze stukjes hout worden in de bronnen gelegd, opdat men gezond zal blijven, als men van dat water drinkt. De boom, die voor het marapoe-huis in den grond is gezet, is met de wortels naar boven gekeerd; men zegt, dat de geesten zich op die wortels komen neerzetten.

Was dit alles gedaan, dan stuurde Anakala een man of tien naar Lewata in Wajewa. Onderweg sloten zich bij hen nog menschen aan uit Wai bangga en Lauli. Wanneer ze bij het dorp waren gekomen, waar de maagd woonde, dan gingen de mannen op de loer liggen. Daar was men natuurlijk van alles op de hoogte. Een oude vrouw vergezelde het meisje naar het water; onderweg werd zij overvallen en afgemaakt. Haar hoofd werd afgeslagen; men nam er de scalp met het haar van af; het heele lichaam werd gevild. Behalve de huid werd ook nog de lever van het slachtoffer meegenomen.

Op de grens van Wajewa en Lauli, te Watoe mboloe, aangekomen, werden de moordenaars door lieden van Wajewa, die hen hadden achtervolgd, achterhaald. Dezen deden of ze heel boos waren, en verweten de lieden van Anakala: «Gij hebt een kind van ons gedood; wacht dus hier even; laat ons sirih-pinang 
kauwen en over de zaak praten. Dan slachtte men een buffel en een varken, die gereed gehouden waren, en kookte rijst. In de portie die voor den ratoe, den bewaker van de marapoe bestemd was, werden twee gouden oorhangers gedaan: een mamoeli loboe, d.i. een ronde oorhanger zonder uitsteeksels (beenen), en een mamoeli mapawihi, d. i. een die deze wel heeft.

Wanneer het eten gereed was, zetten allen zich aan den maaltijd. Terwijl de ratoe zijn rijst naar binnen werkte, vond hij een der twee oorhangers. Kwasi verbaasd riep hij dan uit: "Wat is dat?» Dan antwoordde de hoofdman van de Anakalaers: «Praat daar nu maar niet over, en steek het bij je.» Een poos daarna vond hij het andere sieraad. Dan riep hij weer uit: «Wat is dat?» en hij kreeg hetzelfde antwoord: "Steek het maar bij jes. Wanneer men gereed was met eten, zei de hoofdman der Wajewaers: "Laten wij nu eens over den moord spreken.» Maar Anakala antwoordde: «Wat wilt ge nog daarover spreken; we hebben immers samen gegeten, en gij hebt tweemaal een voordeeltje gehad; zwijgt dus verder over de zaak.) Dit deed men dan ook.

Scalp, huid en lever van de maagd werden naar Wai bangga gebracht; de eerste twee werden daar gedroogd; vele menschen stroomden er te zamen, en dan werden de drie genoemde deelen van het lichaam van het vermoorde meisje onder de reeds genoemde landschappen verdeeld. In Analaka werd het stukje huid onder het trommelvel van een lage trom, deri genaamd, geplakt; de andere landschappen plakten het lapje menschenhuid onder het vel van de Lamba marapoe, een bijzonder groote trom, die bij plechtige gelegenheden voor de stamgoden wordt geslagen. Het haar werd bevestigd aan de twee pilaren, die de nok van het marapoe-huis steunen. Het stukje lever eindelijk dat aan iederen stam werd toebedeeld, werd in een bamboegeleding gedaan, en boven in het marapoe-huis bewaard. Wanneer een groot marapoe-feest werd gevierd, werd op de porties rijst voor de oude mannen bestemd met een stokje wat van de lever uit den bamboe gelegd. Dit werd echter alleen in schijn gedaan, want bij het lepelen uit den bamboe werd gezorgd, dat niets van den inhoud meekwam. Daarna werd de koker weer gesloten en opgeborgen. In Anakala werden de porties rijst, waarop wat van de menschenlever was gelegd, niet gegeten, maar in den 
grond begraven. Wanneer de lever in het vat vergaan was, begon men er over te denken om weer een meisje te dooden.

Tijdens het leven van den vader van Oemboe Dong had men dit voor de laatste maal gedaan, en in hun naïveteit hadden de menschen kort voor mijn komst op Soemba aan den Bestuurder verlof gevraagd om deze "plechtigheid» weer te mogen volvoeren. Welke de oorsprong van de heele handeling is, wist men niet te zeggen.

Nog bij andere gelegenheden kwamen in dit deel van het eiland menschenoffers voor. Deze staan in verband met slangendienst. Bij Wai bangga (Lauli) is een grot, waar een groote slang heet te wonen. Dit dier is een marapoe, een godheid. De lieden van Lauli en Wai bangga gaan daar ieder jaar heen, en brengen er offers van rijst en kippevleesch. Van Lauli is het slechts een deel dat aan deze plechtigheid meedoet, namelijk de lieden van Lauli boven, want die zijn van Wai bangga afkomstig. Die van Lauli beneden zijn van Anakala gekomen. Men offert in deze grot, opdat er genoeg regen zal vallen, en de bronnen voldoende water zullen opleveren om de sawahs te bevloeien. Alles wat daar gevraagd wordt, zou men ook krijgen.

Een geheel enkele maal werd bij deze grot ook een maagd gedood, waarvoor een onderhoorige werd bestemd. De tolk, dien ik te Lauli had, een Soembanees van een jaar of dertig, vertelde, dat hij dit eens had bijgewoond, toen hij nog een kleine jongen was. Het offer was toen een meisje dat men in Wanoekaka had gekocht. Zij werd met een touw om den nek gewurgd, en daarna in de grot geworpen. Aan deze gewoonte ligt het volgende verhaal ten grondslag: Een arme man ontmoette eens twee pythons, die met elkaar aan het vechten waren. Toen de man aankwam, hielden de dieren op met vechten, en een hunner zeide tot hem: "Nu gij vrede tusschen ons hebt gemaakt, zal ik u beloonen: ik zal u dertig buffels en een stuk sawahgrond geven, maar dan moet gij ons nu en dan een maagd offeren.»

Ditzelfde verhaal moet volgens den Heer Canisius in Anakala bestaan. Daar waren het twee broers, van wie de oudste de heele erfenis, en de jongste niets kreeg. In de wildernis ronddwalende, ontmoette hij twee vechtende slangen, die hij van elkaar scheidde, waarop een harer hem rijk maakte, onder voorwaarde, dat uit elke generatie zijner nakomelingen een maagd 
aan de slang zou worden geofferd. Deze werd daartoe in een groot gat in de aarde gestort.

In Wajewa wordt verteld, dat in den ouden tijd een menschenpaar twee zoons ter wereld bracht. De eene heette Oemboe Bobo Pola Kawatar (pola=stengel; watar=mais); deze was met een staart geboren en ontwikkelde zich weldra tot een python, kaboko. De andere zoon heette Oemboe Ramba Namo; deze was een gewoon mensch. Hij trok naar Lamboja, waar hij de stamvader werd van de menschen die dat landschap bewonen. Oemboe Bobo heet nog steeds te wonen in een grot bij het stamdorp Tanggeba (in Wajewa). Volgens het verhaal heeft die grot zeven deuren, maar daar binnen is het zoo licht alsof de zon er schijnt. Er zijn paarden, buffels en gongs, maar voor menschenoogen is dit alles onzichtbaar. Vroeger ging men geregeld eens in het jaar eten aan de slang brengen, maar nu had men dit in geruimen tijd niet meer gedaan, zei men. Vroeger zou men bij deze gelegenheid de deuren van de grot hebben geopend, en als Oemboe Bobo en zijn nakomelingen dan naar buiten kwamen, gaf men aan elk van hen een bordje met rijst. Maar wanneer zich onder de offeraars een dief bevond, greep de slang hem aan, en liet hem niet los, voordat hij zijn kwaad had bekend. Daarom durfde men later de dieren niet meer naar buiten laten komen. Men deed de deur op een kier open, en wierp het voedsel naar binnen om de opening weer gauw te sluiten.

In Wajewa ziet men in den python een voorvader, en als men zulk een dier ontmoet, spreekt men het aan met Oemboe, heer of grootvader, en men werpt het wat sirih-pinang toe. Alleen wanneer een python kippen steelt, doodt men hem. Het lichaam wordt begraven, en men legt er een stukje katoen bij. Op het graf legt men steenen.

In Laura is een hol bij de kampong Leko, die Kaleboe Ende heet. Daar wonen pythons, aan welke men eens om de twee of drie jaar, wanneer men aan ze herinnerd wordt, eten gaat geven. Vooral de lieden van de kampong Kadonggan bij de vestiging Karoeni gaan daar offeren. Een buffel, een varken, een geit of ook wel hoenders worden daar geslacht. Bij de spelonk is een katoda, een overeindstaande steen waarop de offerande wordt gelegd, en een stok waaraan de kaken van de geofferde dieren worden opgehangen. 
Deze vereering staat in geenerlei verband met den landbouw. De aanleiding daartoe is een besmettelijke ziekte geweest, die in het land heerschte. Toen had iemand de meening geopperd, dat dit onheil wel eens door de slangen, die in die grot wonen, kon zijn veroorzaakt, en daaruit was de vereering van die dieren voortgekomen.

$\mathrm{Er}$ is nog een kleine bont gekleurde slang, die evenals de python kaboko wordt genoemd. Deze wordt in Wajewa, Laura en Kodi beschouwd als de zoon van een grooten marapoe, geest. De python wordt in Laura toegesproken met 'vader, of 'grootvader, en men werpt hem sirih-pinang toe als men hem ziet. Alleen als hij steelt, wordt hij gedood. Het lichaam wordt dan in een boom opgehangen, opdat de honden het niet zullen eten. Met moet een doode slang nooit begraven, zegt men in Memboro, want dan zal ze weer herleven. Men werpt sirih-pinang naar het doode dier en verontschuldigt zich, dat men haar heeft gedood met de woorden: "Het is niet onze schuld, want ge hebt gestolen».

In Lakoka vertelde men, dat het daar is voorgekomen, dat iemand van een groote slang droomde, die tot hem zeide: *Daar en daar moet gij een steen, katoda, voor mij oprichten, dan zal ik u veel herten en varkens bezorgen». En toen de man gedaan had, wat de slang hem had gezegd, werd hij een gelukkig jager.

Toen een van de sterkste rotsvestingen in Midden-Soemba, Paraing Madita, "de hooge stad", werd gebouwd, vond men daar heel veel slangen. De hoofdman van deze dieren veranderde zich in een mensch, en gelastte den Soembaneezen een huis voor hem te bouwen, en een rooden buffel te slachten. Toen men zulk een dier niet kon vinden, stelde de geest van die plek zich te vreden met een varken en een geit, en hij gaf voorschriften omtrent eenige woorden, die daar niet genoemd mochten worden. Toen de woning voor den slang-geest gereed was, en de gevraagde offers gegeven waren, verdwenen de slangen en deden den menschen geen overlast aan. Toen de menschen van Masoe (Taboendoeng) eens deze vesting te vergeefs hadden bestormd en weer waren afgetrokken, werden zij, in het bosch gekomen, door de slangen overvallen; deze vernietigden de menschen, zoodat geen enkele hunner naar huis terugkeerde (Macedoniër XII, 1908, bl. 42-44). 
De macht, die aan den python wordt toegeschreven, blijkt ook uit een verhaal, dat de Heer Wielenga in Kapoendoek vernam. Daar beviel een vrouw van zulk een dier. De slang werd naar een grot gebracht, maar zij keerde naar de woning terug. Dit herhaalde zich eenige malen. Toen beraadslaagde de familie er over om het dier te dooden, maar de slang was van dit plan op de hoogte, en zij waarschuwde de menschen: "Doodt mij niet, want dan zou er een groote watervloed komen, en de aarde zou in stukken breken. "Dan zullen we je in zee werpen ", zeiden de menschen. "Dat is goed", antwoordde de slang, want daar zal ik genoeg te eten hebben». Men deed haar in een vaartuig, en roeide haar een heel eind in zee. Toen wierp men haar over boord. Maar een paar dagen daarna stierf de moeder, die de slang had voortgebracht, en het duurde niet lang, of zij die het dier naar zee hadden geroeid, werden ernstig ziek en de een na den ander overleed.

In Maka menggit (Lewa) vertelt men, dat wanneer iemand zonder aanleiding een python doodde, alle andere slangen met hem zouden komen vechten, en hem zouden dooden. Voor den inwoner van Kambera is de python een ratoe maramba, priester vorst. Wanneer men zulk een dier ontmoet, werpt men het een goudschilfertje toe en men zegt: "Gij gaat hierheen, en ik ga daarheen». Dan zal de slang stilhouden en men gaat haar voorbij. Heeft een python gestolen, dan slaat men hem dood, en men begraaft hem in den grond, maar niet dan nadat men hem een goudschilfertje in den bek heeft gelegd, en haar heeft toegesproken: "Gij hebt uw eigen dood uitgelokt, en daarom zijt ge gestorven .1

Het spreekt van zelf, dat bij deze vereering van den python zijn vleesch ook niet gegeten mag worden. Hierop maken enkele streken op Soemba een uitzondering, en wel Tana maringi en Ende, beide dicht bij Wajewa gelegen. Hier merkt men niets van slangenvereering; de menschen maken zelfs met honden jacht op pythons, en eten hun vleesch. Dit wordt gekookt, maar het mag niet in den kampong worden gebracht, evenmin als de vaten, waarin het vleesch gekookt, en die waaruit het gegeten is. Het is niet verboden om het vleesch te roosteren, maar men zegt, dat het dan dadelijk vlam zou vatten, en dat deze zoo hoog

$1 \mathrm{Ik}$ heb in Kambera ook wel gezien, dat de doode python in een boom werd gehangen.

W. 
oplaait, dat alles in den omtrek verbrand zou worden. De Evangelist Wadoe vertelde mij, dat toen hij eens in Tana maringi werkte, een vrouw door een python werd gedood; het dier had zich om haar lichaam gekronkeld en haar verstikt. De menschen doodden het dier, maar in dit geval mocht het vleesch niet gegeten worden. Ook in Tana Rara bij Laura is het aan een deel der bevolking verboden slangenvleesch te eten, aan een ander deel niet.

Voor andere slangen heeft men geen eerbied. De zwarte slang, kabota genaamd, slaat men in Kambera altijd dood, als men haar ziet; men zegt dat dit dier een slaaf is, die komt stelen. Wanneer men een gewone slang uit een graf ziet kruipen, moet men trachten haar te dooden, want dit is een dief, die het goudwerk, dat zich bij den doode bevindt, is gaan stelen. Komt een slang in huis, dan slaat men haar dood, want ze is de ziel van een slecht persoon, die den boel komt opnemen. Adders, kataroe moeroe, worden overal op Soemba gedood.

Wat hier van Kambera is gezegd, geldt ook voor de andere landschappen. Sommigen jagen slangen alleen weg, zoolang ze nog geen verkeerde dingen hebben gedaan. In Lakoka vertelde men nog, dat als een slang in een huis komt, dit een bewijs is, dat in die woning overspel of bloedschande is gepleegd. De zaak wordt dan met "het meten van de speer » nader onderzocht. Ook de beteekenissen die men aan de ontmoeting met een slang hecht, zijn overal dezelfde. Zulk een ontmoeting, hetzij dan dat het dier den weg kruist, voor den persoon uitgaat of dezen te gemoet komt, voorspelt altijd iets slechts, en men keert daarom naar huis terug. Moet men noodig voort, dan snijdt men in sommige streken wel een stukje van een zijner kleedingstukken af (liefst van een dat van geklopte boomschors gemaakt is), werpt dit naar het dier toe, en gaat dan door.

Met het vel van den python worden wel trommen bespannen, maar dit zijn dan uitsluitend kleine trommen, kataboe, die bij den marapoe-dienst worden gebruikt.

De $\mathrm{Ziel}$. $\mathrm{Na}$ de uitweiding over slangenvereering, waartoe wij door het menschenoffer zijn gebracht, keeren wij terug tot de dooden, om te zien wat de Soembanees zich denkt van het leven der ziel. Voor ziel heeft men op Soemba twee namen. De inheemsche luidt: hamangoe (Kambera, Wanoekaka), hamaoe (Napoe), samawo (Anakala), mao (Lamboja). De 
andere naam voor ziel die van vreemden oorsprong is, luidt: ndewa in Oost-Soemba, dewa in West-Soemba. De inheemsche ziel gaat in de woning en verblijft daar boven den haard. In Wanoekaka drukte men dit aldus uit: De hamangoe gaat met de ata papaga mee, dit zijn zooals we weten, de slaven die in bewusteloozen toestand om het graf worden gedragen, maar ten slotte weer in de woning teruggebracht worden. De dewa daarentegen gaan op reis naar het zielenland. Uit de bijzonderheden, die daarover beneden zullen volgen, zal duidelijk blijken, dat wij met twee verschillende voorstellingen hebben te doen, die soms naast elkaar staan, soms ook ondereen vermengd zijn. ${ }^{1}$

Voor den Soembanees in het Oosten bestaan twee zielensteden. De eene is gelegen op kaap Sasar, de andere in het bergland van Masoe. De stammen die hun afkomst afleiden van Oemboe Waloe Sasar laten de zielen hunner afgestorvenen naar eerstgenoemde plaats gaan. De nakomelingen van Oemboe Waloe Mandokoe gaan naar Masoe. De gedachte aan een zielenland dat onder de aarde gelegen zou zijn, is nog niet geheel verdwenen. In Karera toch wees men den Heer Wielenga in een bosch een grooten steen aan, waarvan men zeide, dat hij den toegang tot de onderwereld bedekte. Het gelukte den Heer Wielenga met zijne tochtgenooten den steen af te wentelen, en ofschoon er niets te ontdekken viel, durfde geen der Soembaneezen dicht bij die plek te komen. - Verder heeft ieder landschap nog zijn locaal zielenverblijf, waar de afgestorvenen eerst heengaan, om dan een poos later de reis voort te zetten. Opmerkelijk is het verhaal van de omzwervingen der ziel, dat men men mij in Wajewa deed, waarbij de ziel achtereenvolgens enkele parai marapoe, doodensteden, bezoekt. In elk daarvan

1 In Kambera maakt men dit onderscheid tusschen ndewa en hamangoe. Ndewa is meer het algemeen levensbeginsel. Zoo hebben menschen, dieren en planten een ndewa. Van die ndewa zegt men: hama toena na ngiloe na ndewa na: gelijk de wind is zijn ziel. En zoo ook: na ndewa na na tau mameti na he ja la awang: de ziel van den overledene stijgt naar den hemel.

En in de tweede plaats beteekent het: een geest: bv. ndewa paraing de kamponggeest; ndewa pakariang, iemands geleidegeest.

Ha mangoe wordt meer gebruikt in den zin van bewustzịn. en is alleen in het bezit van den mensch. Zoo zegt men van iemand die van schrik flauw valt: $n a$ hawoeroeng na hamangoe na, zijn ziel is weg gevlogen.

W. 
sterft de ziel weer om na haar dood de reis voort te zetten. Uit deze omstandigheid blijkt ook, dat verschillende cultuurinvloeden op de Soembaneezen hebben ingewerkt. Uit de ervaringen, die een volk de ziel zijner dooden laat maken, zijn veelal aanwijzingen te vinden voor zijne geschiedenis.

Zooals boven gezegd is, ligt de doodenstad, parai of paraing marapoe voor een deel der menschen van Oost-Soemba in een bosch op het gebergte van Masoe. Hoe het er daar precies uitziet, weet men niet te zeggen. Uit de verhalen, die op dit zielenland betrekking hebben, blijkt wel, dat alles wat er leelijk uitziet daar het ware is, een trek dien men bij de beschrijving van het zielenland van nagenoeg alle volken in Indië vindt. In het verhaal van de Tooverkip bijvoorbeeld (Macedoniër XIII, 1908, bl. 306-311) wordt de aardbewoner, die een bezoek aan de doodenstad gaat brengen, door zijne geleiders gewaarschuwd om geen sirih te nemen uit een mooi pas gevlochten mandje, maar uit een kopgeraapt van den grond, een beschimmeld mandje». - Op het terrein, waar men zich de doodenstad denkt, loopt een kudde paarden rond, die voor ieder heilig zijn, want dit zijn de geesten-paarden, de rijdieren der afgestorvenen. Alleen wanneer men vijanden het hoofd heeft afgeslagen, mochten deze tropeeën op een marapoe-paard geladen, en zoo vervoerd worden. Alleen voor dit doel mochten ze worden opgevangen, en na gebruik werden ze weer losgelaten (alleen merries werden daartoe gebezigd). Dat deze troep dieren niet grooter is, wordt door den Soembanees daaruit verklaard, dat de voet van een regenboog onder de kudde heeft gestaan, wat het fatale gevolg voor de kudde dieren heeft, dat er dan vele beesten van sterven. (Ook wanneer de voet van een regenboog op een akker heeft gerust, meent men dat op dien grond niets meer groeien kan; men neemt niet eens de moeite het te beproeven. Als men er met den vinger naar wijst zal deze verdorren).

In Napoe en Bolobokat heeft ieder distrikt zijn zielenland, parai marapoe (Napoe), katomoe (Bolbokat), maar ten slotte verzamelen zich toch alle zielen op Sasar. Als ze daar aangekomen zijn, worden ze door den deurwachter tegengehouden. Deze heet Oemboe Kababa. Dan komt de heer van het zielenland kijken of de nieuw aangekomene van de familie is, en of hij geenerlei "zaak» heeft, waarmee op Soemba altijd bedoeld is, of hij op sexueel gebied niet iets ongeoorloofds heeft gedaan. Dl. 78. 
Is dit inderdaad het geval, dan moet de ziel eerst "ontzondigd" (h a w a ri) worden, voordat zij kan worden toegelaten. Men woont daar in huizen door den grooten voorvader gebouwd, en men eet daar droge rijst, die er uitziet als aarde.

De ziel, dewa, gaat naar het Westen; daar steekt zij een droge rivierbedding over, die Binawatoe heet. Daarna gaat zij achtereenvolgens de rivieren van Wajewa, Lamboja, Wanoekaka, Tarimbang, Tidas, Rindi (Rende), Kadomboel, Mananga bokoel (Kambera), Kanatang, Kapoendoek en Kadasang over. Na deze wandeling, die het grootste gedeelte van het eiland omvat, komt de ziel in de parai marapoe op Sasar aan (Opmerkelijk is, dat de ziel Laura en Kodi niet aandoet). De ziel trekt over al die rivieren, gezeten op het paard, dat voor hem is geslacht, en hij wordt bij dat overtrekken geholpen door den "eigenaar van het water». De zielestad bestaat uit een groot zwaar bosch. Wanneer de ziel daar is aangekomen, moet ze eerst wachten, tot de eerste voorouders bij haar zijn gekomen. Dit voorouderenpaar is Bokoe Dangi met zijn vrouw Apoe Lawa. Later, in Lauli, hoorde ik het verhaal omtrent deze twee menschen. Ze werden daar Dangi en Lau genoemd. Vroeger, vertelde men, was Soemba door water bedekt; alleen het pas genoemde paar woonde ergens op de watervlakte. Ze plantten wilde postelein, roeta rewa, en een boom, dangi rara genaamd. Om dien boom verzamelde zich hoe langer hoe meer aarde. Toen kregen die twee menschen kinderen. Dezen huwden met elkaar en kregen weer kinderen, en zoo vermenigvuldigden zij zich in grooten getale. Zij verdeelden zich in kabisoe's en landschappen. Een van deze nakomelingen was Oemboe Seboe. Deze was van Soemba weggegaan door de steenen brug, die van Sasar af over de zee voerde, over te gaan. Toen hij na geruimen tijd nog niet teruggekomen was, werd iemand afgevaardigd om hem te gaan zoeken. Deze afgezant droeg den naam van Koeala. $\mathrm{Na}$ een lange wandeling over de steenen brug, kwam hij aan de overzijde van de zee, en daar vond hij Oemboe Seboe te midden van prachtige rijstakkers, waarop hij rijst had geplant, die hij van Soemba had meegenomen. Oemboe Seboe had ook veel kinderen en kleinkinderen. Koeala kwam met de tijding, dat Oemboe Seboe niet naar Soemba wilde terugkeeren, en hij vertelde van al de heerlijkheid die hij aan de overzijde van de zee gezien had. Toen kwam de lust in het hart van vele Soem- 
baneezen op om ook daarheen te gaan. Daarover werden de hoofden ongerust. Ze beraadslaagden met elkaar, en kwamen tot het besluit: "Laten wij de steenen brug afbreken, want anders gaan al onze onderdanen daarover naar Oemboe Seboe». Maar ze waren niet in staat de brug stuk te maken, en daarom vroegen ze hulp aan de bliksem (kabala). Deze liet toen de brug springen, en sedert werd de gemeenschap met het land aan de overzijde der zee verbroken. Toch bestaat die brug in de voorstelling der menschen nog, want de lieden van Napoe, in wier land Sasar ligt, vertellen ook, dat de zielen in de parai marapoe weer sterven, en dan gaan zij naar "de groote stad,, die Leti nggaba tana wola heet, "het land van onzen oorsprong", zei men. Dit land ligt aan de overzijde der zee, en de weg die er heen voert is een steenen brug.

Maar keeren wij tot Bokoe Dangi en Apoe Lawa terug. Deze twee komen naar de doodenziel toe, en vragen haar of haar api wâla [vonk] is gegeven. Daaronder verstaat men de buffels en andere dieren, die voor den overledene worden geslacht. Ook andere vragen doen zij nog aan de ziel: Hebt ge een rijpaard? Hebt ge den inhoud van den mond (het stukje goud dat onder de tong wordt gelegd)? Wat voor kleeren en goederen brengt ge zooal mee? Wanneer de ziel op al deze vragen voldoende geantwoord heeft, mag zij binnengaan. In dit zielenland moet ook een groot raadhuis wezen, dat op steenen palen rust; daarin wonen de voorvaderen. Alle voedingsmiddelen, die men gewend is op aarde te eten, worden ook in de parai marapoe genuttigd.

Wanoekaka, Lauli en Lamboja zijn de landschappen, waar de ziel niet naar Sasar gaat. $Z_{\mathrm{ij}}$ blijft in de doodenstad, die zich in die streken zelf bevindt. In eerstgenoemd landschap is deze op een berg, die dicht bij de grens van Anakala ligt. Toja kara loedoel kaboeang noemt men deze plek. Daar planten de dooden pisang en suikerriet, waarvan ze leven. Van een bewaker en een hoofdman in dit doodenrijk wist men niets. In Lauli gaat de ziel eerst naar het Oosten en vandaar naar Wai bangga, van welke plaats een deel der Lauliërs afkomstig zijn. Daar in de buurt zijn drie plaatsen waar de zielen bij elkaar komen. Ze heeten Pora nemboe wala woeasoe; Kabata teko kaneki lodi; en Randa lima jela kadakoe lima mbani. Ook op deze plekken planten de schimmen pisang en suikerriet.

In Lamboja worden ook de schaduw en het spiegelbeeld van 
den mensch met hetzelfde woord mao aangeduid, als de ziel. Men onderscheidt de $\mathrm{mao}^{1}$ van het water of spiegelbeeld, dat na den dood van den mensch in het water gaat, en de mao van de zon, de schaduw, die later naar de zon verhuist. De eigenlijke ziel of $\mathrm{mao}$ gaat naar de doodenstad, de parona mati mema. Deze ligt aan de monding van de Lambojarivier. Het zeestrand op die plaats draagt den naam van Sasar malaingoe, kataka lindi watoe. Van een zielenland bij Kaap Sasar wisten de lieden van Lamboja niets, maar in den naam van de plek, waar hun doodenstad is, vinden wij den naam Sasar terug. De Heer Wielenga vertelde mij, dat op een oude kaart van Soemba een kaap, die zich aan de Zuidkust in Wadjeloe bevindt, ook kaap Sasar wordt genoemd.

Het verhaal, dat men mij in Wajewa deed met betrekking tot het zielenland is wel merkwaardig. Het locale zielenland is hier een bosch bij Tanggeba, waar de menschen uit deze streek eertijds bij elkaar hebben gewoond. Daar planten de dooden oeli, colocasia, en wi'a, Alocasia macrorhira, waarvan de wortel gegeten wordt (Mal. birah). Daarom is in Wajewa een uitdrukking voor sterven: "Hij is Colocasia gaan planten». In deze doodenstad is geen hoofdman, en er heeft geen onderzoek van de zielen plaats. Maar nadat de ziel er een poosje is geweest, sterft ze, en dan gaat de nieuwe ziel naar Bondo terepa, dat is het landschap Lamboja. Vervolgens gaat ze naar Roea, en dan naar Parai Wetana (Pamala). (Ze slaat dus Wanoekaka over.) In laatstgenoemde plaats sterft ze nog eens, en dan trekt ze verder naar Lewa, en ten slotte naar Sasar. Voordat ze daar binnen kan komen, moet ze een groote rivier over. De rijken doen dit te paard, maar de armen moeten daartoe een brug overgaan, die uit een boomstam bestaat. Deze brug schudt hevig. Er onder loeren vele krokodillen in den stroom. Ze wachten met geopenden bek op de eene of andere ziel, die van de brug zal vallen. Dit gebeurt met ieder, die niet volgens de adat begraven is. Onmiddellijk wordt zij dan door een der krokodillen opgeslikt en ze komt niet in de parai marapoe.

Onder degenen, die ook een prooi dezer dieren worden, behooren vrouwen, die de vrucht hebben afgedreven, en $z \mathrm{ij}$, wier kind levenloos ter wereld is gekomen. De afgedreven vrucht

In Kambera beteekent ma oe, schaduw, schaduwbeeld. 
en het doodgeboren kind bevinden zich onder de brug en trekken de moeder daarvan af, zeggende: "Gij hebt ons het leven niet gegund, en daarom zult ge niet in het zielenland komen.» Door de onvoldragen vrucht te verwijderen, is de vrouw in een onreinen (taboe-) toestand gekomen, die haar verhindert in de doodenstad te komen. Daarom het ontzondigen, en de uitdrukking, dat de moeder met haar doodgeboren kind twist heeft gehad.

De zielen van rijke lieden, ata pote, drijven de beesten, die bij hunne begrafenis geslacht zijn, met veel geschreeuw over de rivier; daardoor worden de krokodillen bang, en gaan op zij. Op deze wijze komen de rijken ongehinderd over de rivier.

In Sasar gaat de ziel nog eens dood, en dan verhuist zij naar den hemel. Daar sterft ze voor het laatst en dan wrijft Ine Kalada-Ama Kalada haar tusschen de handen fijn. Het stof strooit ze over de aarde, en overal waar dit neerkomt, wordt het groente, rijst, mais, paarden en buffels. Wanneer de bloedverwanten goed voor de begrafenis hebben gezorgd, komt het stof van den overledene bij hen neer, en dan worden ze rijk. Wanneer dan een vrouw uit zulk eene familie van de gewassen of van het vleesch der dieren eet, die uit het neergevallen stof van den overledene zijn ontstaan, dan wordt ze zwanger en zal een kind baren. Op deze wijze komt de overledene weer op aarde terug. Dat dit denkbeeld algemeen op Soemba bestaat, kan ook blijken uit de gewoonte om aan kinderen namen te geven van overleden grootouders en hunne broers en zusters.

In Laura, waarvan de inwoners uit Wajewa afkomstig zijn, heeft men hetzelfde verhaal. De inheemsche ziel blijft echter op de lele la mbe, de plank om den hoofdpaal in huis (deze hoofdpaal heet in Laura koko pongga). Er zijn er ook die zeggen, dat de ziel of naar Tanggeba of naar Sasar gaat.

Op één trek in de voorstellingen omtrent het zielenland moet nog gewezen, en wel op het al of niet aanwezig zijn van honden aldaar. In het Westen weet men daar niet van, evenmin als men daar iets weet van een onderzoek, dat de ziel moet ondergaan. Maar in het Oosten vinden we den hemelhond overal, en gewoonlijk in verband met "vergelding". In Kambera wordt in een verhaal aan een bezoeker van de doodenstad door zijne geleiders geraden: "Als wij straks bij de deur komen, treedt dan goed in onze sporen, want er zijn veel kwaadaardige honden». 
Omtrent de honden in het Hiernamaals lezen we in een ander verhaal. Er is een hond, die zoo groot is als een palmboom, en die Kaboata heet (zoo worden ook de pythons genoemd ${ }^{1}$ ), (Macedoniër XIII, 1908, bl. 308 en 328). In Napoe vertelt men, dat een hond den toegang tot de doodenstad bewaakt. Deze draagt den naam van Djalikoe Tawongoe, lembar amba lata (tawongoe=wesp; lembar=over den drempel heenstappen).

In Anakala vernam ik, dat aan de poort der doodenstad een groote hond zit, wiens naam overeenkomst heeft met dien welke hem in Napoe gegeven wordt: Kombakoe lebadi lebar tawongoe. Dit zou dan de naam zijn van het mannetje, want er is ook een wijfje, dat Kobokoe marapoe heet (kobokoe is de bladscheede van de pinang). Volgens anderen weer heeten die twee honden: Galakoe en Leberi. Wanneer nu de overledene, wiens ziel te Sasar aankomt, tijdens zijn leven ongeoorloofde huwelijksgemeenschap heeft uitgeoefend (bloedschande heeft bedreven), of gestolen heeft, dan blijt die hond zijne ziel, duwt haar op zij, en jaagt haar van Parai marapoe weg naar het "veld; dit in tegenstelling met het bosch waar de doodenstad is. Op het "veld moet de ziel op die van een anderen doode wachten om dan samen met deze het zielenland binnen te gaan. Bedoeld zal wel zijn, dat de ziel moet wachten tot degeen met wie zij bloedschande heeft gepleegd, of degene, van wie ze het eigendom ontvreemd heeft, overleden is, om dan te zamen met hem of haar hun zaak te doen beslechten door den hemelschen rechter.

Hebben wij boven gezien, dat men in sommige landschappen de ziel van hen, die door een ongeluk om het leven zijn gekomen, niet naar de doodenstad laat gaan in andere streken weer wel, omtrent één soort van dooden zijn alle Soembaneezen het eens, dat hun ziel daar niet komt, namelijk van hen, die gesneuveld, door den vijand gedood zijn. Overal, zoowel in West- als in Oost-Soemba laat men die zielen rechtstreeks naar den hemel (het uitspansel, awang) gaan, waar zij sterren worden. De radja van Bolobokat vertelde mij er nog bij: "Als een vorst sneuvelt, wordt zijn ziel een kleine ster; die van een kabisoe

1 Dit is zeker wel de oorspronkelijke beteekenis van kaboata, want dit woord bevat het bestanddeel ata, vgl. Fidji ng at a, "slang”, Bis. a ta „dierlijk gif", Paaelohi (Ceram) mananate, ngifslang", Bare'e doeata, Mota-sch mata. (Adriani). 
(edelman) of ondergeschikte is grooter. Daarom zegt men, dat als een ster dicht bij de maan staat, er spoedig iemand door de hand van den vijand zal vallen. Maar wij gaan niet graag naar den hemel toe; hij is zoo ver weg, en wij weten niet hoe het daar uitziet; in de Parai marapoe is het veel gezelliger; daar zijn allen bij elkaar».

De zielen der afgestorvenen blijven steeds invloed oefenen op het leven der nagelaten bloedverwanten. Ze worden daarom in alle omstandigheden van het leven aangeroepen, en in huis worden offers aan hen gebracht, in Oost-Soemba op de jarang bij de deur, in West-Soemba op de leli om den hoofdpaal der woning. Maar dit geldt dan de meer intieme, de inheemsche ziel. Met de zielen van Parai marapoe komt men ook in aanraking, maar dit zijn dan "zielen» in het algemeen, niet zoozeer de zielen van bloedverwanten. Het zijn de doodenzielen van de folklore, wanneer wij hooren van de ontmoetingen der menschen met hen. Wanneer men verdwaalt op plaatsen waar men meent, dat die schimmen zich ophouden, moet men oppassen. Meestal is men in zoo'n geval verloren, omdat men te laat bemerkt, met dooden te doen te hebben. Vooral moet men er voor waken geen voedsel tot zich te nemen, dat in de doodenstad wordt aangeboden, want in dat geval zal men onherroepelijk moeten sterven. Aan enkele dingen kan men zien met zielen van afgestorvenen te doen te hebben. Zoo zien hun dorpen er nieuw en fraai uit en er is een overvloed van voedsel.

In alle landschappen heeft men een soort van "allerzielen", op welk feest alle afgestorvenen worden herdacht. In Oost-Soemba wordt dit feest ieder jaar gevierd. Dan worden de dooden in het dorp bijeen geroepen, en wanneer ondersteld wordt dat allen bijeen zijn, worden dieren geslacht om hun te eten te geven. Dit feest, langoe paraing geheeten, wordt gedacht als een verzoeningsfeest tusschen levenden en dooden: de eersten hebben de laatsten wel eens vergeten; de dooden hebben nagelaten verwanten wel eens gestraft met ziekte en ongeluk. Maar nu zal het alles weer vrede en rust zijn. Allen groot en klein, voornaam en gering, dragen tot dit feest bij. $\mathrm{Na}$ afloop er van worden de dooden weer weggeleid. Ieder huis maakt dan voor zijne dooden een kokosdop met asch gereed, waarin drie kippeveeren zijn gestoken. Die dop wordt buiten de voorpoort van den kampong neergezet. De asch zegt men zal maken dat de dooden ge- 
makkelijk terug kunnen loopen, want asch blijft altijd droog, en ze behoeven zich dan niet aan den steenachtigen bodem te stooten. De veeren heeten te zijn om schaduw te geven onderweg, opdat zij zonder sterke zonnehitte naar hun verblijf kunnen terugkeeren. Naar dit gebruik wordt de Parai marapoe of zielenstad in het dagelijksche leven wel kaba a'oe, "kokosdop met asch * genoemd (Verg. Macedoniër XII, 1908, bl. 299-300).

In Wajewa heet dit zielenfeest $1 \mathrm{i}$ ' ma rapoe. Het wordt om de zeven jaar gevierd. Dan komen alle lieden van dit landschap te Tanggeba bijeen. Ook de menschen van Laura, die uit Wajewa afkomstig zijn, waren gewend er heen te gaan, maar sedert geruimen tijd zijn zij er niet meer geweest, want sedert de grootvader van mijn zegsman (en deze was zeker iemand van 50 jaar) het feest had meegemaakt, was men er nooit meer heen gegaan. Voor drie jaar zijn die van Laura nog eens door de lieden van Wajewa uitgenoodigd, maar aan die uitnoodiging heeft niemand gehoor gegeven, Vroeger was men gewend om bij het begin van het feest de menschen die van Laura kwamen, te gemoet te gaan; had men elkaar gevonden, dan trok men den volgenden dag gezamenlijk naar Tanggeba. Op dit feest wordt katoepat gegeten, dat zijn pakjes rijst, die in gevlochten kokosbladeren zijn gekookt. Deze pakjes zijn te voren in groote hoeveelheid gereed gemaakt. Wajewa en Laura waren gewend deze pakjes rijst met elkaar te ruilen, zoodat ze elkaars rijst aten. Daarbij werden buffels, varkens, geiten en kippen geslacht; paarden en honden niet. Een speciaal offer aan de dooden wordt niet gebracht, maar men legt iets van het eten voor hen terzijde en men roept de dooden op om aan den algemeenen maaltijd deel te nemen. De onderkaken der varkens en de horens der buffels, die bij deze gelegenheid geslacht zijn, worden aan de boomen van het bosch opgehangen.

Koppensnellen. Toen wij over de gewoonten bij de begrafenis in gebruik spraken, hebben we gezien, dat men in het Oosten gewend was om bij gelegenheid van den dood van een radja eenige menschen te slachten, maar dat men er op uit ging om menschenhoofden te halen, kwam niet voor. Of men wel eens een menschenhoofd ging halen bij gelegenheid van de oprichting van een marapoe-huis of vorstelijke woning? Men had den Heer Wielenga verteld, dat dit vroeger wel in Napoe gebeurde, maar toen wij nader onderzoek hiernaar deden, werd 
het ontkend (wat niet wil zeggen, dat zoo iets inderdaad nimmer is voorgekomen). Overal waar ik naar deze aangelegenheid vroeg, ontkende men, dat zulk een gewoonte vroeger zou hebben bestaan, maar de Savoeneesche Evangelist Wadoe vertelde mij, dat toen hij eens een poos lang in Kodi moest verblijven, men hem had verteld, dat daar bij de oprichting van het marapoehuis te Lete nggaro een mensch was geslacht.

Van het ontstaan der gewoonte om de hoofden der verslagen vijanden weg te nemen, wist men mij nergens eenige overlevering te vertellen. In Laura werd mij verteld, dat de lieden daar de hoofden namen van de inwoners van het landschapje Tana rioe, met wie men in erfvijandschap leefde. Tusschen die twee streken kon nooit sprake van vrede zijn. Wanneer die van Laura in oorlog waren met Wajewa, Kodi of Memboro (verder strekten de vijandelijkheden zich niet uit), en er werd iemand neergelegd, dan werd wederzijds nooit het hoofd van den gevallene meegenomen. Zulk een veete als die tusschen Laura en Tana rioe, bestond ook tusschen Lewa en Taboendoeng; tusschen Lamboja en Wanoekaka. Wanneer iemand uit een der laatstgenoemde landschappen een bloedverwant in het andere wilde opzoeken, moest hij dit in de stilte des nachts doen, anders liep hij veel kans om zijn hoofd kwijt te raken. Nergens wist men mij de reden voor zulke veeten op te geven.

Of het koppensnellen nog in verband staat met den landbouw? Een zeker bewijs heb ik daarvan in Lewa gekregen, waar men mij vertelde, dat nu en dan aan de gesnelde koppen te eten werd gegeven, omdat ze anders boos zouden worden, en dan zou men geen goeden oogst krijgen. Van uit Lewa zou men ook in Taboendoeng gaan snellen, opdat de aanplant goed zou gedijen. De beide a ndoeng-palen, waarover beneden meer, worden ook wel eens genoemd: andoeng watar (= mais), en andoeng oehoe (= rijst). Ook in Laura schijnt er verband te bestaan tusschen koppensnellen en landbouw. Beneden zullen wij daarover iets vinden wat het landschap Taboendoeng betreft.

Natuurlijk konden allerlei kwesties aanleiding geven tot een oorlog, gepaard met koppensnellen. De oorlogstoestand tusschen twee streken, die in voortdurende veete met elkaar leefden, leek onzekerder en onrustiger dan hij in werkelijkheid was, want men bepaalde er zich toe wraak te nemen voor een verslagene. Was iemand gevallen, dan konden diens stamgenooten er zeker 
van zijn, dat ze vooreerst met rust gelaten zouden worden, en dat het nu aan hen was om er op uit te gaan om den dood van den verslagene'te wreken. Zoo kende iedere partij tijden van betrekkelijke rust en veiligheid.

In het Oosten was de aanvoerder van den troep strijders de moni mbani, «de dappere». Vaak was dit bij de groote ondernemingen de radja zelf, maar gewoonlijk gaf deze de leiding over aan een edelman, kabisoe, zelfs wel aan een slaaf-onderhoorige. Voordat men uittrok, werden overal op Soemba de geesten aangeroepen en een varken en hoenders geslacht, welker levers nauwkeurig werden onderzocht, om te weten, wat den strijder te wachten stond; waren de teekenen ongunstig, dan werd de tocht uitgesteld. Schrikte men onderweg een wild varken op, dan moest men dit zoo lang achtervolgen tot men het had neergelegd, want als dit niet gelukte, zou men geen geluk hebben, en daarom keerde men dan ook in zoo'n geval terug. Kwam een varken den troep achterop, dan zou men zeker een vijand neerleggen, maar wanneer het den weg overstak, dien de strijders gingen, dan zouden ze geen geluk hebben, waarom zij dan ook omkeerden. Boven hebben we gezien, dat de ontmoeting met een slang al even ongunstig is. Moest het paard, waarop de aanvoerder gezeten was, onderweg urineeren, of hoorde men een aap schreeuwen, dan was het ook geraden om terug te keeren.

Onder de vogels op welke bij een krijgstocht gelet werd, bekleedde de kraai (nggangga, gaga of nggaka) een eerste plaats. De strijders toch gingen op roof uit, om zich een menschenhoofd te verschaffen; en onder de vogels zijn de kraaien de roovers. Zag men op zij van den weg kraaien en begonnen ze te krassen, dan juichten ze de mannen toe en voorspelden hun geluk op hunne onderneming. Dan wierp men den vogels wat sirih-pinang toe, en vervolgde goedsmoeds zijn weg. Maar bleven de vogels stil op hunne plaats zitten zonder eenig geluid te geven, dan bleek daaruit, dat de strijders zich niet op een goeden uitslag zouden kunnen verheugen, en daarom keerden zij maar liever weer naar huis terug. Dit was gebiedend noodig, wanneer een kraai den weg kruiste, want daarmee wilde hij den mannen den pas afsnijden, omdat zij voortgaande gewonden en dooden zouden krijgen. (Dit geloofde men ook van den kiekendief, ikitoe, ikoetoe, wikita, die over den weg vloog.) Werd de 
troep door een schaar kraaien (of door een kiekendief) achtervolgd, dan mocht men op een voorspoedigen tocht rekenen. Komt een kraai of een rawa (een groote groene duif met grijzen kop, Mal. pěrgam) 's nachts in het dorp roepen, dan moet men op zijn hoede zijn, want dan heeft de vijand een overval in den zin. Komt overdag een troep kraaien leven maken bij een huis, dan zal de eigenaar van de woning spoedig sterven.

Behalve dit algemeen op Soemba bestaande geloof in de bewegingen der kraaien, houdt ieder landschap er nog zijn eigen overtuigingen op na met betrekking tot de vogels. Zoo zal men in Lauli, wanneer daar 's nachts een wetja, een vogel die in de sawah leeft, bij de omheining van het dorp komt schreeuwen, iedereen wakker maken, want dan moet men op zijn hoede zijn, omdat de vijand komt. Dit geldt ook voor de keila, het rijstdiefje.

Wanneer de houtduif, mbara, in Oost-Soemba 's avonds of 's morgens vroeg koert, wat zij gewoonlijk niet doet, dan gaat men den volgenden dag niet op weg, want dan zou men verliezen lijden. Of ook voorzegt dit geluid, dat er dieven met hun handwerk bezig zijn. Wanneer een kiekendief 's nachts schreeuwt, waarschuwt hij voor hetzelfde gevaar.

De uil die nu eens naar zijn geluid koeoe (kooe, kowo) wordt genoemd, dan weer met zijn werkelijken naam wângi (wane) wordt aangeduid, speelt in oorlogstijden geen rol. Wanneer men op het oorlogspad zijnde een uil hoorde schreeuwen, ging men onder den eenen of anderen boom sirih-pinang offeren, opdat het kwaad, dat dezen vogel en vooral zijn geluid, aankleeft, de mannen niet zou volgen. Voordat de kampong Lambanapoe in 1901 verwoest werd, vertelt men, zwierven een maand van te voren groote vluchten van deze vogels in de nabijheid van het dorp rond. De uil wordt gehouden voor de verpersoonlijking van de heks, den weerwolf, mamaroe, of mamaroeng (zie over den weerwolf Macedoniër XIV, 1910, bl. 235-242). $\mathrm{Hij}$ is de vogel van ziekte en dood. Wanneer hij zich 'snachts in het Kamberasche laat hooren, legt men een kind dat op zijn rug ligt te slapen, gauw op zijn zij om, totdat het geluid weggestorven is. Men mag ook over dat geluid geenerlei opmerking maken, of een teeken van verwondering geven, want dan zou men moeten sterven. Wanneer dan ook kort nadat het uilengekras gehoord is, iemand sterft, zegt men wel: «Hij heeft zeker op het geluid geantwoord. Wanneer deze vogel zich op 
een papaja-boom neerzet, gelooft men dat de boom dood zal gaan. Gaat hij op den nok van een huis zitten, waarin zich een zwaar zieke bevindt, dan zal deze moeten sterven. Is er niemand ziek, dan tracht men door wichelen met de lans te weten te komen, wat voor kwaad het dier (de heks) hier komt doen. Hoort men een uil krassen in Lauli (en waarschijnlijk is dit ook in andere landstreken het geval), dan werpt men asch naar buiten. Het geschreeuw van een uil kan ook beteekenen dat er dieven in de buurt zijn.

Terwijl haar man ten strijde is getrokken, moet de vrouw zich voor verschillende dingen in acht nemen. Alleen van Anakala heb ik deze gewoonte nauwkeurig genoteerd. Hier moet de vrouw onder meer doen alsof zij weduwe ware. $\mathrm{Zij}$ moet zooveel mogelijk thuis blijven. Als het noodig is, dat zij den kampong voor een korte poos verlaat, moet zij dit niet langs den hoofdweg doen, maar zij volge daartoe een van de kleine paadjes, die op verschillende punten uit den op een hoogte gelegen kampong naar beneden leiden. Verder doet zij water in een houten bak, en plaatst die op de lili ai, de reeds meer genoemde offerplank, die om den hoofdpaal is vastgemaakt. Dit moet dienen, opdat haar man "koud" blijve, dat het hem goed blijve gaan. Is hij van de tocht teruggekeerd, dan wordt dit water zonder meer weggeworpen. De vrouw mag gedurende de afwezigheid van haar man het hoofdhaar niet losmaken. Ze moet zorgen dat het vuur niet uitgaat; van dit vuur mag zij aan niemand buitenshuis afgeven. Ook andere dingen mag ze niet aan menschen van een ander huis leenen. Ze mag niet naaien, niet vlechten, niet weven; liefst moet zij maar stil blijven zitten.

Het eenige verschil in de gebruiken die gevolgd worden, wanneer men met een hoofd is teruggekeerd, is, dat in sommige landschappen het hoofd versch in het dorp wordt gebracht, terwijl in andere streken hiermede gewacht wordt tot het is geprepareerd. Zoo bijvoorbeeld in Kambera. Daar legt men het hoofd in een gat tusschen de steenen, en bewaakt het. De wakers worden vanuit den kampong geregeld van eten voorzien, maar zij zelven mogen niet naar binnen gaan. Alle vleeschdeelen worden van het hoofd verwijderd en in een gat begraven, dat bovendien nog met steenen wordt overdekt, opdat de honden den afval niet zullen opgraven. Dan wordt een vuur aangemaakt, 
en daarboven wordt het hoofd gedroogd. Intusschen zijn buffels en varkens bijeengebracht, die zullen worden geslacht, wanneer de tropee naar binnen zal worden gedragen. Op den afgesproken dag staat de ratoe, de bewaker van den marapoe, de strijders bij den ingang van het dorp op te wachten. Hij gooit een ei op den grond stuk, en strooit er gestampte rijst over; daarover loopen de mannen, ten einde door deze middelen het kwade dat zij met zich medebrengen, te niet te doen. In het dorp wordt het hoofd op een staak, andoeng gezet, dan danst men er om heen en viert feest, waarbij de noodige dieren worden geslacht.

In Lewa Pakoe ging het nagenoeg op dezelfde wijze toe. Een bepaald persoon (waarschijnlijk iemand die dit werk gewoon is te doen) ontdoet het veroverde hoofd van de zachte deelen; ook de hersens worden uit den schedel gepeuterd. Onder dit schoonmaken staan de andere krijgers er om te springen en ze voeren spiegelgevechten uit, waarbij zij telkens den oorlogskreet gillen; nu en dan roepen ze: Nggoekoe nggela, *de bewegelijke nek». Aan het vuur waarop het hoofd gerookt wordt, roosteren de mannen brokken varkensvleesch voor zich, waarvan zij zeggen: «Wij eten menschenvleesch». Op een zijner reizen vroeg de Heer Wielenga eens aan den radja van Napoe om een gids naar Anakala; maar de vorst zeide, dat hij aan dit verzoek niet kon voldoen, omdat «de menschen daar menschenvleesch aten»; hij bedoelde: in oorlog waren.

Degeen die na het verslaan van den vijand het hoofd van den romp scheidt, moet daarbij oppassen dat het bloed van den gevallene hem bij dit werk niet bespat, anders zou hij nooit meer geluk hebben. Zoo iemand zegt overdrachtelijk: «Ik heb menschenvleesch gegeten *.

$\mathrm{Bij}$ het binnengaan van het dorp worden de mannen op dezelfde wijze ontsmet, als dit in Kambera geschiedde. Degeen, die het hoofd heeft schoongemaakt, brengt het ook in den kampong, en plaatst het op den staak. Het overwinningsfeest begint dadelijk na terugkeer der strijders. Iederen nacht wordt er dan gedanst, waarbij door mannen en door vrouwen, ieder op verschillende wijze wordt gegild; van de mannen heet dit $\mathrm{kajâka}$, van de vrouwen kakâlakoe. Het dansen, dat daarbij wordt gedaan, heet rendja. Wanneer de kop aan den staak wordt opgehangen, wordt een buffel geslacht en dan heeft een groote maaltijd 
plaats. Na afloop hiervan wordt de rendja-dans niet meer uitgevoerd; het feest is afgeloopen. Valt het hoofd van den stok, dan worden de resten buiten den kampong begraven.

De lieden van Lakoka wrijven het veroverde hoofd met asch in en doen er dan mee, zooals we pas van Kambera en Lewa hebben vernomen. Alleen met dit verschil, dat de afgesneden vleeschdeelen in een aarden pot worden gekookt, te zamen met wat varkensvleesch. Daarna wordt alles met pot en al in den grond begraven. Om die plek wordt een krijgsdans uitgevoerd, s a r a m a genaamd.

Wanneer men in Napoe en Bolobokat na den gelukkigen terugkeer der strijders twee dagen feest heeft gevierd en gedanst (heroe), wordt het nog ongeprepareerde hoofd onder veel geschreeuw en lawaai in het dorp gebracht. Voor het marapoe-huis is een stapel bamboelatten gelegd en daarop wordt het hoofd geplaatst. Na een poos wordt het er weer afgenomen en aan een draagstok gebonden, waarop twee mannen het onder een oorverdoovend gebrul en gegil van de aanwezigen driemaal om het marapoe-huis (ook wel andoeng-huis genoemd) dragen. Op het punt waar men de ommegangen aanvangt, staat een groep vrouwen, elk met een bakje asch gewapend. Iederen keer dat het hoofd voorbij haar gedragen wordt, strooien zij wat van de asch er op. Is het hoofd zoo driemaal rondgedragen, dan wordt het weer op den hoop bamboe gelegd. Daarna worden buffels geslacht en viert men het feest. Na afloop hiervan wordt het hoofd begraven. Men laat het 2 à 3 maanden in den grond, waarna het weer wordt opgegraven, schoongemaakt en aan den staak in het dorp opgehangen. Bij die gelegenheid heeft het groote feest plaats; daarbij worden trommen en gongs duchtig geroerd. Bij deze gelegenheid wordt het hoofd niet meer om het marapoe-huis heengedragen.

Als in Anakala bericht ontvangen was, dat de uitgetrokkenen in aantocht waren, ging de ratoe hen te gemoet. Deze waardigheidsbekleeder trok nooit mee uit ten strijde, maar gedurende de afwezigheid van de mannen bad hij tot de marapoe, en slachtte nu en dan eens een hoen voor hen. Het buitgemaakte hoofd mocht niet dadelijk in den kampong gebracht worden, maar het werd gedurende drie dagen aan de dorpspoort opgehangen. De helden mochten ook nog niet binnen gaan, maar dit belette niet, dat de overige dorpsbewoners iederen nacht dansten en 
feestvierden. Intusschen nam de $\mathrm{r}$ a t o e het hoofd onder handen: hij sneed de haren af; daarvan werd een pakje gemaakt en dit werd opgedragen aan marapoe Manoe. Van dezen geest ben ik niet meer te weten gekomen, dan dat hij vereerd wordt in een huis, dat staat in den kampong Karoe Beba, het eerste van het complex gehuchten, dat op een heuvelrug gebouwd is, en dat te zamen Anakala vormt. De vleeschdeelen, die van het hoofd werden gesneden, werden begraven. Was de kop geprepareerd, dan werd hij door den ratoe binnen het dorp gebracht; deze hield daarbij het hoofd op zijn beide handen voor zich uit. Bij den ingang van het dorp drukte de ratoe een op den grond gelegd ei met den grooten en den tweeden teen stuk, terwijl de strijders allen met gestampte rijst werden bestrooid. Ook stond daar iemand met een bakje met asch gereed, waarmee hij de oogen en de kin van den kop inwreef, indien deze aan een gewoon dorpeling had toebehoord. Was het 't hoofd van een edelman, dan werd het alleen met wat asch bestrooid, want op zulk een hoofd zou de opgesmeerde stof niet blijven kleven, zegt men. De intocht had plaats onder een ontzettend gejoel en geraas van gongs en trommen, die voortdurend werden geslagen. Zoodra de stoet binnen was, werden een buffel, een varken en een hoen geslacht. Daarna trok de stoet driemaal om de huizen, die aan het dorpsplein (n âta ra) zijn gebouwd, en ten slotte werd de kop aan den staak opgehangen, waarbij weer een buffel het leven liet. Het behoeft nauwelijks gezegd te worden, dat bij deze gelegenheid een schitterend feest werd gevierd.

In Lamboja ging het bij het terugkomen van een troep, die een hoofd van den vijand gekregen had, heel wat eenvoudiger en ook ruwer toe. Zoodra bericht ontvangen was, dat de gelukkige strijders in aantocht waren, trok men hen vanuit het dorp met gong en trommelslag te gemoet. De mannen werden dadelijk den kampong binnen geleid, zonder eenige ontsmettingsceremonie te ondergaan. Eerst 's avonds, wanneer het feest was, werden de strijders met gestampte rijst bestrooid. Door een gat in de wang van den kop was een stuk rotan of liaan gestoken en vastgemaakt en daaraan werd het hoofd over den grond voortgetrokken. Was men erg verbitterd, dan hield men dit soms een geheelen dag vol. Ten slotte bracht men het hoofd weer naar buiten, en hing het aan een boom op. Soms zette 
men het voorttrekken van den kop nog een paar dagen, voort. Had men er genoeg van, dan werd het hoofd gekookt, totdat de vleeschdeelen er gemakkelijk van verwijderd konden worden. Die afgekookte deelen werden begraven. Het hoofdhaar dat te te voren werd afgesneden, werd verdeeld tusschen hem, die den vijand verslagen had, en de twee mannen, die clen kop hadden rondgedragen. Het schoongemaakte hoofd werd aan den andoengstaak opgehangen, waarbij weer een groot feest gegeven werd.

Daar in Wanoekaka een koppensnellerstroep meestal uittrok op verzoek van den een of ander, die den dood van een bloedverwant wilde wreken, wanneer deze door Lauli of door Lamboja gedood was, bleef zulk een troep als hij teruggekomen was, voor het dorp wachten, totdat de lastgevers hem met een buffel en een varken te gemoet kwamen. Dan werd met het buitgemaakte hoofd gedaan als pas van Lamboja verteld is; bij den ingang van het dorp stond de ratoe, die aan de mannen de vraag deed: "Wie zijt gij?» Dan luidde het antwoord: "Wij zijn een hoofd gaan stelen, en wij komen nu van den tocht terug». Dan werden zij met gestampte rijst bestrooid en een ei werd stuk geslagen. In optocht trok men vervolgens door den kampong, waarbij vrouwen den kop aan een lijn die door de wang liep achter zich voorttrokken. Het behoeft niet gezegd, dat dit met een groot lawaai en geschreeuw gepaard ging, terwijl voortdurend op trommen en gongs geslagen werd. Het hoofd werd voor de marapoe-woning schoongemaakt; de afval werd buiten den kampong begraven; van het hoofdhaar werd een deel in een pakje gedaan en dit werd bewaard in de woning van dengeen die door de Lambojaers gedood was, voor welken persoon men wraak was gaan nemen. Wanneer het hoofd daarna op den staak werd gezet, had hierbij weer een groot feest plaats.

Nagenoeg op dezelfde wijze ging men in Wajewa te werk. Bij het binnenbrengen van den kop werd Ina Kalada-Ama Kalada, mawolo mawari ("maken, scheppen») aangeroepen. Want deze is het die den menschen bevolen heeft geregeld te gaan snellen. Men geeft hem dus kennis van de gelukkig geslaagde onderneming. Hij wordt aangeroepen bij den marapoe katodang, den steen die op het dorpsplein, nâtara, staat; op dien steen werd sirih-pinang gelegd, maar overigens geen offergaven van rijst of vleesch. Bij het betreden van het dorpsplein trapten allen op sirih-pinang en een ei om zich te ontsmetten. Het 
haar van den kop werd afgesneden, en deze werd bij den steen begraven, totdat berekend kon worden, dat alle zachte deelen vergaan waren. Dan werd het hoofd weer opgegraven en op een staak gezet, die van een bijzondere bamboesoort gemaakt was, wo'o geheeten. Deze bamboe met het hoofd er op werd aan de andoeng gebonden. Dit ging met een groot feest gepaard. Het hoofdhaar van den verslagene werd aan de marapoespeer gebonden, de lans van den voorvader, die als medium en krachtvoorwerp wordt bewaard.

Over Laura kan ik kort wezen, omdat de gebruiken bij het koppensnellen hier dezelfde waren als in Wajewa. De rato bara, "spreekrato", of rato marapoe, de ratoe die voor de geesten zorgt, ging de strijders te gemoet, en deed hun eenige vragen: "Hoe is het, hebt gij geluk gehad?» "Wie is gedood? Wie heeft hem verslagen?» De mannen werden ook met rijst bestrooid en een ei werd stuk geworpen.

Reeds eenige malen is het woord andoeng genoemd. Dit zijn in Oost-Soemba twee houten staken, die voor het marapoehuis zijn opgericht. Bij de oprichting wordt alleen een goudschilfertje in een propje katoen gewikkeld, onder den staak gelegd. Om den voet van deze palen is een hoop steenen opgestapeld, ongeveer 2 M. lang, 1 M. breed, en 0.75 M. hoog. De staak die naar het Zuiden staat is van boven gevorkt of uitgebeiteld, alsof het een paal ware voor huisbouw bestemd, om er een balk op te leggen. Dit is de mannelijke andoeng. De vrouwelijke, die naar het Noorden staat, is recht. We zouden juist verwachten dat de eerste de vrouwelijke en de tweede de mannelijke was, en ik ben geneigd te gelooven, dat men dit ook zoo heeft bedoeld, vooral omdat aan den laatstgenoemden paal de veroverde koppen werden opgehangen. In Anakala staan de beide palen een eind van elkaar af, de vrouwelijke is met een hekje omringd en er is een bamboestaak met takken bij geplant om er de hoofden aan op te hangen.

In het Westen heet de andoeng: katoda, en daar gebruikt men er maar één. In Laura zijn het twee steenen, katoda bei en katoda mane, vrouwelijke en mannelijke katoda. Daarbij is een bamboestaak opgericht, waaraan de koppen worden opgehangen. In het Westen staat deze $\mathrm{kat}$ o d a voor veroverde menschenhoofden steeds buiten de $\mathrm{n}$ ata $\mathrm{ra}$, het dorpsplein.

Men vindt deze andoeng (O.S.), of katoda (W. S.) alleen Dl. 78. 
in de stamdorpen. In de later gemaakte kampongs mogen ze niet wezen. De radja van Lewa bijvoorbeeld, komt van Lewa Pakoe, maar hij was eensdeels door erfrecht, anderdeels door verovering ook heer van Kambera geworden. Daarom had hij zijn hoofdzetel in de buurt van Kawangoe. Hier had hij een namaak-andoeng opgericht: een stok met kokosdoppen er aan. Als zijne mannen dan een kop hadden gekregen, werd het koppensnellersfeest eerst in zijn nieuwe woonplaats gehouden en daarna werd het hoofd naar het stamdorp Lewa Pakoe gebracht, $60 \mathrm{KM}$. daar vandaan.

De andoeng moest steeds van een bepaalde soort hout zijn. In Lewa was de mannelijke andoeng van ai kapehoe, in Lakoka van kapiesoe, in Napoe van kapesoe. Maar de vrouwelijke andoeng in deze drie landschappen moest van koendjoer-hout zijn. Deze laatste is de houtsoort die voor dit doel het meest aangewend wordt. Zoo ook in Lamboja, waar deze boom modjora, en in Wanoekaka, waar hij moedjoer heet. De koendjoer is een boom, die lange peulen als vruchten draagt, waarin harde, platte zwarte vruchten van de grootte van een gulden, waarmee door Savoeneezen gespeeld wordt. Voor gewone huizen mag dit hout niet worden aangewend; alleen mag het gebruikt worden voor marapoe-huizen, woningen, waarin de stamgoden wonen. In Anakala is de mannelijke andoeng van bangi-hout, dat ook gebruikt wordt voor palen van gewone huizen. De vrouwelijke andoeng is daar van manini-hout.

Wanneer de andoeng vergaan of verbrand is, zooals in 1901 met die van Lewa Pakoe gebeurde, wordt weer een nieuwe opgericht. Dit geschiedt als er weer eens een kop is buitgemaakt. Deze vernieuwing verhoogde dan nog de luisterrijkheid van het feest. Het is de ratoe, die de nieuwe andoeng plaatst. In Lewa werden de mannen bij zulk een gelegenheid met *honden, toegesproken. De vorsten heetten dan "groote honden", het volk "kleine honden». Van het vleesch van den geslachten buffel werd aan ieder zijn aandeel toegeworpen, zooals men dit aan honden pleegt te doen. De bedoeling is duidelijk: de mannen werden geacht honden te $\mathrm{zijn}$, die bij een voorkomende gelegenheid dapper zullen aanvallen.

In Laura staat nog een derde paal midden op de natara (dorpsplein). Deze draagt den naam van pangande deta, "die het naar boven meeneemt. Deze paal is van petoe- of 
van kêtoka-hout gemaakt; kêtoka is weer de koendjoer van Oost-Soemba. Ieder jaar wordt daar een feest gevierd, waarvan de tijd ook niet is voorgeschreven. Dit feest heet wôleka $\mathrm{na}$ $\mathrm{k}$ atoda. Het wordt niet tot afwending van eenige ziekte gehouden, maar het heeft alleen ten doel om rijk te worden en den oogst te doen gelukken. Ook in Lewa (en waarschijnlijk in nog andere landschappen) wordt ieder jaar een feest gevierd om de andoeng, opdat de regens zullen doorkomen en het gewas zal gedijen. De ratoe's komen daar ook allen te zamen. De radja van Lewa weet het aan het verwaarloozen van deze gewoonte, dat in den laatsten tijd zoo weinig regen viel en de oogst nogal eens mislukte.

In het Westen laat men de hoofden op de andoeng hangen, tot ze vergaan zijn en vervangt ze door steenen. In het Oosten blijven ze op den staak, tot de vrede gesloten is met het land vanwaar de hoofden genomen zijn. Dan worden die tropeeën afgenomen en begraven. Vrede sluiten heet pata kandjora, "de lansen verbreken». Ik heb boven reeds medegedeeld, dat sommige landschappen in zoodanige veete met elkaar leefden, dat er tusschen hen nimmer sprake kon zijn van vrede. Maar de meeste oorlogjes waren van tijdelijken aard. Als een der partijen vrede wenschte te sluiten, werd een invloedrijk man uit een onzijdig landschap aangezocht om de zaak in orde te brengen. Daartoe bracht de vredemaker een doek naar de tegenpartij, en bepraatte haar om haar tot den vrede te bewegen. Was zij daartoe bereid, dan gaf zij aan den tusschenpersoon sirih-pinang en een of meer oorhangers, mamoeli, mee, als bewijs van hare goede gezindheid. Daarna volgden meerdere samensprekingen.

In het Oosten gaf de overwinnaar bij het vredesluiten aan den overwonnene een slavinnetje, dat den naam droeg van hiloe na na mamohoe na mamili, "de vervangster van het verrotte en afgedrevene». Als tegengeschenk voor dat meisje gaf de andere partij allerlei gouden voorwerpen. Met het meisje deed men verder niets bijzonders; zij werd uitgehuwelijkt aan een der huisslaven. $\mathrm{Na}$ het uitwisselen dezer geschenken werd de omgang tusschen de beide landschappen weer vriendschappelijk.

$\mathrm{Hu}$ isbouw. De kern van een Soembaneesch huis is de stookplaats, die in Oost-Soemba algemeen a oe, "asch» heet; meer naar het Westen karaboekoe, raboeka, raboeko. Deze 
plek ligt tusschen de vier hoofdpalen van' de woning, en aangezien die palen in een vierkant staan, is ook de haard steeds een vierkant. Behalve de stookplaats is ook de oema deta tusschen deze vier palen aangebracht. Dit is een zoldering onder de nok. Hierop worden de heilige voorwerpen bewaard en hier wonen de geesten der voorvaderen, de $\mathrm{m}$ arapoe en de later gestorvenen, zooals wij in het begin van deze mededeelingen reeds hebben opgemerkt. Vrouwen mogen daarheen niet opklimmen, en van de mannen alleen zij, die tot het huisgezin behooren. Boven zijn de vier palen met dwarsbalken verbonden, en daarop rusten weer twee stijlen, die de nok dragen.

De vier hoofdpalen, de kambaniroe (O.S.) kabaringoe (W.S.), pari'i (W.S.) zijn dus de deelen van de woning die het eerst worden opgericht. Van die palen is die in den NoordOost hoek de voornaamste. Hij wordt dan ook het eerst geplant, dan die in het NW., verder die van het ZW., en eindelijk die van het ZO. De voornaamste paal heet in O.S. kambaniroe oeratoeng; oeratoeng beteekent het nagaan van de lijnen bij de lever der geslachte dieren, om daaruit te zien of een offer is aangenomen, of men geluk op zijn onderneming zal hebben; ook wordt met oeratoeng wel eens wichelen in het algemeen aangeduid. In Napoe legt men behalve een goudschilfer, nog wat buffelfaeces en een kippenei onder den paal. De faeces dienen om het huis koel, gezond te maken. In Anakala wordt bij de oprichting van den hoofdpaal een hond geslacht en daarna een buffel. Behalve de goudschilfer, legt men onder den hoofdpaal nog mos uit de beek; dit moet speciaal dienen om moeders, die kleine kinderen hebben koel te maken, opdat zij altijd voldoende melk voor haar zuigelingen zullen hebben. In Lamboja gaat er een stukje van een gouden oorhanger en wat sirih-pinang onder; in Wajewa en Laura alleen een goudschilfer. Dit gebruik is dus over geheel Soemba vrijwel hetzelfde. Ook het brengen van een offer, zooals ik dit van Anakala meedeelde, is algemeen; aan de geesten in het marapoehuis wordt daarbij om een zegen gevraagd.

Enkele houtsoorten mogen nooit voor huisbouw gebruikt worden. Boven noemde ik reeds koendjoer. De radja van Lewa vertelde mij, dat eens in den ouden tijd, toen het nog niet verboden was dit hout te gebruiken, een voornaam persoon het voor zijn woning liet aankappen. Korten tijd daarna werd 
hij van overspel beschuldigd. Deze onaangenaamheid schreef men toe aan het gebruik van koendjoer, en daarom verbood men het te gebruiken behalve voor de andoeng. Sommigen zeggen zelfs, dat men zeere oogen krijgt als men dit hout aanraakt. Alleen voor marapoehuizen mag het worden aangewend. Sandelhout is ook voor huisbouw verboden; dit mag niet eens worden gekapt.

Om de vier palen worden nog vele kamertjes gebouwd; de inrichting verschilt bij de huizen onderling, maar ze doet tot het wezen der zaak niets af. De hierbij gevoegde plattegrond is die van het huis van den radja van Lewa. Dikwijls loopt er om

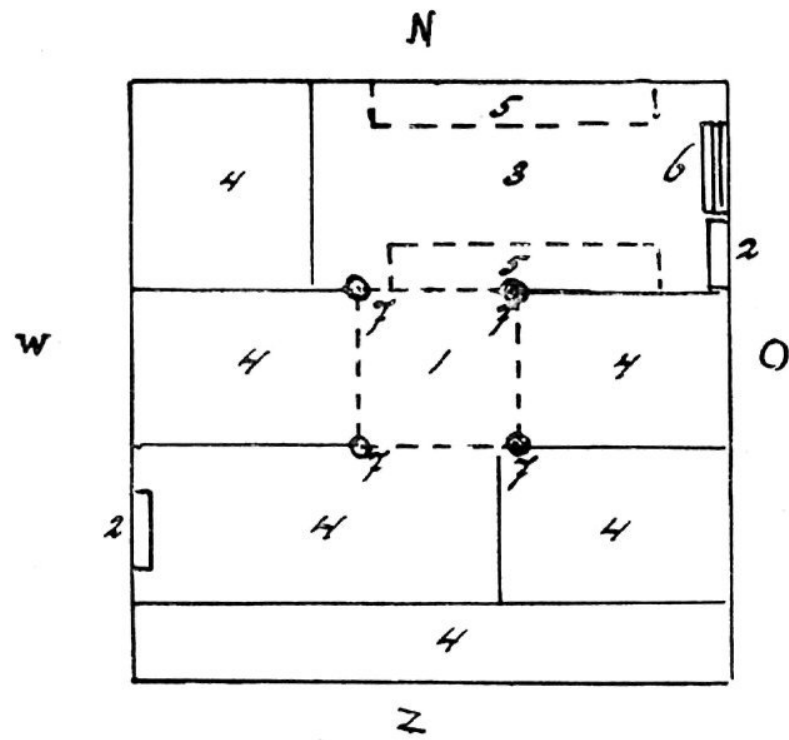

Plattegrond van de woning van den radja van Lewa.

1. stookplaats, a'oe; 2 . deur, pindoe; 3 . ontvangkamer; 4. woon-

en slaapvertrekken; 5 . rustbanken; 6 . offerrekje, ja rang; 7 . de hoofdpalen, kambaniroe; die in den Noordoosthoek de kambaniroe oeratoeng.

het huis nog een smalle open galerij. De richting van de nok is dikwijls Noord-Zuid, maar niet altijd. In het Westen staan de huizen om de nâtara, dorpsplein, geschaard, zoodat geen bepaalde windrichting in acht genomen wordt. De deuropening vond ik naar alle richtingen gekeerd; meestal heeft de woning verscheidene deuren. Maar in Kambera en Lewa schijnt de 
hoofddeur wel aan de Oostzijde te zijn bij den NO. paal; daar bevindt zich ook het offerrek, jarang. Een lijk wordt door deze hoofddeur naar buiten gebracht, want gedurende den tijd dat het boven aarde staat, ligt of zit het op een der rustbanken, die in de ontvangruimte, waartoe deze deur toegang geeft, aanwezig zijn.

Bij het dekken van een huis in Lewa, worden eerst de vier hoeken der woning met alang-alang belegd. Vervolgens dekt men een strook in elk lengtevlak, en daarna eerst worden de overige ruimten van het dak gedekt.

In Lewa wordt de stookplaats eerst belegd met pisangbladeren, en pisangbast; daarop worden een goudschilfer en een steen gelegd; er omheen is een opgerold touw geschikt; dit noemt men het hart en de navel van den haard. Daarna wordt de ruimte aangevuld met aarde, waarbij niet geteld wordt hoeveel manden vol men er in stort. Op deze groote stookplaats staan een aantal komforen opgesteld, elk bestaande uit drie overeind staande steenen, waarop de kookpot wordt geplaatst. Alleen onder den haardsteen, die zich het dichtst bij den hoofdpaal bevindt, wordt een goudschilfer gelegd. Voor gasten zijn meestal stookplaatsen in de hoeken van de woning aangebracht.

Wanneer een aarden kookpot breekt, is dit een teeken, dat Marapoe over het een of ander boos is en daarbij denkt de Soembanees het eerst aan het uitoefenen van ongeoorloofde huwelijksgemeenschap. Dan moet men met de lans wichelen om te weten te komen, wat Marapoe tot toorn heeft verleid, want als deze boosheid niet spoedig wordt verzoend, zou ziekte daarvan het gevolg zijn. Wanneer dan ook een pot breekt, kort voordat men van plan was op reis te gaan, stelt men den tocht nog enkele dagen uit.

Voor een woning waarin de stam-marapoe vereerd worden, gelden nog eenige bepalingen: daar mag niet geweven worden; men mag er geen brandhout hakken; men breke daar niets van het dak of de omwanding af om daarmede de tanden te stoken want deze zouden daarvan slecht worden. Wanneer er een begin van brand is, is het eerste wat men doet: naar boven klimmen en de marapoe-voorwerpen redden. Verbrandt de woning, dan heeft er een plechtigheid plaats, die moet dienen om het verbrande hout koel te maken; d.i. de kwade invloed die dezen brand heeft doen ontstaan, en die ook nog andere huizen in de 
asch zou kunnen leggen, moet geneutraliseerd worden. Er wordt gebeden, alles wordt met water begoten, de asch wordt weggeveegd, en daarna eerst mag men opnieuw gaan bouwen.

Voor die nieuwe woning moeten de marapoe- voorwerpen opnieuw worden bijeen gebracht. Daartoe neemt men een klein stukje van de marapoe uit het stamhuis, en verder knutselt men er zelf aan; goudschilfers en steentjes zijn de voornaamste onderdeelen er van. Men doet dit gewoonlijk na den oogst. In Lewa gaat dit op de volgende wijze. Men neemt twee klossen mais, enkele aren rijst en het hart van een varken dat voor deze gelegenheid is geslacht. Dit alles wordt in de nieuwe woning gereed gezet, en daarbij wordt gebeden. Vervolgens strooit men rijst om de nieuwe woning heen en tamarinde-water wordt in den omtrek gesprenkeld. Ten slotte worden dewa ina en dewa ama (de zielen der gestorven bloedverwanten) aangeroepen, en dan eerst wordt het marapoe-mandje boven in de nieuwe woning op zijn plaats gezet.

Vuur. Het eerste vuur dat in de nieuwe woning wordt gebracht, behoeft daartoe niet opzettelijk gemaakt te zijn met de vuurboor, kohi, of met den vuurslag, tila. Men mag ook vuur uit een andere woning in het nieuwe huis overbrengen.

Over de wijze waarop men aan vuur gekomen is, bestaan nog enkele verhalen. In Anakala vertelde men mij van Oemboe Seboe, van wien boven reeds sprake is geweest, als degeen, die zich over de steenen brug van Sasar naar de overzijde van de zee begeven had, en die in dit verhaal den bijnaam heeft van «zoon van de maan, zoon van de zon»; hij wordt ook gezegd de vader te zijn van Bokoe Dangi, die met zijn vrouw Apoe Lawa het toezicht heeft over de zielen in de doodenstad. Deze Oemboe Seboe nu zou volgens dit verhaal over de steenen brug naar Soemba gekomen zijn en de kunst om vuur te maken met zich hebben meegebracht.

De Evangelist Thimotheus, afkomstig uit Memboro, een landschap, dat ik niet heb kunnen bezoeken, vertelde mij het volgende. In den ouden tijd leefden er zoowel menschen op de aarde als in den hemel, maar alleen de hemellingen kenden vuur, terwijl de aardbewoners hun wortelen en bladeren rauw aten. Toen gebeurde het eens, dat eenige hemelbewoners aan het jagen waren en een varken achtervolgden. Het dier sprong in een kuil en de jagers lieten zich in de opwinding van de jacht 
ook daarin vallen. Door dit gat kwamen varken en menschen op de aarde terecht, waar de vervolging werd voortgezet, en waar het wild weldra geveld was. Toen dit gebeurd was, zagen de aardbewoners, dat de hemellingen vuur maakten en hun buit daarop gereed maakten. Eerst durfden ze niet nader komen, maar langzamerhand vermanden ze zich. Ze proefden van het gebraad, en vonden het zeer smakelijk. Zoo leerden zij dan van de hemelbewoners met vuur omgaan en hun spijzen te koken en te roosteren.

Het tatoueeren op Soemba, waarvan ik een en ander in mijn reisverhaal heb verteld, staat in geenerlei verband met vuur. Op dezen regel is echter een uitzondering, en dit is Laura. In verschillende opzichten vertoonen de gebruiken van dit landschap sterke overeenkomst met die van de Timoreezen. Nu ook weer hierin, dat de menschen van Laura, evenals genen, beweren, dat zij met de tatoutage, welke op hun armen is aangebracht, vuur koopen in de doodenstad, wanneer hun ziel daarheen is overgegaan.

Ik acht het niet ondienstig hier in het kort weer te geven het verhaal, hoe de Savoeneezen, die zeer nauw aan de Soembaneezen verwant zijn, aan vuur zijn gekomen; een verhaal dat door Wielenga in extenso is medegedeeld in de Macedoniër XV, 1911, blz. 235 e. v. De eerste menschen op Savoe waren Rai jae en zijn zoon Djawi rai; beiden waren uit de zee op het land gekomen, en zij voedden zich met wortels die ze in het bosch zochten. Zij aten ze rauw, omdat zij nog niet wisten hoe ze vuur konden maken. Toen kwam er een vrouw uit den hemel, die Kahi Nakoe heette, maar zij verscheen in de gedaante van een bruin varken. Het gelukte Rai jae het dier te vangen, waarna hij het aan hunne hut vastbond. Na dien tijd vonden de mannen, als zij van hun dagelijkschen tocht thuiskwamen, hunne wortelen gekookt, en deze smaakten hun zoo heel wat beter, dan toen zij ze rauw moesten verwerken. Om te weten wie ze kookte, en hoe dit gebeurde, gingen ze op de loer liggen. Toen zagen ze dat het varken een vrouw werd; ze zagen ook hoe vele vliegen bezig waren vuur te maken door stukjes hout tegen elkaar te wrijven.

In het scheppingsverhaal van Masoe (in Taboendoeng) wordt verteld, dat toen de aarde (dit is het eiland Soemba) pas gemaakt was, het er zeer nat was. Toen bracht iemand vuur uit 
den hemel op de aarde, waardoor deze opdroogde. Maar dit vuur werd weldra zoo heet, dat men het moest bezweren met rauw vleesch en met water. Daarom doet men dit altijd nog wanneer de aarde te warm dreigt te worden dour ongeoorloofden coitus (Macedoniër XIV, 1910, bl. 333).

Hond. Het is hier de plaats om een en ander te zeggen van de huisdieren. Van den hond hebben wij nu en dan reeds iets gehoord. In tegenstelling met Timor is op Soemba de hond het offerdier bij uitnemendheid. Maar het verdient opmerking, dat de lever van dit dier in de Oostelijke landschappen van Soemba nimmer voor divinatie-doeleinden gebruikt wordt. Gewoonlijk wordt samen met den hond ook een hoen geslacht, en de ingewanden van dezen vogel worden dan onderzocht. In diezelfde landschappen is het verboden om hondenvleesch aan de marapoe voor te zetten, terwijl het daar toch algemeen door de menschen gegeten wordt. Komt men nu naar het Westen voorbij Anakala, dan vindt men, dat in Lauli, Wanoekaka, Lamboja en Wajewa de levers van honden denzelfden dienst doen, als die van buffels, varkens en hoenders, en dat van die levers even goed aan de marapoe wordt te eten gegeven. We hebben hier dus weer een van de verschillen, die tusschen Oost en West bestaan, en dit verschil moet weer zijn ontstaan te danken hebben aan vreemden invloed.

Over het geheele eiland eet men hondevleesch. $\mathrm{Zij}$ die het niet eten, laten het omdat ze er een tegenzin in hebben. Toch vertelde men mij hier en daar, dat er ook menschen zijn, voor wie het eten van hondevleesch verboden is. Zoo is er een geslacht, kabisoe, te Taroeng in Lauli, welks leden geen hondevleesch mogen eten, "omdat hun marapoe (stamvader) een hond was». Een nadere verklaring hiervan wist men mij niet te geven; voor deze lieden is het ook verboden een hond te dooden. Zoo ook in de hoofdplaats van Lamboja: daar eten van de vier geslachten, drie geen hondevleesch. Hier kon of wilde men mij de reden er van niet mededeelen. In de onderafdeeling Baliloko van Wajewa is ook een geslacht dat geen hondevleesch mag eten. Als reden daarvoor gaf men mij op, dat eens in den ouden tijd een vrouw van dit geslacht zich met een hond had afgegeven, en uit schaamte daarover had zij zich van het leven beroofd. Daarom zouden de leden van haar kabisoe geen hondevleesch meer eten. Boven is ook reeds 
sprake geweest van een vrouw in Wajewa, die het met een hond hield. Ditzelfde vertelt men ook in Pajeti: daar eet men geen hondevleesch uit afschuw, omdat een vrouw van het aldaar wonende geslacht zich in den ouden tijd met een hond had afgegeven. Haar misstap was gebleken uit het feit, dat er hondeharen uit haar sarong waren gevallen.

Een ander verschil tusschen Oost en West bestaat hierin, dat in Oost-Soemba de kop van een hond nooit gegeten wordt; deze wordt weggeworpen. In West-Soemba daarentegen gooit men niets van het dier weg.

Een hond mag nimmer geslacht worden, d.i. met een mes of een zwaard gedood worden. De gewone wijze waarop men een eind aan zijn leven maakt, is dat men het dier te eten geeft, en terwijl het zich aan het maal te goed doet, slaat men hem met een stuk hout voor den kop dood.

Wij hebben reeds gezien welk een voorname rol de hond speelt bij het "ontzondigen» van lieden, die bloedschande hebben gepleegd. Ook hebben wij gezien, dat vrij algemeen de gewoonte bestaat, om bij een sterfgeval dadelijk een hond te dooden. Wanneer een hond over het lijk van een mensch springt, is dit een bewijs, dat de doode bloedschande heeft gepleegd, maar zijn daad niet heeft willen bekennen. Dan wordt het lijk nog gauw ontzondigd, opdat de hond, die volgens de verhalen in Oost-Soemba de parai marapoe of het doodenland bewaakt, hem niet verjage.

Wanneer men in het Oosten een boschland ontgint, is het eerste dat men doet een hond dooden, om de boomgeesten, die op de te ontginnen plek mochten wonen, te verzoenen. Zoo ook in West-Soemba: de hond wordt aan den kant van het te ontginnen veld gedood. Nadat zijn lever is onderzocht, wordt het vleesch verdeeld onder de deelnemers, en de onderkaak wordt aan een staak opgehangen bij den steen, die voor den nieuwen akker zal hebben te zorgen. Die steen heet in Wajewa watoe pakatoekoe; in het Oosten alleen katoda; het offer is bestemd voor moeti loda, den aardgeest. Naast de watoe pakatoekoe, "de geplante steen», die overeind staat, is een platte steen neergelegd, de watoe lîmbara, de drempel; op deze laatste wordt het borststuk van den hond gelegd met een stuk van de lever, wat rijst en sirih-pinang. Als men een veld gaat ontginnen, belooft men wel eens vooraf om 
een hond te zullen dooden, als de oogst goed gelukt. Maar in elk geval wordt dit bij den oogst gedaan als deze goed is uitgevallen. In Oost-Soemba wordt bij elke oogst van wata roe hamoe, "de gierst", een hond geofferd.

"Bij het oprichten van een marapoe-steen, katoda, wordt een hond geofferd, heb ik voor Oost-Soemba aangeteekend. Oemboe Dong vertelde mij, dat in Anakala bij de geboorte van een vrij kind, ana kabisoe, een jongen of een meisje, een hond wordt gedood; als het lijden kan ook nog een buffel of een varken.

Bij het huwelijk en bij den bruidsschat speelt de hond een rol, want in Lewa geeft de man aan de vrouw bij het huwelijk steeds een hond, en het staat aan haar, of zij het dier wil laten leven, dan wel het dooden. In Anakala moeten, voordat een paar kan trouwen, een hond, een kapmes en een speer worden gebracht, en daarna volgt eerst de eigenlijke bruidsschat. De hond draagt den naam van asoe woelan, asoe ladoe, asoe mangoma, asoe palai, "de hond van de maan, de hond van de zon, de hond van het een vrouw nemen, de hond van het een man nemen». Men vertelde: Wanneer deze hond niet bij den bruidsschat wordt gegeven, zal het paar nooit geluk (voorspoed) hebben, en als de ziel van een hunner in het doodenland, de parai marapoe, komt, zal de daar wakende hemelhond haar bijten. Ook in het Westen, in Wajewa, moet bij een huwelijk de man een varken en de vrouw een hond dooden.

Ook bij het verdrijven van ziekte moet de hond dienst doen. Zulk een plechtigheid heet in Oost-Soemba: paloehoe maranga, "de verkoudheid er uit jagen». Bij deze gelegenheid roept een oude man den geest, die naar de voorstelling langs de andoeng (de paal voor de gesnelde koppen) naar beneden komt. Twee mandjes zijn daar neergezet, af komstig uit de woning van den kranke; het eene is gevuld met gekookte, het andere met ongekookte rijst; beide mandjes zijn aan elkaar gebonden met gekleurd garen. Ook worden den ouden man eenige schilfers goud gegeven. Beide mandjes heft hij op en bidt er bij. Heeft hij dit gedaan, dan wordt hem uit het huis, waarvan die mandjes afkomstig zijn, een reeds geroosterd kuiken gebracht. Dit scheurt hij open, en kijkt de ingewanden na of deze goed voorspellen. Het kuiken wordt daarna in een der mandjes gelegd. Daarna wordt een jonge hond gebracht, die wordt dood- 
geslagen. Nu zijn de offeranden gebracht. De leider van de plechtigheid neemt de mandjes op en trekt daarmee plechtig het dorp door, gevolgd door een jongen, die den dooden hond aan een touw voorttrekt, en een man die rustig op de trom slaat. Vrouwen en kinderen maken groot lawaai; ze schreeuwen en gillen, slaan op de wanden der huizen, alles om den ziektegeest weg te jagen. Zoodra de oude man buiten het dorp is gekomen, houdt het leven op: de ziektegeest is heengegaan, en hij wordt nu met de offeranden ver buiten het dorp gebracht, waar alles in een ravijn wordt geworpen (Macedoniër XII, 1908, bl. 108-110).

In Anakala heet deze plechtigheid: palaoesoe bani tana, "de boosheid der aarde verjagen». Hier wordt de gedoode hond ten slotte bij een pisangstam bij het dorp begraven. Ook in Wajewa wordt bij ziekte een hond gedood. Voor den kranke wordt eerst bij de pari'i marapoe (hoofdpaal van het huis), gebeden; dan wordt de hond beneden op den grond doodgeslagen en zijn lever onderzocht en daaruit wordt opgemaakt of de zieke zal herstellen of niet. De hond wordt niet weggebracht, maar zijn vleesch wordt door het gezin opgegeten.

De hond wordt voor de jacht gebruikt. Wanneer men in Wajewa van een gelukkigen en grooten jachttocht is teruggekeerd, wordt een hond geslacht voor Marapoe Penda, die gezegd wordt voor het wild te zorgen. De lever van den hond wordt onderzocht om daaruit op te maken, of men de volgende maal ook zoo gelukkig op de jacht zal zijn. Het borststuk van den hond en de nieren worden voor dezen marapoe op een mat in de woning neergelegd, en de rest van het dier wordt opgegeten.

Ook op Soemba wordt op de bewegingen van den hond gelet. Overal neemt men aan, dat als een hond in huis urineert, defaeceert of braakt, in die woning overspel of bloedschande moet zijn gepleegd. Of zoo iets kan ook te kennen geven dat er in dat huis gestolen is. In Wajewa komt men tot dezelfde gevolgtrekking, wanneer een hond een gat in de aarde van de stookplaats graaft. De lans moet dan gevademd worden, om daarmee uit te kunnen maken, wat gebeurd is. De hond wordt er niet om gedood. Wanneer hij een poging doet om tegen iemands been te urineeren, is dit een bewijs dat die persoon iets op zijn geweten heeft, en wanneer hij zijn fout niet bekent, tracht men 
er door de lans achter te komen. Huilt (a o eloe) een hond, dan wordt dit aangemerkt als een teeken dat een familielid ernstig ziek of gestorven is. In Wajewa zegt men, dat er dan een groote der aarde, een vorst zal sterven.

Kat. Naar aller getuigenis komen katten, meo, wodoe of wodo, weinig op Soemba voor. Het kan ook niet zoo lang geleden zijn, dat men ze op dit eiland heeft leeren kennen. In Napoe wist men nog, dat het eerste kattenpaar van Waingapoe werd aangebracht. Zoo vertelde men ook in Anakala, dat men de eerste exemplaren van die dieren uit Lauli heeft gehaald. Volgens Oemboe Dong zou de voorvader Oemboe Dangi de eerste kat van Djawa (= uit den vreemde) hebben meegebracht.

Men mag niet zeggen een kat te "koopen», maar men komt tot den eigenaar van katten om zulk een dier te "trouwen». Men geeft voor een kat ook een bruidsschat, banda, dit is een gulden of een halven gulden. Men neemt de kat in den arm of in een sarong gewikkeld mee naar huis, en men geeft het dier bijnamen als Ramboe Kahi voor een wijfje en Oemboe Ndeloe voor een mannetje, of, zooals in Wajewa: Koni, en Koeri lele. Als men een kat in Oost-Soemba heeft thuis gebracht, roept men: "Hier is de ana momoha" (het meisje dat bij een voornaam huwelijk voor bruid moet figureeren). In sommige landschappen wordt de kat eenvoudig de trap op in huis gebracht; in andere steekt men haar door een gat in den vloer bij de haard naar binnen. In Lakoka strooit men gestampte rijst over haar heen en men geeft haar dadelijk te eten. In Napoe wordt ze ontvangen met een eigenaardig gillen der vrouwen, waarmee dezen een werkelijke bruid plegen te begroeten, en in Wajewa slaat men bij haar komst op een bamboe. In Anakala vangt men, als een nieuwe kat gebracht is, twee sprinkhanen, $\mathrm{kabala}$. Deze worden geroosterd; daarna legt men de eene op een portie rijst, die voor de kat bestemd is en de andere in de mand, die men voor haar als slaapplaats gereed gemaakt heeft. Deze laatste sprinkhaan zou tot de kat zeggen: "Hier zijn gongs, hier is rijst, en er zijn nog veel andere dingen, daarop moet gij passen!,

Overigens toont men niet veel eerbied voor de kat te hebben: kinderen plagen haar. Men zal haar niet spoedig slaan of haar aan de staart trekken, alles uit vrees, dat zij zal wegloopen. Vooral het slaan met een pollepel is gevaarlijk. Men mag haar 
niet schelden, en als men zich eens vergeten heeft, vraagt men haar vergeving en zegt: " Ik heb u niet gescholden, maar de muizen». Daarom ook geeft men er haar kennis van, wanneer een der huisgenooten overleden is, want zoo men dit niet deed, zou zij naar een andere woning gaan. Men heeft allerlei middelen om haar aan huis te binden: zoo kauwt men een stukje geroosterd kokosvleesch, en geeft dit aan het dier te eten.

Allerlei zaken moet men in acht nemen, wil men een kat lang in huis houden: alang-alang van het dak, bamboe, kokosdoppen, mag men niet op den haard branden dan nadat men er eerst aan poes verlof voor heeft gevraagd. In Lakoka mag ook geen oeloe takoe-hout op den haard komen. Paardevleesch mag niet aan de kat te eten gegeven worden; zoo ook garnalen, koerang, niet; snoept ze uit zichzelve van de laatste, dan kan het geen kwaad, maar in Anakala bijvoorbeeld worden de resten van garnalen zorgvuldig verzameld en begraven. Sommigen geven haar ook geen kippe- en geitevleesch, want daarvan zou ze dol worden en wegloopen. Algemeen ook is het verboden om als een kat gejongd heeft, er naar te gaan kijken en de jongen te tellen; men gelooft dat de moeder dan zal ophouden haar kleinen te zoogen. Als ze een muis gevangen heeft, moet men haar die niet afnemen, want dan zou ze niet meer vangen.

Ook wanneer een kat sterft, toont men haar niet den minsten eerbied. Het cadaver wordt eenvoudig weggeworpen, en daar waar het begraven wordt, geschiedt dit alleen met de bedoeling, dat de honden het niet te pakken zullen krijgen en het verscheuren, want men denkt, dat de hond dan in de haren van het dier zal stikken.

De kat speelt ook geen rol in de voorstellingen van het Hiernamaals. Alleen in Anakala zei men mij, dat in de doodenstad een groote, witte kat zou zijn, die muizen vangt voor de doodenzielen.

$\mathrm{Buffel}$. Wat de overige huisdieren betreft, in mijn reisverslag heb ik al een en ander van het paard, ndjara, verteld. Van het varken, we, wej of waj, wist men mij alleen in Anakala te vertellen, dat de eerste twee varkens Laworoe, "rood gestreept», en Bara lagi, "wit op de heup», waren geweest. Ze waren door Oemboe Kawoloe op Soemba gebracht. Hier moet nog iets volgen van den buffel, karambo'a, karambo, in Lakoka ook: ka oe.

De verhalen omtrent den oorsprong der buffels zijn op Soemba 
niet zoo menigvuldig als op sommige andere eilanden van de Timorgroep. In Oost-Soemba weet men alleen te vertellen, dat de eerste buffel uit den hemel zou zijn gekomen, en dat de hemelling, die het dier voortdreef, daarvoor een sandelhouten stok gebruikte. Dezen stok stak hij in den grond, en dit werd de eerste sandelhoutboom op dit eiland. (Wielenga heeft aangetoond, dat ai nitoe, de naam voor sandelhout, niet "geestenboom» beteekent, zooals gewoonlijk wordt gedacht, naar het algemeen in den Archipel voorkomende woord nitoe en zijn varianten, die 'geest, doodenziel, beteekenen, maar ai nitoe wil zeggen shout met tal van wortels. Naar de voorstelling van den Soembanees woont er geen geest in dezen boom. Een klein stukje sandelhout maakt hem, die het bij zich draagt, onkwetsbaar, maar dan moet hij er met iedere volle maan een witten haan aan offeren. (Macedoniër XIV, 1910, bl. 200). Het eerste buffelpaar zou volgens Oemboe Dong van Anakala heeten: Pawairi poenggoe nali (het mannetje), en Timbaloe lokoe bakoel (het wijfje).

Ook de Soembanees weet te vertellen, dat de buffel eertijds een mensch zou zijn geweest. In Kambera verhaalt men, dat eens eenige lieden een akker bewaakten. Toen zij niet meer te eten hadden, gingen zij naar den radja om eten te vragen, maar deze antwoordde hun: "Dan moet gij maar gras eten». Toen de wakers op den akker teruggekomen waren, braken ze het spinnewiel stuk, staken zich een paar spaken daarvan als horens in het hoofd, en de spoel achter in den rug als staart. Toen gingen ze werkelijk gras eten. Zoo veranderden ze langzamerhand in buffels. Slechts één hunner had dit niet gedaan en was mensch gebleven. Toen de radja na een poos in den tuin kwam, vroeg hij waar al zijn menschen waren gebleven. Hij werd op de grazende buffels gewezen, en men zei hem: "Het is uw schuld dat ze dieren zijn geworden, want ge hebt hun gelast gras te eten». De radja betreurde zijn woorden toen zeer. Toen de dieren hem zagen, kwamen ze op hem af, vielen hem aan en doodden hem.

Er zijn allerlei verhalen van deze dieren in omloop. Zoo vertelt men van iemand, die zittende op een buffel van Soemba naar Savoe overstak. Overal waar hij langs trok, scheidde de zee zich, zoodat er een pad gevormd werd, waarlangs het dier droogvoets kon gaan. In Kanatang vertelt men, dat daar eens 
een buffelkoe de lieden toesprak, die haar jong wilden slachten: "Waarom wilt gij mijn jong slachten; gij hebt al twee van mijn kinderen gedood, en nu wilt gij ook het derde van mij nemen . De menschen werden zon bevreesd op het hooren van de stem, dat zij het jong loslieten.

Boven is reeds gezegd, dat voor buffels en paarden ook steenen, katoda, worden opgericht, die voor het welzijn van deze dieren moeten zorgen. Zelfs bij de weideplaatsen bevinden zich die steenen ${ }^{1}$.

De buffel is het meest geschatte offerdier; een buffel is het hoogste dat men den geesten kan geven. Men vertelde mij dat een vorst van Anakala eens vijftig buffels had geslacht bij het leggen van een sawahdijkje door een stuk heilig land voordat de geest, die daar heette te wonen, er genoegen mee nam, want eerst bij het vijftigste dier werd de lever in orde bevonden. De horens der buffels worden meestal gebruikt om er handvaten voor hakmessen en dergelijke voorwerpen van te maken; alleen van die beesten, die bij de oprichting van een woning worden geslacht, worden de horens aan de stijlen van het huis gebonden.

Buffels moeten den grond van de natte rijstvelden vertreden, om hem murw te maken; dit werk treedt dus in de plaats van ploegen. Het heet padili latang. Wanneer het is afgeloopen, moeten de pooten der dieren eerst "verkoeld» worden, voordat een hunner mag geslacht worden. Hierbij wordt een kip geofferd en gebeden, terwijl de pooten besprenkeld worden met water waarover eerst gebeden is. De buffel die aan den ratoe wordt gebracht om te worden geslacht ten einde regen te vragen, draagt den naam van lending kamotoe (lending=over iets heenloopen; $\mathrm{k}$ a motoe $=$ dijkje). Wanneer de rijst vrucht heeft gezet, mag geen buffel meer langs den akker worden geleid.

Buffelvleesch wordt algemeen gegeten, en men maakt daarbij geen onderscheid tusschen het vleesch van witte en dat van zwarte dieren. Het behoort tot de goede gewoonte om een gast, dien men eeren wil, "een kuiken , aan te bieden, waarmee dan een jonge buffel is bedoeld.

$\mathrm{R}$ ijst. Zooals elders reeds is opgemerkt, wordt in West-Soemba veel meer aan rijstbouw gedaan dan in het Oosten van dat land.

\footnotetext{
1 Deze katoda is een zuivere offertafel en er wordt gebeden en geofferd tot den marapoe ndjara of marapoe karamboa. W.
} 
Voor een groot deel, zal dit wel hieraan liggen, dat in het genoemde deel de gronden meer geschikt zijn voor rijstcultuur dan elders. Maar ook mag worden ondersteld, dat in het Oosten de landbouw min of meer verwaarloosd is geworden om de paardenfokkerij. En als derde reden mag worden genoemd, dat door de tirannie der radja's in het Oosten, de rijstbouw daar niet tot bloei is kunnen komen.

Er bestaan heel wat verhalen over den oorsprong van de rijst, en ofschoon die overleveringen vrijwel denzelfden zin hebben, is het wel de moeite waard ze bij verschillende landschappen na te gaan. We moeten daarbij ook de aandacht vestigen op het verschil, dat tusschen rijst voor natte en die voor droge velden gemaakt wordt.

In Oost-Soemba is Taboendoeng het land waar het meest aan rijstcultuur wordt gedaan. In den ouden tijd, toen men nog geen rijst kende, leefde daar een vrouw, die Bandja Oeroe-oeroe naoe heette. Haar man droeg den naam van Patingoeroe ngoeroe mbana, maka woeroe naoe. $\mathrm{Zij}$ waren broer en zuster. De vrouw was zwanger. Later beviel ze van een levenloos kind, en ook zij zelve stierf ten gevolge van de bevalling. Haar man wilde haar nu gaan begraven, maar overal was de grond te hard om er een gat in te kunnen maken. Slechts op één plek was dit mogelijk, en wel vlak voor de woning. Daar werd het graf dan ook gedolven. Toen het gereed was wikkelde Patingoeroe het lijk in een sarong en liet het in zittende houding in den kuil neer, zonder eenig ceremoniëel, omdat men dit nog niet kende. Gedurende den nacht brak er een verschrikkelijk onweer los; de bliksem was niet van de lucht, zoodat de honden van angst blaften, en de hanen kraaiden. Toen het morgen geworden was, klom zekere Oemboe Kadoe naar den hemel op om bij den maramba bokoel "groote vorst", te onderzoeken wat de reden mocht zijn van deze boosheid der natuur. De Groote Heer in den Hemel antwoordde aan Oemboe Kadoe: "Gijlieden hebt de vrouw verkeerd begraven; haal haar weer uit den grond en doe haar in zittende houding in een kist; als zij in de kist is, moet gij haar in de zij tasten». Alles werd gedaan, zooals de Hemelheer had bevolen, en toen Oemboe Kadoe de vrouw in de zij gegrepen had, vielen er rijstkorrels uit, van alle soorten. Op last van Maramba bokoel werden deze korrels op de aarde van de stookplaats uitgeplant, en toen men de vrucht daarvan geDl. 78 . 
oogst had, werd die rijst uitgedeeld en zoodoende over het land verspreid.

Toen ging Oemboe Kadoe weer naar boven om te vertellen dat alles geschied was, zooals Maramba bokoel dit had gelast. Daarop zeide deze: «Plant een paal op het graf der vrouw, en hang daaraan de koppen van een woudduif (mbara), van een rijstdiefje (mamingoe), van een paard en van een buffel; kom mij daarna vertellen of het mooi staat». Toen Oemboe Kadoe naar de woorden van den Hemelheer had gedaan, ging hij hiervan aan dezen kennis geven, en hij voegde er bij, dat de versiering niet mooi stond. Toen gelastte de Hemelheer aan Oemboe kadoe om al die koppen weg te nemen, en daarvoor een apekop in de plaats te hangen. Dit deed de man en hij vond dat het heel fraai stond. Toen Maramba bokoel dit had vernomen, gaf hij aan Oemboe Kadoe een lans en een schild, en gelastte hem daarmee Patingoeroe te dooden. Toen hij dit gedaan had zette hij het hoofd van den verslagene in de plaats van den kop van den aap, en toen zag Oemboe Kadoe, dat dit eerst recht mooi stond. Het lichaam van Patingoeroe werd in tweeën gedeeld en gevild: uit de huid, de maag en de ingewanden ontstonden de kabisoe-geslachten. Het vleesch en de beenderen van het lijk werden op een hoop geworpen (paboendoeng, waaruit de naam van het landschap verklaard wordt), en daaruit ontstond het vorstengeslacht van Taboendoeng.

Hierna komt er een tegenstrijdigheid in het verhaal, zooals radja Oemboe Dai mij dit vertelde: Vóór het gebeuren met de vrouw zou er al rijst zijn geweest en wel rijst van de droge velden. Deze had oorspronkelijk een geheel ronde korrel; ze heette oehoe woroe=rijst die zich vermeerdert. Deze naam had zij te danken aan de omstandigheid, dat al kookte men er een klein stukje van, dat men met den nagel er af knipte, dit toch een pot vol rijst werd. De rijst die uit de zijde van de vrouw kwam, werd rijst van de natte velden. Deze twee soorten worden nooit bij elkaar opgeborgen of met elkaar vermengd gekookt. In Wanoekaka zei men, dat als beide soorten in één schuur werden opgeborgen, ze samen zouden gaan vechten; menschen die ze dooreen gemengd eten, zouden er ziek van worden.

Ook in Laura vertelt men, dat beide rijstsoorten van verschillenden oorsprong zijn, maar welke van de twee oudste zou 
wezen, wist men niet te zeggen. Men zei wel, dat de marapoe van de droge akkers veel strenger zijn, dan die van de sawahs, want bij het bewerken van de laatste was het niet zoo noodig om alle voorschriften in acht te nemen als bij de bearbeiding van de eerste. Zoo mag de rijst uit de tuinen niet gegeten worden, voordat het heele veld is afgeoogst, en er voor den oogst gebeden en geofferd is; maar met sawahrijst komt het er niet zoo erg op aan. In den zang van de rijst wordt gesproken van: Pari koni, pari Ndima (Ndima is Bima), maar dit slaat zoowel op rijst van droge als van natte velden.

Voordat wij rijst hadden, zei men in Anakala, aten we lipi en kapapang, twee groentesoorten, die in het wild groeien. (Dit vertelde men mij ook in andere landschappen). In Anakala wordt deze lipi, loepi kadi genoemd. Oemboe Dong noemde ook nog als eerste voedingsmiddelen: kabai moroe (katjang hidjau) en kadapoe. Dit laatste is Colocasia, en de dichterlijke omschrijving van deze plant op Soemba luidt: Kadapoe padongoe daung wia pakodja kiri, van welke woorden ik geen vertaling kan geven. Sagoe, boeloeng, wordt behalve in Anakala ook in Wanoekaka en Lawonda gevonden, maar ik heb mij niet kunnen overtuigen, of dit wel de Metroxylon is. Men hakt met een kapmes brokken van het merg uit den boom; deze stukken worden bij het vuur geroosterd en gegeten. Voordat de boomen worden omgehakt, komt de ratoe er bij om den marapoe aan te roepen. Men danst (rendja) om den boom, en de krijgskreet wordt aangeheven, waarna de boom wordt geveld. Men eet dit sagoemerg alleen in tijden van groote voedselschaarschte.

Ladangrijst mag niet op sawahs geplant worden, en omgekeerd sawahrijst niet op droge akkers. In oe malari heet de rijst van de sawah afkomstig, die bij het offeren aan den marapoe wordt voorgezet; de bedoeling van dit offer is, zegt men, dat de rijst niet zal wegloopen. Ladangrijst mag ook in het marapoe-huis worden gebracht en gegeten. Op een plek, die Poenggoe Laba heet, zou de eerste droge rijstakker zijn gemaakt. Oemboe Kawoloe was het die de eerste sawah aanlegde, en wel te Pasi koeroe watoe toemboe takaneki, dicht bij Parai Madeta in Lawonda. Die sawah bestaat nog steeds, en de radja van Lawonda laat haar bewerken. Van Anakala is er een sawah der voorouders, laka marapoe, bij Tari kodi. Wanneer het $\mathrm{njamba-feest}$ gevierd wordt, eten allen van de opbrengst er van, zoowel vrijen 
als onvrijen. Van de rijst van dit veld wordt ook aan den stammarapoe geofferd. Men neemt van hier ook graag zaairijst voor zijn eigen akkers. Als het genoemde veld bewerkt zal worden, komen daartoe alle menschen bijeen en aller buffels worden er op samengedreven.

De oude Oemboe Dong van Anakala vertelde mij, dat de meer genoemde voorvader Oemboe Seboe een zuster had, Ramboe pari mboka, "Jonkvrouw vette rijst», geheeten. Toen beiden langs een ijzeren ladder naar de aarde afdaalden, viel het meisje naar beneden en was onmiddellijk dood. Uit haar groeide de sawahrijst op. De tuinrijst en de mais werden op aarde gebracht door Ramboe Mambal. Dit meisje had drie broers en drie zusters. De eersten droegen de namen van: Noenoe, Ngongoe en Sawoe baika bani. De zusters waren: Ramboe Podoe, R. Dairoe en $R$. Saoe. Iedere broer huwde met een zuster, maar Ramboe Mambal bleef ongehuwd over. Toen zij stierf groeiden uit haar lichaam allerlei gewassen op, die men gewend is op de droge akkers te planten, in de eerste plaats rijst en mais.

Ook in Lauli laat men beide rijstsoorten elk uit een vrouw voortkomen. Lota lara en Koda laja waren twee broers, die in den hemel woonden. De laatste was gehuwd met Kamoeli mali kegora, en dit paar had een dochter, die Kabida mali mabok heette. Toen dit gezin langs de ijzeren ladder uit den hemel naar beneden daalde, viel de laatste op de aarde en stierf. Uit elk harer oogen groeide een stengel rijst voor droge velden op, en haar lichaam bracht allerlei andere gewassen voort. Oemboe Seboe (die hier voluit genoemd, Oemboe Seboe, Oemboe Tara těnoe isi, těnoe asoe heet) had een dochter, Mali pari genaamd; uit haar lichaam is de sawahrijst opgegroeid.

In Lamboja is het een hemelling, Ladjoelo dede, die de rijst over de aarde strooit; de korrels die op de droge aarde vielen, werden ladangrijst; die op moerassige plekken neerkwamen, waren sawahrijst.

De Savoeneesche Evangelist E. Wadoe vertelde mij, dat men hem in Tana Rioe had gezegd, dat de rijst uit den hemel op aarde was gebracht door Mbiri pari; dit gewas was tegelijk gekomen met mais en katjang.

Ten slotte deel ik nog een verhaal mede uit Memboro, dat mij door den daar geboren Evangelist Timotheus werd verteld. Ina Kalada-Ama Kalada, het hemelsch paar, hadden zeven 
zonen en acht dochters. Iedere zoon nam een zijner zusters tot vrouw, zoodat één meisje ongehuwd bleef. Deze nam toen een muis tot echtgenoot, die zich echter aan haar had voorgedaan in de gedaante van een mensch. Toen zij na hun huwelijk naar hunne woning gingen, bleek het dat deze slechts een hol in een heuvelwand was. De muis ging er binnen maar de vrouw moest er buiten blijven. Ten slotte stierf zij van verdriet en teleurstelling. Anderen zeggen, dat de broers haar in stukken hakten, uit boosheid omdat zij zich aan een muis had verbonden. Uit haar rechterzijde groeide sawahrijst op, uit haar linkerzij ladangrijst; haar haar werd gras; haar tanden mais, en uit elk deel van haar lichaam groeide eenig gewas op.

De ontsmettende, kwaad afwerende, kracht van rijst hebben we leeren kennen uit het strooien er van om een nieuwe woning heen; en bij den terugkeer van een sneltocht, wanneer de strijders er mee worden bestrooid. Dit deed men ook met lieden, die uit hun krijgsgevangenschap waren gevlucht. Wanneer zulk een ontsnapte bij zijn dorp was teruggekeerd, mocht hij niet dadelijk naar binnen gaan, maar hij moest zich enkele dagen op een akker in de buurt ophouden. Een aanzienlijk huisvader (a ma bokoel in Oost-Soemba) offerde en bad bij den hoofdpaal van het huis waarbij hij aan den marapoe kennis gaf van den terugkeer van den dorpsgenoot. Hierna ging hij den vluchteling tot in de poort van het dorp tegemoet, en vroeg hem: "Wie is daar?, Antwoord: "Die en die.» "Wat komt ge doen?» «Ik kom mijn ouders zoeken.» Dan strooide de a ma bokoel rijstkorrels over hem heen, en wierp twee eieren op den grond stuk. Daarna eerst mocht de man binnenkomen.

De magische kracht van rijst komt goed uit in een verhaal, uit Kambera afkomstig, dat mij door den Heer Wielenga werd gedaan. Iemand ging eens op de jacht. Toen hij daarvan was thuisgekeerd, vond hij zijn vrouw overleden. Men gaf hem te kennen, dat als hij haar terug wilde hebben, hij naar de Doodenstad moest gaan, en dat hij een mandje met gewone en een met kleefrijst moest meenemen. In den nacht kwam hij aan de rivier in het Doodenland aan, en dadelijk strooide hij wat van zijn rijst aan den oever. 's Morgens kwamen de zielen der dooden om zich te baden, en door de kracht van de gestrooide rijst was hij in staat om deze anders onzichtbare wezens waar te nemen. Terwijl de dooden zich aan het baden waren, strooide 
hij zijn kleefrijst in het water. Dit had tengevolge, dat al die zielen stierven en door den stroom van het water werden meegenomen. Maar onder hen was ook zijn vrouw. Haar greep hij vast, en trok haar op het land. Gelukkig had hij nog wat gewone rijst over. Dit restantje strooide hij over haar uit met de woorden: "Een deel van deze rijst worde uw hart, een deel worde uw ingewanden, enz.», met het gevolg, dat de ziel der vrouw niet alleen herleefde, maar dat zij ook gematerialiseerd werd. Hij nam haar daarna met zich mee naar huis.

Landbouw. In Midden- en Oost-Soemba zijn de droge akkers veel talrijker dan de natte. De laatste zijn alleen in het bezit van de radja's, terwijl het volk droge velden maakt. Er zijn in het genoemde gedeelte van dit eiland heele streken, waar geen stukje sawah gevonden wordt. In het Westen daarentegen, in Laura, Lauli, Wanoekaka, Lamboja, Kodi, wordt meer aan de natte dan aan de droge rijstcultuur gedaan. Wajewa maakt in het Westen een uitzondering. Daar worden in de onderafdeeling Lêwata wel sawahs gevonden, maar in Baliloko zoo goed als niet. Men zegt dat eerstgenoemde onderafdeeling ouder is dan de tweede. In Lêwata vindt men dan ook sawahs die aan de voorouders zijn gewijd, of die de eerste akkers moeten zijn geweest, de zoogenaamde pamba marapoe, zoo. als ik er boven al enkele genoemd heb, en die ook gewoonlijk het eerst van alle bewerkt worden. Die van Lêwata zijn te Bondo kandeloe en Bondo Kaniki. De bepalingen omtrent het eten van de nieuwe rijst verschillen wel in de distrikten onderling, maar op dit punt stemmen alle overeen, dat de rijst van de marapoe-velden niet mag worden gebruikt, eer alle akkers zijn afgeoogst.

Overal op Soemba is er een leider, die de werkzaamheden op de akkers regelt. In Midden- en Oost-Soemba is dit steeds de ratoe. In het Westen schijnt het ook wel eens een ander te kunnen wezen. Wanneer ik aan de menschen vroeg, waarop gelet wordt om te weten, dat de tijd daar is om de velden te gaan bewerken, was bijna altijd het antwoord: "Wij wachten daarmee tot de eerste regens zijn doorgekomen». Het is alleen de ratoe, die er verstand van heeft, om ook naar den stand der sterren te zien. Oemboe Dong vertelde mij, dat de ratoe die kennis voor zichzelf behoudt; wanneer hij de sterren bestudeert, als er anderen bij zijn, moeten dezen het gelaat met hun doek 
bedekken, anders zou de ratoe ziek worden. Ik heb wel den indruk gekregen, dat men niet veel aan sterrenkijken doet, en opmerkelijk genoeg - wel het minst in het Westen, waar het meest aan rijstbouw, en wel op natte velden, wordt gedaan. Zoo wist men mij daar wel een aantal namen van sterren te noemen, maar hun stand aan den hemel wordt niet gebezigd om daaruit den tijd van het jaar te berekenen.

In Taboendoeng is een ster, die den naam draagt van $\mathrm{kan}$ doenoe tanda ndaun, "de ster die het jaar aangeeft". Welke ster dit is heb ik niet kunnen bepalen. Men zegt, dat die ster een man is geweest, en de kleinere sterren er om heen zijn zijne honden. Wanneer deze ster bij het vallen van den avond wat hoog aan den oostelijken hemel staat, acht de ratoe den tijd gekomen om te beginnen; maar als de regens zich dan nog niet hebben aangekondigd, stelt hij het bewerken der akkers nog wat uit.

De lieden van Kambera spreken van eenige sterren, die ik niet heb kunnen bepalen. Zoo noemen zij twee sterren: kamambi awang, «hemelgeiten. Wanneer deze twee dicht bij elkaar staan, zullen de regens spoedig komen, zijn ze ver van elkaar verwijderd, dan moet men er nog lang op wachten. Een andere ster heet kandoenoe pama karamboa (kand'oenoe is ster); als men deze te middernacht ziet, zegt men dat dan de wilde buffels gaan grazen. Een staartster heet kandoenoe ningoe landoe, "ster die een pluim of kuif heeft». Wanneer zich zulk een ster vertoont, zal er een radja sterven. Wanneer een ster dicht bij de maan staat, heeft er een diefstal plaats. Is er een kring om de maan, dan kruipt een schildpad op het droge om eieren te leggen. Is er maansverduistering of is de maan rood, dan zal een radja sterven.

In Lakoka vertrouwt men op de ster die Oemboe Pati Hina wordt genoemd. Dit is de middelste ster van den gordel van Orion. De eerste is zijn hond, en de derde is de vrouw van den Oemboe, die hem volgt. Die vrouw was zijn zuster, en omdat zij met haar broer was getrouwd, en dus bloedschande pleegde, werden beiden sterren. Ze hadden een kind dat door Oemboe Pati naar den hemel werd medegenomen. Voordat hij naar boven ging, lichtte hij de menschen in, hoe zij acht op hem moesten slaan, opdat hunne rijst zou gelukken.

In Anakala wordt hetzelfde verteld: hier heet de man echter 
Dokoe dewa danga oera; de middelste ster is zijn kind, dat tusschen zijn vader en zijne moeder in loopt. Zoo ook in Lauli: hier heet de eerste Kataroe gede, de vader; de tweede is Ladona mataramoe rara, het kind; en de derde Mataramoe, de moeder. In Wajewa heeten ze Kabida kataroe nggede, Kanggaula woela male, en Mataramoe rara.

Omtrent het zwaard van Orion is men het zoowat overal eens, dat dit een varken is, dat door twee mannen tusschen zich in gedragen wordt, een voorstelling die men ook bij andere volken in Indië vindt. Daarom heet deze sterrengroep Malenggi wai, "een varken dragen»; in Wajewa Deito wawi. In Kambera spreekt men ook van drie sterren, maar ik heb mij niet kunnen vergewissen, of hiermee de gordel van Orion werd bedoeld. Ze heeten: Kandoenoe Kawiroe, Kandoenoe Tanda en Kandoenoe Ndaung; men ziet in die drie: vorst, edelman en slaaf.

Avond- en morgenster hebben overal namen, maar verder zijn geenerlei voorstellingen aan deze ster verbonden. In Lamboja heet de eerste Taro gadi, de tweede Ngoedoe ndama. In Wajewa: Kanggaoela en Ngindi dewa; deze laatste naam beteekent «de doodenziel meenemen», wat er op wijst, dat deze ster iets te maken heeft met het leven hiernamaals. In Kambera heet de morgenster Kandoenoe marai romoe, en de avondster: Kandoenoe hoe maling.

In Wajewa noemde men nog twee sterren: Ngooe pari, "rijstblok», en Ngooe watar, "stampblok voor mais». Wanneer de eerste niet te zien is, zal men geen rijst krijgen; verbergt de andere zich, dan mag niet op een maisoogst worden gerekend. Zoo zijn er nog drie andere sterren, waarvan twee vrij dicht bij elkaar staan, terwijl de derde verderaf verwijderd is. De laatste is wodo, de kat, die op de beide andere sterren loert, want dat zijn de malaoe bei, "wijfjesmuis», en de malaoe mane, "mannetjesmuis». Als de eerste onzichtbaar is, zegt men, dat zij in den grond is gekropen, en dit is een teeken, dat het gewas door muizen vernield zal worden, want de wijfjesmuis brengt jongen voort. Is daarentegen het mannetje onzichtbaar, dat is: in den grond gegaan, dan komt het er minder op aan, omdat een mannetje zich niet vermenigvuldigt.

Het Zevengesternte scheen men alleen in Lakoka en in Wajewa te kennen. In de eerste streek noemt men het Kawoworoe, in de tweede draagt het den naam van Marapoe. Aan zijn stand aan den hemel werd geenerlei beteekenis gehecht. 
Maan. In drie landschappen trof ik zegslieden aan, die mij de namen van de maan-dagen wisten op te noemen: Kambera, Lakoka en Lauli. De eerste dag der maan-maand heet nangita ja ahoe, «de hond ziet haar» (Kambera), djilik (Lakoka), naeta bangga, "de hond ziet haar» (Lauli). De tweede dag heet: nangita ja tau, "de mensch ziet haar» (Kambera), djilik (Lakoka), pera mata bawa, "halverwege de oogen» (Lauli). Dan worden in de eerste twee landschappen de dagen verder geteld met "de tweede, de derde», enz.. In Lauli heet de derde dag nog pera mata bodo, maar daarna worden de dagen ook geteld, tot aan eerste kwartier, didara. In Kambera en Lakoka heet eerste kwartier: "de zevende". In Lakoka telt men eenvoudig door tot volle maan, tamboloe: maar in Kambera hebben ook de drie dagen voor volle maan namen: heroeng akat, heroeng hămoe, tamboloe koedoe, en tamboloe, “vol». In Lauli: bali natara, nakawiroe, ngodo, "zitten»=volle maan. De dag na volle maan heet: kandjiding (Kambera), kahibit (Lakoka), moraso (Lauli). In Kambera noemt men nog laatste kwartier: natidoeng na woelang kandjiding, en den 25sten dag: napihil na woelang kandjiding, tot aan nangandi ja lodoe, "de zon heeft haar meegenomen $*=$ donkere maan.

Met deze maanstanden houdt men niet de minste rekening bij den landbouw, of wanneer men op reis wil gaan. Aan gunstige en origunstige dagen doet de Soembanees dus niet. Alleen als men een huis opzet, zal men dit nooit doen op nieuwe maan, merahoe.

In het Westen waar men zooveel aan rijstbouw doet, heeft men ook namen aan de maanden gegeven. Voor Lauli kon ik ze nauwkeurig opteekenen. Ze zijn: 1 . Woela pědoe; 2 . W. koba; 3. W. mangata; 4 . W. nale la mboja, de maand waarin de vischkuit aan het strand in Lamboja uitkomt (deze vischkuit wordt door de menschen met schepnetten gevangen); 5. W. nale wa noekaka, de maand waarin ditzelfde in Wanoekaka gebeurt; 6. W. nale moboe, de maand waarin de uitgeloopen vischkuit verrot is, wanneer die tijd dus voorbij is; 7 . W. to e a katete, de maand waarin de oebi rijp is; 8 . W. wo ea rara, de maand van de rijpe vruchten; 9. W. saroboe, oogstmaand; 10 . W. $\mathrm{m}$ a n a mo, de maand van het uittreden van de rijst (het dorschen met de voeten); 11 . W. kadêkara, de maand waarin de grond 
wordt omgewoeld om er de katela uit te halen; 12 . W. p édoe la mboja, de maand van het pědoe in Lamboja.

In Lamboja heeten de maanden: 1 Woelan pědoe; 2 . W. $\mathrm{kaba}$, waarin de rijst wordt uitgezaaid; 3 . W. mangata, de maand van het sawahbewerken; 4. W. njale, de maand van de uitgeloopen vischkuit; waarin de rijst wordt overgeplant; 5. W. njale gaoera, de maand van de uitgeloopen vischkuit in de streek Gaoera; 6. W. ng o e ra, de jonge maand; 7. W. to ea, de oude maand; 8 . W. maratana, de maand waarin aan de droge velden wordt gewerkt; 9. W. patoekoe, de maand waarin het feest van het vuistlaan plaats heeft; 10. Oogstmaand. De maanden na den oogst hebben blijkbaar geen naam.

In Wajewa telt men ook de maanden, maar daar geeft men ze geen namen. Wanneer de mais twee maanden oud is, begint men met de beddingen voor de zaairijst in orde te maken. De mais wordt geplant wanneer de regens doorkomen. Als de mangata-rara-boom van bladeren wisselt, is het de vijfde maand; als de mangata kaka dit doet, is het de zesde maand. Wanneer de redapa (dadap, Erythrina Indica) bloesems draagt is het tijd om met de droge velden te beginnen.

Voor Oost-Soemba geeft Bieger (Mededeelingen Ned. Zend. Gen. 34, 1890, bl. 16-17) het volgende: «Het jaar wordt verdeeld in 14 tijdperken: Kaw oeloer koedoe: begin van het katoenplukken; 2. Kawoeloer Bokoel; 3 . Waai Kamawa; 4. Beengi manoe; 5. Amoe laanda: aanleggen, schoonmaken der tuinen; 6 . Waandoe koedoe: laatste gedeelte van November, waarin men, na begin van regen, begint te planten; 7. Waandoe bokoel: tuinen gewied; 8. Siboe, en 9. Mengata, sterke regentijd, Februari; 10. Ngeli koedoe, de gierstongst; 11. Ngeli Bokoel, maisoogst; 12. Paloodoe, rijstoogst; 13. Langoe Paraingoe, feestmaand, Nieuwjaar; 14. Woelan toewa, katjangoogst».

De Woelan pedoe werd mij in Lauli en elders in West-Soemba aangegeven als de nieuwjaarsmaand, en de tijd van het groote ped o e-feest. Wat er dan gedaan wordt en waarvoor het dient, ben ik niet goed te weten kunnen komen, want de inlichtingen, die ik hierover heb kunnen krijgen, waren zeer onvolkomen. Van het oogenblik af dat de maan van de Woelan pedoe te zien is, wordt iederen nacht op gongs geslagen, en dansen mannen en vrouwen te zamen (nenggo). Iederen dag jaagt 
men op wilde varkens en herhaaldelijk worden kippen geslacht. In dien tijd mag geen buffel worden gedood. Is er een doode in die maand, dan wordt het lijk bewaard, en de begrafenis heeft pas plaats na afloop van dezen feesttijd. Men mag ook niet over den doode weenen, want dit zou ziekte en dood in het land brengen. Of de landbouw iets met dit feest heeft te maken, heb ik niet vast kunnen stellen. Men zei van niet maar het wordt toch gevierd tusschen den afloop van den oogst en het opnieuw bewerken der akkers. Ook al is de oogst mislukt, dan moet toch het feest gevierd worden, want liet men het na, dan zouden ziekten en misgewas daarvan het gevolg wezen.

Aan het einde van de maand heeft het eigenlijke feest plaats. Men noemde mij den naam selaroe; dan wordt er in den nacht gedanst (rendja). Jongens en meisjes mogen dan met elkaar doen wat ze willen. Den daarop volgenden dag heeft het kalango plaats; dit woord beteekent "gek». Tegen het aanbreken van den morgen zijn de mannen in één huis vereenigd, en de vrouwen in een ander, waar zij wachten op het opkomen van de zon. Zoodra deze boven de kim verschenen is, gaan een achttal mannen en even zooveel vrouwen naar beneden op het dorpsplein, nâtara, en naderen elkaar tot bij den dorpssteen, de watoe marapoe, die op deze ruimte geplaatst is. Ze loopen driemaal om den steen heen, en dan houdt iedere vrouw een man van achter bij de heupen vast. Zoo loopen die paren over het plein elkaar achterna: de man op één been voorthinkende, de vrouw van het eene op het andere springende. Als men elkaar ontmoet, aait, knijpt en duwt men elkaar. (We hebben hier misschien te denken aan het "schoppen", dat men in verschillende streken van Indië elkaar na het oogsten doet). Is de eene groep vermoeid, dan vangt een tweede met dit spel aan, en zoo gaat het den heelen dag door, totdat de zon is ondergegaan. Ten slotte gaat ook de radja naar beneden; hij plaatst zich aan de eene zijde van het plein, en een oude man gaat aan den anderen kant er van staan; dan loopen beiden om het plein heen, voortdurend met de linkerhand op de linkerdij slaande, en telkens roepende: Woi! Woi! bij wijze van uitdaging. Zijn ze zoo driemaal het plein rond geweest, dan komen ze bij den dorpssteen bij elkaar, en geven elkaar driemaal met de knie een lichten stoot. Daarna wordt het pleintje met een gordijn afgesloten, en mag men ge- 
durende drie dagen daar niet binnenkomen. Ook mag men in dien tijd niet naar zijn akker, zijn pinangtuin en andere aanplantingen gaan, want het gevolg daarvan zou wezen, dat men dan geen vruchten kreeg. Dit is alles wat ik van pedoe-feest ben te weten gekomen.

Bij dit feest doet een der ratoe's, Ratoe Dega, een lang gebed. De man was bereid mij dit gebed mede te deelen, en een groot gedeelte teekende ik er ook van op, maar zoolang de woorden niet genoegzaam verklaard kunnen worden, heeft het mededeelen weinig nut, en ik houd het hier dus terug. In dit gebed bezoekt de ratoe tal van plaatsen, te beginnen met Bali dokoe bara Dima, aan de overzijde van de zee; hij gaat ook naar den hemel en bezoekt verschillende plaatsen op het eiland Soemba. Met welk doel dit alles geschiedt, ben ik niet te weten gekomen.

Ook in Lamboja, waar de adat zeer veel overeenkomst heeft met die van Lauli, heeft men mij niet wijzer gemaakt. Men vertelde mij alleen, dat er bij die gelegenheid zeven dagen lang feest gevierd wordt, waarbij dag en nacht gezongen wordt. De zevende dag is het glanspunt; men noemt dezen wara wei; dan hebben allerlei spelen plaats, o.m. laat men paarden tegen elkaar rennen. «Dan mag men elkaar uitschelden en allerlei leelijke dingen zeggen», vertelde men mij. Den heelen dag worden gongs geslagen, en dansen de mannen (kodola), waarbij men elkaar niet vasthoudt. Den volgenden morgen begint men met het wieden van het onkruid op de akkers, het eerste werk dat gedaan wordt om ze voor de nieuwe beplanting toe te bereiden.

Landbouw. De grond der akkers wordt omgewerkt door middel van lange stokken, waarvan men in iedere hand één houdt. Met deze stokken stoot men een deel van den grond los van het overige, dan worden de stokken onder de afgesneden kluit gestoken, en wordt zij zoo, met de stokken als hefboomen, omgewenteld. Meestal doen eenige mannen dit werk gezamenlijk, naast elkaar staande, zoodat lange reepen aarde tegelijk kunnen worden omgelegd. Zooals reeds gezegd is, wordt sawahgrond omgewoeld door een kudde buffels, die men er in rond jaagt. Bij dit ronddrijven der buffels laat men de dieren in Lauli rechtsom, in Wanoekaka linksom loopen.

Op de natte velden wordt de rijst niet gezaaid, maar men 
maakt kweekbedden vanwaar de jonge plantjes naar den akker worden overgebracht. Op de droge velden maakt men met pootstokken gaten in den grond, en in ieder gat worden eenige korrels rijst gestort.

Wanneer in Taboendoeng met het bewerken van den grond begonnen wordt, worden eerst een varken en een kip geslacht bij het meertje Lapoeti, aan den oorsprong van de Kamberarivier, opdat er altijd voldoende water moge zijn om de velden te besproeien. Bij het herstellen van de waterleiding wordt ook een hoen geslacht, waarvan men het bloed in het water laat druipen. De sawah van den ratoe wordt het eerst omgewerkt. Zooals we reeds hebben gezien, is het de ratoe die de akkerwerkzaamheden regelt. Bij die gelegenheid worden een varken en een kip geslacht bij de plek, waar het water op de sawah komt. Daarna slacht ieder naar eigen goeddunken op zijn akker. Bij het overplanten van de rijst uit het kweekbed worden een kip, een varken en een paard gedood. Dan bidt de ratoe voor het gelukken van den oogst, en heeft er een groote maaltijd plaats.

In Anakala wordt de laka marapoe, de sawah der voorouders, het eerst onder handen genomen. Dit draagt den naam van $\mathrm{nkamba} \mathrm{manoe}$. Voor het zaaibed wordt een kip geslacht, bij het overplanten laten een geit, een varken of een buffel het leven. Wanneer de waterleiding hersteld wordt, wordt een varken gedood, welks bloed men echter niet in het water stort, men smeert het op den steen, katoda, die het veld bewaakt.

Wanneer in Lauli de rijst op het kweekbed wordt uitgezaaid, wordt een hoen geofferd en een gebed uitgesproken. Ditzelfde heeft ook plaats bij de bron, waarvan het water den akker bevloeit. Eerst na het uitzaaien begint men met het klaarmaken der akkers, waarbij de ratoe als gewoonlijk voorgaat. Bij het vertreden van den grond door de buffels helpt men elkaar, en voor die hulp geeft men elkaar te eten. Als de jonge rijstplantjes worden overgebracht, wordt eerst in huis geofferd en gebeden. Dan gaat een oude vrouw met wat rijstplantjes, katoen, gestampte rijst, en wat vruchtvleesch van de kokosnoot naar den akker, daar waar het water er op komt, en waar de steen (hier marapoe katoera genoemd) staat, die voor het heele sawahcomplex instaat. Daar plant zij de zaailingen, en werpt het andere dat ze meegebracht heeft, in het water. Eerst daarna gaan allen aan het overplanten: mannen en jongens halen de 
plantjes van het kweekbed, vrouwen en meisjes steken ze in den grond. Men plant van boven naar beneden, d.i. van af het punt, waar het water op den akker komt, en volgt verder den stroom. In Lamboja gaat het toe als in Lauli. Daar heet het kweekbed pinja kaleba. Als de plantjes een maand oud zijn, worden ze overgebracht, bij welke gelegenheid gewoonlijk een varken of een buffel wordt geslacht. In het eigenlijke Lamboja begint de radja van Sodan met het werk; in beneden-Lamboja is dit de Oemboe Waleha, Heer van Waleha; in Patiala zijn het weer andere voormannen, die het akkerwerk leiden.

Wanneer in Wajewa de rijst op het kweekbed wordt uitgezaaid, wordt er geofferd en gebeden, maar er wordt ook een peperhuis van opgerold kokosblad gemaakt, dat aan den kant van het kweekbed wordt geplaatst; er wordt niets in gedaan, maar de handeling moet toch tot het welslagen van de rijst bijdragen. Het vertreden van den grond door de buffels heet hier karêkata; daarbij wordt een beest geslacht en een gebed uitgesproken. Dit geschiedt ook bij het overplanten. Wanneer de rijst drie maanden oud is, heeft het pedoe tana plaats; wat dit eigenlijk is, ben ik niet te weten kunnen komen; het lijkt op een soort taboe-tijd, waarin onder meer niemand op zijn akker mag gaan wieden.

Tegen plagen van muizen, rijstdiefjes (manginoe), en insekten, die het gewas vernielen, weet men niet anders te doen dan te bidden en te offeren bij den steen die den akker heet te beschermen.

Wanneer de rijst vrucht zet, en deze aan het uitkomen is, is het een tijd van veel spanning, en daarom moet men zich dan bijzonder in acht nemen. In Kambera wordt er in het dorp geofferd en gebeden, geslacht en gekookt. Dit offer, waarbij nog goudschilfers, kralen en een mes worden gevoega, wordt dan in twee manden gedaan. 's Avonds als het donker is geworden, brengen twee mannen die manden weg. Ze moeten daarbij heel stil te werk gaan, en niet praten. Ze brengen die manden naar de katoda pameling, een steen, die onder een grooten boom staat; de offers daar gebracht zijn voor Marapoe tana, de heer der aarde. Wanneer de manden bij dien steen zijn neergezet, gaan de beide mannen eten en bidden, waarbij zij aan Marapoe om veel rijst vragen. $Z$ ijn ze hiermee gereed, dan gaat eerst de eene weg, en een poos daarna de tweede. Dan komt de eerste terug en zegt: "Wie heeft deze spijs hier vergeten? Dat is een 
voordeeltje». Dan dragen beiden de manden weer naar het dorp terug.

In Taboendoeng mogen geen menschen van andere plaatsen naar den akker gaan, waar de rijst al heeft vrucht gezet. Buffels mogen er niet langs geleid worden; menstrueerende vrouwen moeten zich verre van daar houden; kalk, pas gesneden bamboe en alang-alang mogen er niet langs gevoerd worden. Het gezin van den eigenaar mag geen bittere dingen eten. Dit alles moet worden volgehouden tot de oogst is afgeloopen.

In Anakala en Lauli mogen kabaroe (Jav. wa roe, Hibiscus tiliaceus L.) en padang (pandanus) niet langs zulk een veld gebracht worden; de aren zouden ten gevolge van zoo iets loos worden. De rijst wordt dan met kokoswater besprenkeld, een gebruik dat over geheel Soemba in acht genomen wordt. Zoo wordt ook algemeen bij den akkersteen geofferd, als de vrucht uitkomt.

In Wajewa mag men, als de vrucht der rijst is uitgekomen, geen pandan-bladeren (die voor manden en matten gebruikt worden) meer gaan halen; men mag niet gaan visschen en geen garnalen en paling vangen totdat de vrucht geheel gerijpt is. In dien tijd mogen kalio-bladeren, waarmee geweven doeken zwart gemaakt worden, en bladeren van de o eka (W. S.), hoeka (O. S.) (Gnetum Gnemon) daar gebracht worden; men mag geen hoeden van pisangblad gemaakt gebruiken; er mag op den akker geen boombast tot kleedingstof worden geklopt; apen en wilde varkens mogen daar niet geroosterd worden; visch, garnalen en paling mogen er niet gebracht worden. Roode rijst wordt gekauwd, en dit kauwsel wordt over het gewas gespuwd; kokosvleesch wordt gekauwd, en het sap aan de rijststengels gesmeerd; een bruine haan wordt op den akkersteen geofferd.

Laat ons thans nagaan de gebruiken, die bij den oogst in acht genomen worden. Voordat men met het plukken of afstroopen (gesneden wordt ze zelden) van de rijst begint, wordt allereerst over heel Soemba in de huizen gebeden en geofferd, en uit de ingewanden der geslachte dieren wordt opgemaakt of de tijd voor dit werk gunstig is. Hier en daar wordt dit ook gedaan door wichelen met de lans. Overal heerscht ook het verbod om coitus uit te oefenen, want daardoor zouden de menschen ziek worden, en men zou niet veel rijst krijgen; alleen de gewettigde huwelijksgemeenschap van een getrouwd paar kan hier geen kwaad. 
Wanneer men in Kambera met den rijstpluk aanvangt, geeft men op de plek waar men begint sirih aan de rijst; en als men tegen het vallen van den avond ophoudt, doet men op die plaats weer hetzelfde. Dit wordt iederen dag bij het begin en het einde van het werk herhaald, zoolang als het oogsten duurt.

In Kambera wordt alle rijst voor de tuinhut verzameld en daarna met de voeten getreden; manden worden om die plek heen gezet, die langzamerhand gevuld worden; een man bidt er bij, en dit houdt hij zoolang vol totdat alle manden vol zijn. Als men het kan doen, wordt bij het treden van de rijst een varken geslacht, en als het werk is afgeloopen, wordt wat van de rijst, een weinig aarde van den akker en het kinnebak van het geslachte varken naar het marapoe-huis in het stamdorp gebracht. Voordat dit gebeurt, geeft men hiervan eerst kennis aan de deur, de stijlen en aan de andere onderdeelen van het tuinhuis.

In Taboendoeng wordt eerst de rijst van het veld van den ratoe gehaald. Nadat er gebeden is, gaan tien menschen oogsten; zij plukken vijf manden vol; deze rijst wordt gedroogd, gestampt en gekookt; daarvan geeft men aan de marapoe te eten, en verder maakt men er een algemeenen maaltijd van. Eerst na afloop hiervan mogen alle menschen de rijst gaan binnenhalen. De radja van Taboendoeng vertelde mij ook, dat soms bij het begin van den oogst een oudere man en vrouw worden uitgezocht om als een soort verpersoonlijking van het gewas dienst te doen. Die lieden worden door het orakelsnoer aangewezen. De man wordt fraai aangekleed met oorhangers, een mooien hoofddoek, terwijl de vrouw behalve fraaie kleeren ook ivoren armbanden en kostbare kralen om den hals krijgt. Deze vrouw heet pararatoe, "andere helft van den ratoes. Zij wordt uit de meer aanzienlijke vrouwen genomen. Als zij water gaat halen, wordt zij altijd door iemand vergezeld; ze wordt steeds bediend en er moet worden gezorgd, dat zij altijd lekker te eten heeft. De man, die de vervanger van den ratoe is, en de pararatoe oogsten ook mee. Tot belooning krijgt de vrouw later een sarong en wat rijst; de man ontvangt ook een doek en wat rijst. De overige lieden die meegeholpen hebben met oogsten, krijgen alleen wat rijst.

Zoolang het oogsten nog niet is afgeloopen, mag men zich niet ergens anders heen begeven; men mag niet den grond 
omwerken. Van de pas geoogste rijst mag niets worden gegeten; dit wordt als diefstal beschouwd. Slechts rijst en mais van den vorigen oogst worden gegeten. Tijdens den oogst mogen geen oebisoorten worden genuttigd; om deze vruchten te halen, zou men den grond moeten omwerken, en dit is verboden. Aan de Marapoe geeft men te eten: rijst, hili (Colocasia), la ji a (gember), rupsen die in de bamboe gevonden worden, en een vischje.

Bij het plukken in Taboendoeng begint men steeds aan de Oostzijde van het veld, en beweegt zich naar het Westen. Aan den Westkant oogst men niet alles af, maar men laat een deel van de vrucht staan, ongeveer de hoeveelheid van twee manden vol. Dit is voor de dooden bestemd. Leden van het gezin van den eigenaar mogen deze rijst niet nemen, maar aan andere lieden staat het vrij dit te doen. Bij het begin van den pluk heeft men in het midden van den akker een grooten bos rijst gesneden. Dit is de in a o e hoe, de rijstmoeder; deze laat men op de plek waar ze gesneden is staan; zij moet voorkomen, dat de overige rijst wegloopt. De geoogste rijst wordt op een hoop te zamen gebracht op het veld, om daarna uitgetreden te worden (met de voeten gedorscht).

Te Maka menggit in Lewa maakt men niet zooveel omslag; wanneer daar aan Marapoe geofferd en gebeden is, wordt het heele veld in eens afgeoogst. Daar de droge velden (men heeft hier geen sawahs) in de dalen zijn aangelegd, begint men te oogsten aan het benedeneinde van het veld, den zoogenaamden staart, en beweegt zich zoo naar het hooger gelegen deel, den kop. Ook hier wordt van de nieuwe rijst een mand vol aan de marapoe opgedragen. Die rijst wordt daarna gestampt, gekookt en opgegeten; maar overigens mag van den nieuwen oogst voorloopig niets gebruikt worden. Al die geplukte rijst wordt op het veld zelf uitgetreden, en daarna heeft een «bidfeest» plaats.

In Lakoka begint de ratoe met oogsten, maar daarna doet ieder dit werk naar dat het uitvalt. De geoogste rijst gaat in manden, die weer op een mat worden uitgestort. Wanneer het heele veld is afgeoogst, wordt de rijst getreden. Dit werk wordt door mannen gedaan, en geenerlei voorzorgsmaatregel behoeft daarbij in acht genomen te worden. In Lakoka mag men dadelijk van de nieuwe rijst eten, en er van verkoopen aan stamgenooten; aan vreemden echter nog niet.

Aan den vooravond van den dag, waarop men in Anakala Dl. 78. 
met oogsten zal beginnen, zet men een wairi witoe bij den algemeenen akkersteen, de katoda kabondoekoe, waarvan boven sprake is geweest. De wairi witoe is een stok, waaraan alang-alang (witoe) gebonden is. Wanneer dat teeken is opgericht, mogen daar geen menschen van andere plaatsen komen. Den volgenden morgen slacht men er een kip en een varken. Dan gaan allen naar den akker der voorouders (laka marapoe), de ratoe snijdt eerst wat halmen, en daarna gaat hij bij den akkersteen zitten, overdekt zich het hoofd met een doek, en bidt. Al de geoogste rijst wordt daar bij hem gebracht. Bij het oogsten (hier wordt de rijst gesneden) beweegt men zich van het Zuiden naar het Noorden. Dit mag niet van Oost naar West of andersom gebeuren. Van de rijst van dezen akker der voorvaderen krijgt de ratoe een mand vol. $B i j$ het binnenhalen van de vrucht op de andere velden worden geenerlei formaliteiten in acht genomen.

Wanneer in Lauli het oogsten zal beginnen, gaat van ieder gezin een vrouw wat rijst snijden op haar sawah. Al die rijst wordt voor ieder huis samengevoegd tot een grooten bos, ia rende, "een bos» genaamd. Iedere woning heeft dus zoo'n reuzenbos. Deze wordt op de leli geplaatst, de offerplank om den hoofdpaal van het huis. Dan wordt daar drie dagen lang gebeden en geofferd, waarbij een kip of een varken wordt geslạcht. $\mathrm{Na}$ afloop van dien tijd mag ieder de rijst van zijn veld gaan oogsten, "van beneden naar boven" gaande, d.i. steeds van de van den akkersteen verst verwijderde zijde van het veld, naar dien steen toe zich bewegende. Hier wordt de rijst weer niet gesneden, maar met de hand afgestroopt of geplukt, wat op Soemba regel is.

Op de pas genoemde offerplank (die in Lauli labe heet) bevinden zich ook steentjes, die de afgestorvenen vertegenwoordigen. Deze steentjes worden hier kora, "slijpsteen» genoemd. Ze worden met elkaar ingepakt en in een mandje gelegd, samen met een mes. Zoolang het oogsten duurt, neemt men iederen morgen dat mandje mee naar den akker, en iederen avond brengt men het weer naar huis. De beteekenis er van is duidelijk: de dooden moeten ook aandeel hebben aan dit werk, want zij hebben tot het welslagen er van meegewerkt.

Wanneer in Wajewa de tijd van het oogsten daar is, wordt een offer aan Marapoe gebracht, en deze wordt aangeroepen 
om naar beneden te komen. Door middel van de lans tracht men te weten te komen of Marapoe gekomen is: wanneer de duim van rechterhand bij het gespreid zijn der armen langs de lans, den wand of den paal bereikt, is dit een bewijs, dat de geest er is; dit is dan tevens een teeken, dat met het oogsten een begin kan worden gemaakt. Den volgenden morgen gaat een man zeven rijsthalmen snijden; hij legt ze in een klein mandje, kolaka geheeten. Dit mandje brengt hij in de tuinhut, en plaatst het op een rekje, dat daar in een der hoeken van de hut is aangebracht. Dit rekje heet rambe pari; daarbij worden nog wat gestampte rijst, sirih-pinang, en een deel van de lever van het bij deze gelegenheid geslachte offerdier (hoen of varken) gevoegd. Den volgenden dag gaan allen oogsten, en 's avonds wordt een mandje (kaweda) vol met de pas geplukte vrucht bij het eerst genoemde korfje, de kolaka, geplaatst.

Als men oogst, moet men zich daarbij op zulk een wijze bewegen, dat men de mata pamba, den akkersteen, steeds aan de rechterhand heeft; de planten, die in de buurt van dien steen staan, worden het laatst van alle afgestroopt. Alle rijst wordt getreden om de korrels van de halmen te scheiden. Alleen sommige soorten, bekend onder den naam van pari kalada, "groote rijst", worden gesneden, en in bossen gebonden, omdat de korrel er van niet gemakkelijk loslaat.

Ook in Laura wordt de oogst aangevangen met gebed en offer in het woonhuis. Begint men te plukken, dan wordt eerst een bosje rijst op den mata pamba gelegd, voor den mangoe tana, "eigenaar van den grond»; ook wordt zulk een bosje in de tuinhut gedeponeerd; en eerst wanneer alle rijst getreden (gedorscht) is, wordt ook een bosje aren voor de huismarapoe in het dak boven de trap gestoken. Ook hier moet men zorgen bij het oogsten den akkersteen altijd aan zijn rechterzijde te hebben.

In sommige landschappen treft men rijstschuurtjes aan, zooals in Taboendoeng, Lakoka, Anakala, hier en daar in Wajewa. In Anakala worden die schuurtjes oema ari, genoemd van oema= huis, en a ri=jongere broer; dus huis van den tweeden rang in vergelijking met het woonhuis. Elders vindt men zulke schuurtjes niet, zooals in Lewa en Lauli. In laatstgenoemde streek is het zelfs verboden ze er op na te houden, omdat die schuurtjes in vorm zooveel gelijken op de hutten die men voor 
den marapoe bouwt. Hetzij de rijst in schuren, hetzij ze in het woonhuis wordt opgeborgen, men bewaart ze altijd in manden, dandakoe genaamd, soms ook dendakoe, alleen in Wajewa kapatela. Deze manden zijn gewoonlijk van de bast van den $\mathrm{kab}$ a roe-boom (Hibiscus tiliaceus L.) of van de hoea, soea, of o eka-boom (Gnetum Gnemon). Zeldzamer zijn ze van rotan. In Taboendoeng wordt eerst de in a ohoe, de rijstmoeder, binnengebracht en opgeborgen. Onder in het vat legt men op heel Soemba eerst wat goud- en zilverschilfers en sirih-pinang, opdat de rijst niet spoedig oprake. Het vullen van de vaten geschiedt door een man. In Anakala moet deze fraai zijn uitgedost. Hij krijgt voor dit werk geen belooning, maar wanneer de oogst goed is uitgevallen, slacht de huisheer een jongen buffel of een varken. Elders behoeft deze man niet bijzonder mooi aangekleed te zijn.

Omtrent de bestemming van den nieuwen oogst worden weer twee verschillende gedragslijnen gevolgd. In sommige streken, zooals Lewa, Anakala, een deel van Wajewa, mag voorloopig niets van den nieuwen oogst worden gebruikt. De vaten blijven dicht tot aan het doorkomen van de regens. Dan wordt er eerst uitgehaald de rijst, die moet dienen om geplant te worden, en daarna pas mag men van het overige eten. In Wajewa wordt wel eens een hoen of een varken geslacht als een zeer groot rijstvat wordt geopend.

In andere streken weer, zooals in Taboendoeng, Lakoka, Lauli, mag men dadelijk van die nieuwe rijst gebruiken. In Lauli wordt echter een voorbehoud gemaakt: daar mogen lieden die niet tot de Lauliërs behooren, die rijst nog niet eten. Wil iemand een vreemdeling toch te eten geven, dan ruilt hij de rijst, die hij aan den vreemde te eten wil geven, met rijst van een lid van een ander geslacht (kabisoe). Deze wordt dan klaargemaakt en aan den gast voorgezet. In Lauli moet ook steeds dezelfde vrouw of dezelfde man rijst uit de vaten halen.

Wanneer alle rijst is binnengehaald, hebben allerlei feestelijkheden plaats. In Taboendoeng heet dit feest pamangoe katoda, "offermaal van de katoda". Dit moet afgeloopen wezen, voordat men van de nieuwe rijst mag eten en verkoopen. Zoo moet ook in Lamboja eerst de plechtigheid van het woelan kaba pari beroe (nieuwe rijst) afgeloopen zijn, voordat over de rijst mag worden beschikt; bij dat feest wordt ook een offer 
aan den marapoe aangeboden. Zulk een feestelijkheid aan het einde van den oogst zal overal op Soemba wel p!aats hebben, al heeft men mij dat niet altijd verteld. Als de oogst goed gelukt is, heerscht er vooral in West Soemba, het rijstland, groote vroolijkheid. 's Avonds worden de gongs naar den akker gebracht, en men vermaakt zich met elkaar te schoppen (Lauli, Lamboja, Laura, Memboro). Vooral bij lichte maan ontstaan er soms gevechten, waarbij wel eens bloed vloeit; maar kwalijk nemen mag men dit niet. Kinderen en ook ouderen loopen dan uren lang zingende over de afgeoogste akkers. Dit heet in Lauli: goko geile.

Paling. Boven is al verteld dat in Taboendoeng een meertje is, Lapoeti genaamd, de oorsprong van de Kambera-rivier. Daar wordt bij het begin van de bewerking der rijstvelden en na afloop van den oogst geofferd aan de geesten van die plek; dezen zorgen voor regen, dus voor de bevloeiing der akkers. Dien geest denkt men zich verpersoonlijkt in de in dat meer levende palingen, to en a. Zoo heeft men ook in Anakala een voor heilig gehouden water te Sotoe, waar de bronnen gevonden worden van het water dat naar Laura stroomt. Ook hier wordt geregeld gebeden en geofferd ten behoeve van den landbouw. Wanneer een vrouw een kind wenscht te hebben, wordt van dat water gehaald, waarmee zij zich dan baadt; dan denkt zij dat haar wensch in vervulling zal gaan. Ook als andere geneeswijzen geen baat hebben gevonden, gaat men wel als laatste redmiddel voor een ernstig kranke, water van Sotoe halen om hem daarmee te baden. Maar in het algemeen kan men zeggen, dat alle bronnen van eenig belang door den Soembanees worden ontzien, en dat de daarin levende palingen nimmer door hem zullen worden gevangen en gegeten.

De Soembanees is een groot liefhebber van paling. Overal wordt hij gegeten; gekookt, geroosterd, gerookt. Ik heb slechts één geval gevonden, dat aan totemisme doet denken. De menschen van Pela namelijk, die oorspronkelijk uit Wajewa af komstig zijn, eten geen paling, omdat zij beweren, dat een paling hun grootmoeder is geweest. De palingen in bovengenoemde bronnen worden ratoe genoemd. Met dienzelfden naam worden bijzonder groote palingen in niet verboden gebieden aangeduid. Als men zulk een reuzenpaling heeft gevangen, is men er eenigszins huiverig voor, maar dit neemt niet weg, dat men hem toch 
eet. Men moet daarbij echter eenige voorzorgsmaatregelen nemen. Wanneer men bijvoorbeeld in Bolobokat zulk een dier heeft thuisgebracht, wordt eerst een varken of een geit geslacht, en er wordt tot den marapoe gebeden; uit de lever van het geslachte dier wordt dan opgemaakt, of er geen bezwaren bestaan tegen het opeten van de vangst. Eerst daarna wordt het vleesch verdeeld.

Aardbeving. In Memboro vertelt men dat de aarde aan een koord (navelstreng) hangt. Daaraan knaagt nu en dan een muis met de bedoeling om 't koord door te bijten, en de aarde te laten vallen. Maar dan komt een kat en jaagt haar weg. Door dit wegjagen schudt de aarde.

In Kambera heeft men dezelfde voorstelling; alleen wordt daar de aardbeving veroorzaakt door het knagen van de muis. Men slaat op blikken, en maakt op allerlei wijzen geraas om de kat wakker te maken, opdat zij de muis zal verjagen.

Een ander verhaal in het Westen zegt, dat Ama Kalada, de hemelheer, een geest losgelaten heeft, die overal verderf verspreidde. Deze verdelger reed op een paard met twee koppen, en veroorzaakte overal ziekte door met zijne schaar te knippen. Toen Ama Kalada vond dat het genoeg was, zei hij tot den verdelger: "Tot hiertoe!» Maar de geest bleef voortgaan met zijn dood en verderf brengend werk. Toen dekte Ama Kalada hem toe met zijn hoed, en deze werd een groote berg, waarin de geest tot op den huidigen dag gevangen zit. Telkens probeert hij om van onder den berg uit te komen, en bij zijn pogingen daartoe doet hij de aarde beven. Dan roept men: Si anggama, *Hier zijn wij!»

Nadat ik bovenstaande aanteekeningen had uitgewerkt, voelde ik levendig het gemis van nadere gegevens omtrent het landschap Kodi, waardoor het niet mogelijk was een beeld te krijgen van de maatschappij der Soembaneezen over het geheele eiland. Om dit gemis zooveel mogelijk aan te vullen, stelde ik eene lijst van vragen op, en zond deze aan den Heer L. Vriesman, 1e luitenant en Gezaghebber van Noordwest-Soemba, onder welke onderafdeeling de beide Kodi's ressorteeren. (Naar ik vernomen heb, zijn de onderafdeelingen Noordwest- en Zuidwest-Soemba thans bij elkaar gevoegd onder den naam van West-Soemba.) 
Met groote welwillendheid heeft de Heer Vriesman aan mijn verzoek voldaan, waarvoor ik hem zeer dankbaar ben. Door de gezonden antwoorden kan ik hieronder een overzicht geven van het huwelijksstelsel in de beide landschapjes Kodi.

Zooals ik vroeger reeds heb medegedeeld, worden de bewoners van de genoemde streek in families verdeeld, die niet als in het overige Soemba kabisoe worden genoemd, maar die hier den naam dragen van wala. (Ik hoorde dit woord indertijd uitspreken als wěla, maar de Heer Vriesman schrijft wala, en aangezien hij langer met deze lieden in aanraking geweest is, moet ik deze schrijfwijze voor de juiste houden.) Men gaf den Heer Vriesman de namen op van $49 \mathrm{wala}$, en wel de volgende:

Wala Uawi Bokoel, wala Loge, w. Hedo, w. Ganggar, w. Gawi Boela, w. Bero, w. Pata, w. Atoer, w. Pidja, w. Bila, w. Watoe, w. Borota, w. Rowa, w. Lele, w. Biri, 'w. Toebe, w. Karaboe, w. Ende, w. Kapadoe, w. Rangga Ganoe, w. Tana Maringe, w. Koela, w. Peino, w. Njoba, w. Wonda, w. Djale, w. Hatti, w. Dinga Kedoe, w. Pati Kere, w. Pati Anga, w. Langge, w. Lando, w. Tenggo, w. Longgo, w. Mada, w. Soke, w. Bomba, w. Tala Doeka, w. Raoe Rapoe, w. Memborongo, w. Dato, w. Katidjaho, w. Riti, w. Katakoe, w. Hare, w. Lere Karara, w. Kaitjo, w. Madaloeko, w. Malago.

Van deze wala zijn de eerstgenoemde zes de voornaamste, waarschijnlijk omdat zij de oudste families vertegenwoordigen. Het is voor een lid der overige wala eene eer om met een meisje uit een dier eerste zes families te trouwen. Leden van dezelfde wala mogen niet met elkaar huwen.

Iedere wala bewoont niet eene bepaalde streek, maar de leden van de verschillende families leven dooreen vermengd in de landschappen Kodi Bokoel en Kodi Bangedo en in de daarbij gevoegde landschapjes Kodi Belagar, Nggaro en Rara. In plaats van hunne afkomst van een man af te leiden, zooals in het overige Soemba het geval is, voeren de lieden in Kodi hunne afstamming terug tot vrouwen. Hiermee in overeenstemming is, dat een kind behoort tot de wala van de moeder.

Men zou nu verwachten in Kodi al die gebruiken te zullen vinden, die een gevolg zijn van het moederrechtelijk stelsel, maar het tegendeel is waar. Het instituut van de bruidsschat bestaat hier in volle kracht. De bruidegom moet hem voldoen aan den vader van het meisje, of aan het familielid (broer, oom, 
neef), dat het meisje verzorgt. Is de man niet in staat een bruidsschat te betalen, en neemt de familie van de vrouw daarmede genoegen, dan komt hij bij den vader van zijne vrouw inwonen, en werkt voor hem, zoolang tot hij in staat is den bruidsschat te voldoen. Zoolang dit niet gebeurd is, mag hij zijne vrouw niet naar zijn eigen woonplaats meenemen. Dit wordt hem alleen wel eens toegestaan, wanneer nog maar een klein deel aan het bedrag ontbreekt, maar dan is hij ook verplicht dit ontbrekende zoo spoedig mogelijk aan te vullen. De man kan niet in de plaats van den bruidsschat een zijner kinderen aan zijne schoonouders afstaan, een gewoonte die we bijvoorbeeld op Timor vinden.

De bruidsschat, wali genaamd, bestaat uit buffels, paarden, gouden oorhangers (mamoeli), lansen en hakmessen. Wanneer de man goed in zijn vee en have zit, voegt hij van al de genoemde beesten en voorwerpen een of meer aan den bruidsschat toe. Het aantal dieren dat gegeven wordt wisselt van een tot vijftig; de oorhangers van een tot tien. Voor de lansen en hakmessen worden geen getallen genoemd. Het is de vader of verzorger van de bruid, die de grootte van den bruidsschat bepaalt. Dikwijls wordt deze sterk opgedreven om er mee te kunnen prọken tegenover zijne stamgenooten.

Bij het vaststellen van de grootte van den bruidsschat moet de vader of verzorger van het meisje echter wel bedenken, dat hij eveneens aan de familie van den bruidegom een geschenk heeft te geven, en ofschoon deze genoegen moet nemen met alles wat gegeven wordt, eischt de adat toch, dat de tegenprestatie, die den naam draagt van lipoko, wat grootte betreft in overeenstemming is met den geëischten bruidsschat. Deze li poko bestaat uit buffels, paarden, varkens, ivoren armbanden, beenringen en katoenen goederen (hing gi). Het spreekt vanzelf, dat eerst wanneer de wali (bruidsschat) betaald is, de lipoko (tegengeschenk) wordt overgegeven.

Waar het kind de w a la zijner moeder volgt, is het begrijpelijk, dat kinderen van twee zusters niet met elkaar mogen huwen. Maar ook de kinderen van twee broers, wanneer zij door hunne moeders tot twee verschillende families behooren, mogen zich niet met elkaar verbinden. Terwijl kinderen van een broer en eene zuster in het overige Soemba onder bepaalde omstandigheden (zoon van de zuster met dochter van den broer) met 
elkaar in het huwelijk mogen treden, zijn zulke verbintenissen in Kodi geheel buitengesloten.

Het is vroeger wel voorgekomen, dat iemand de zuster zijner echtgenoote als tweede vrouw nam. Dit mocht dan alleen gebeuren, wanneer de echtgenoote daartoe hare toestemming had gegeven. De man had voor zijne tweede vrouw evenzeer een bruidsschat te betalen. Men schijnt zulk een dubbel huwelijk van twee zusters met denzelfden man toch niet graag te zien, want volgens het getuigenis was zoo iets in langen tijd niet meer voorgekomen.

Een man mag huwen met de zuster van zijns broers vrouw of met de zuster van zijns zusters man.

Een huwelijk met zijne schoonmoeder na den dood zijner vrouw, of met de weduwe zijns vaders, die niet zijne eigen moeder is, of een huwelijk met de zuster van vader of moeder, is geheel buitengesloten. Had in den tijd voordat het Gouvernement op Soemba kwam huwelijksgemeenschap tusschen genoemde personen plaats gehad, en was dit bekend geworden, dan werden de schuldigen met de lans of het hakmes gedood.

Een huwelijk met de zuster van zijn schoonvader is geoorloofd, maar niet met de zuster van zijne schoonmoeder.

Wanneer een man een meisje wil vragen om zijne vrouw te worden, deelt hij dezen wensch aan zijn vader mede. Deze of een ander persoon, die daartoe wordt afgezonden, brengt dan het aanzoek aan den vader van het meisje over. De jonge man doet dit nooit zelf. Is het aanzoek door een ander dan den eigen vader overgebracht, dan krijgt de huwelijksmakelaar, wanneer zijne pogingen met gunstig gevolg zijn bekroond, en de echt gesloten wordt, een buffel of een paard, en bovendien nog een gouden oorhanger tot belooning; bij aanzienlijken krijgt hij ook wel eens twee van de genoemde dieren voor zijne moeite.

Het eerste wat gedaan wordt wanneer in het huwelijk is toegestemd, is de grootte van den bruidsschat vast te stellen. Is dit geschied dan wordt ook de dag bepaald, waarop de familieleden van bruid en bruidegom met de genoodigden te zamen zullen komen om tegenwoordig te zijn bij de overgave van den bruidsschat (wali), en het tegengeschenk (lipoko).

Bij deze samenkomst zitten de bloedverwanten en vrienden van den bruidegom in het eene gedeelte van de voorgalerij der woning van de bruidsouders, terwijl de familieleden en kennissen 
van de bruid in het andere gedeelte hebben plaats genomen. Gewoonlijk is het gezelschap van beide kanten zoo groot, dat er in de galerij niet voor allen ruimte is. In dat geval moet een deel der gasten genoegen nemen met een plaats buiten op het woonerf.

Het gesprek dat tusschen beide partijen gehouden wordt, heeft steeds plaats door bemiddeling van een tusschenpersoon, die tusschen de twee groepen in zit. Het is niet noodig, dat deze man een bloedverwant van den bruidegom is; de laatste kiest daartoe iemand uit, die goed ter tale en gevat is. Wat door de eene partij gezegd wordt, wordt door hem aan de andere overgebracht.

De familie van den bruidegom begint de onderhandeling met te vertellen hoeveel beesten en goederen, die als bruidsschat bestemd zijn, verzameld en hier gebracht zijn. Wanneer de opgegeven getallen in overeenstemming zijn met de grootte van den bruidsschat, zooals deze is afgesproken, zegt de familie van de bruid, dat de zaak in orde is, en ze deelt tevens mede, dat het tegengeschenk (lipoko) gereed ligt. De tusschenpersoon bedient zich van allerlei beeldspraak en kwinkslagen bij het overbrengen van hetgeen gezegd wordt, om aan de zaak een gezellig en vroolijk karakter te geven.

Is de onderhandeling afgeloopen, dan wordt de bruid bij den bruidegom gebracht. Ze gaan vlak naast elkaar op een mat zitten. De bruid biedt haar aanstaanden man sirih-pinang en tabak aan, waarna de man ditzelfde bij zijne bruid doet. Ze zeggen niets tot elkaar en blijven stil naast elkaar zitten. De familieleden en vrienden mengen zich dooreen.

De vader van de bruid laat nu een varken slachten, soms ook een buffel of een paard, en zoo doet ook de vader van den bruidegom. Het vleesch wordt tusschen beide partijen verruild, zoodat de familie van de vrouw het vleesch eet, dat door de verwanten van den man geleverd is en omgekeerd, een verzoeningsmaal dus. Het vleesch wordt gebraden. Van de ingewanden der geslachte dieren wordt een deel te zamen met wat rijst aan den marapoe (geest) van het dorp geofferd. Dit is een steen, die van 20 tot $40 \mathrm{cM}$. boven den grond uitsteekt, en die omringd is door enkele lagere en platte steenen.

Het feestmaal, dat vervolgens gehouden wordt, bestaat uit rijst en vleesch van de geslachte dieren. Bij deze gelegenheid 
eten bruidegom en bruid vaak uit hetzelfde bord. Is na afloop van den maaltijd de sirih-pinang rondgediend, dan is de plechtigheid afgeloopen; de gasten keeren allen naar huis terug en de bruidegom voert zijne bruid naar zijne eigen woning.

Schaking komt ook voor. Dit kan op tweeërlei wijzen plaats hebben: In het eene geval geeft de man aan de huisgenooten van het meisje kennis van zijn voornemen om haar te schaken; hij geeft dan ook de plaats op, waar hij haar heen zal brengen. Alleen de ouders van het meisje worden van dit plan onkundig gelaten. Daar de huisgenooten er van weten, is de vader van het meisje dadelijk na het gebeurde in staat om den schaker op te zoeken. Bij de ontmoeting wordt aanstonds over den bruidsschat onderhandeld. Loopt dit goed af, dan kan de man het meisje als zijne vrouw bij zich houden. Kunnen de vader van het meisje en de schaker het echter over deze aangelegenheid niet eens worden, dan neemt de vader zijne dochter weer mee naar huis. Behalve den bedongen bruidsschat moet de schaker nog een of twee buffels boete betalen.

In het tweede geval geeft de man aan niemand kennis van zijn voornemen om het meisje te schaken. Van eene goede gelegenheid dat zij alleen water of hout haalt, makt de man gebruik om haar mee te nemen. Thuis gekomen slaat hij op de gong, zoodat de bloedverwanten van het ontvoerde meisje dadelijk weten, waar zij te vinden is. Haar vader, of een andere vertegenwoordiger der familie begeeft zich dan daarheen, en de onderhandelingen beginnen zooals in het eerste geval is beschreven. Gewoonlijk gaat de man tot schaken van het meisje over, wanneer hij vermoedt, dat zijn aanzoek op tegenkanting bij haar familie zal stuiten.

Wanneer de getrouwde vrouw van haar man wegloopt, of van hem wil scheiden, moet de bruidsschat (wali) worden teruggegeven, terwijl de familie van den man het tegengeschenk (lipoko), dat door de verwanten van de vrouw is gegeven, kan behouden. Verstoot de man zijne vrouw, of loopt hij van haar weg, dan worden noch bruidsschat, noch tegengeschenk gerestitueerd. Soms heeft scheiding plaats met wederzijdsch goedvinden. In zulk een geval worden òf bruidsschat en tegengeschenk terug gegeven, òf men laat de zaak er bij en het paar gaat zonder eenige betaling of restitutie van elkaar af.

Ofschoon de kinderen tot de wa la van de moeder behooren, 
zijn ze toch geheel het eigendom van den vader, wanneer de bruidsschat is afbetaald. Na den dood van den vader blijft de moeder met de kinderen dan ook bij de familie van haar overleden man. Zijn beide ouders overleden, dan komen de kinderen in huis bij een broer of zuster of een anderen bloedverwant van den vader. Eerst wanneer de verwanten van den vader niet in staat zijn voor de kinderen te zorgen, mag de familie van de moeder hen tot zich nemen.

Wanneer de vader overlijdt, deelen de zoons de erfenis. De dochters krijgen niets er van, maar zij moeten zoolang ze ongehuwd zijn door hare broers onderhouden worden. Zijn de kinderen nog klein, dan wordt de erfenis beheerd door hem die voor de kinderen zorgt.

De vader verdeelt dikwijls tijdens zijn leven zijn vee en zijne goederen onder zijne zoons, waarbij de oudste gewoonlijk het grootste aandeel krijgt. De jongeren krijgen dan ieder een even groot deel. De vader kan in deze echter geheel naar eigen goeddunken handelen. Hij kan een of meer zoons onterven, of zelfs den jongste boven den oudste bevoordeelen. Is bij den dood van den vader de bruidsschat nog niet voldaan, dan wordt deze uit de erfenis betaald, en het overschietende onder de kinderen verdeeld.

Indien de overledene geen zoons doch slechts dochters heeft achtergelaten, komt de erfenis aan de familie van den overledene. Dit gebeurt ook als de man kinderloos sterft. Eerst wanneer de vader geen familie heeft achtergelaten, wanneer hij dus een vreemdeling in het land is, vervalt de erfenis aan de weduwe.

Het beeld, dat wij uit het bovenstaande van het huwelijksstelsel in Kodi krijgen, verschilt dus nagenoeg niet van dat, wat ik van het overige Soemba heb geteekend. Al volgen de kinderen de wala van de moeder, het stelsel is toch volkomen vaderrechtelijk. In de positie van de vrouw in Kodi is dan ook geen verschil met die der vrouw in andere landschappen van Soemba. $\mathrm{Zij}$ heeft hier evenmin rechten als daar. 